\title{
Physiological factors could enhance amyloid-beta toxicity
}

\author{
Ph.D Thesis
}

Ákos Gábor Hunya

Department of Medical Chemistry

University of Szeged

Supervisor:

Dr. Zsolt László Datki

Szeged

2012. 
List of publications

Original full papers, directly related to the subject of the thesis:

I. A novel method for the rapid determination of beta-amyloid toxicity on acute hippocampal slices using MTT and LDH assays.

Mozes E, Hunya A, Posa A, Penke B, Datki Z.

Brain Res Bull. 2012 Apr 10;87(6):521-5 (IF : 2.818)

II.A novel application of the fluorescent dye bis-ANS for labeling neurons in acute brain slices.

Mozes E, Hunya A, Toth A, Ayaydin F, Penke B, Datki ZL.

Brain Res Bull. 2011 Oct 10;86(3-4):217-21 (IF : 2.818)

III.Differences between normal and alpha-synuclein overexpressing SH-SY5Y neuroblastoma cells after $\mathrm{A} \beta(\mathbf{1 - 4 2})$ and NAC treatment.

Hunya A, Földi I, Szegedi V, Soós K, Zarándi M, Szabó A, Zádori D, Penke B, Datki ZL. Brain Res Bull. 2008 Mar 28;75(5):648-54. (IF : 2.281)

IV.A novel and simple fluorescence method for the measurement of presynaptic vesicular zinc release in acute hippocampal slices with a fluorescence plate reader. Datki ZL, Hunya A, Penke B.

Brain Res Bull. 2007 Sep 14;74(1-3):183-7. (IF : 1.943) 
Manuscript in preparation:

I. Aging in Rats Promotes Alzheimer's Disease $\beta$-amyloid Aggregation and Toxicity by Metallostasis of Extraneuronal Zinc.

Zsolt L. Datki, Blaine R. Roberts, Akos Hunya, Adam Gunn, Eva Kondorosi, Paul A. Adlard, Viktor Szegedi, Gabor Juhasz, Dora Simon, Livia Fulop, Istvan Foldi, Zsolt Bozso, Katalin Soos, Gabor Kozma, Danny Hatters, Akos Kukovecz, Colin L. Masters, Ferhan Ayaydin, Zoltan Konya, Ashley I. Bush.

Original full papers, not directly related to the subject of the thesis:

I. Fibrillar A $\beta$ (1-42) enhances NMDA receptor sensitivity via the integrin signaling pathway. Juhász G, Barkóczi B, Vass G, Datki Z, Hunya A, Fülöp L, Budai D, Penke B, Szegedi V. J Alzheimers Dis. 2010;19(3):1055-67 (IF : 4.261)

II. Membrane-lipid therapy in operation: the Hsp co-inducer BGP-15 activates stress signal transduction pathways by remodeling plasma membrane rafts.

Gombos I, Crul T, Piotto S, Güngör B, Török Z, Balogh G, Péter M, Slotte JP, Campana F, Pilbat AM, Hunya A , Tóth N, Literati-Nagy Z, Vígh L Jr, Glatz A, Brameshuber M, Schütz GJ, Hevener A, Febbraio MA, Horváth I, Vígh L.

PLoS One. 2011;6(12):e28818. (IF : 4.092)

III. Hydroximic acid derivatives: pleiotrophic Hsp co-inducers restoring homeostasis and robustness.

Crul T, Toth N, Piotto S, Literati-Nagy P, Tory K, Haldimann P, Kalmar B, Greensmith L, Torok Z, Balogh G, Gombos I, Campana F, Concilio S, Gallyas F, Nagy G, Berente Z, Gungor B, Peter M, Glatz A, Hunya A, Literati-Nagy Z, Vigh L, Hoogstra-Berends F, Heeres A, Kuipers I, Loen L, Seerden JP, Zhang D, Meijering RA, Henning RH, Brundel BJ, Kampinga HH, Koranyi L, Szilvassy Z, Mandl J, Sumegi B, Febbraio MA, Horvath I, Hooper PL, Vigh L.

Curr Pharm Des. 2012 Aug 16. (IF : 3.87) 


\section{Abbreviations}

\begin{tabular}{|c|c|}
\hline$\alpha \mathrm{SN}$ & Alpha-synuclein protein \\
\hline $\mathrm{A} \beta$ & Amyloid-beta peptide \\
\hline ACSF & Artificial cerebrospinal fluid \\
\hline $\mathrm{AD}$ & Alzheimer's disease \\
\hline ADDLs & $\mathrm{A} \beta$-derived diffusible ligands \\
\hline APP & Amyloid precursor protein \\
\hline ASPD & Native-amylospheroids \\
\hline $\mathrm{BCA}$ & Bicinchoninic acid \\
\hline CDK5 & Cyclin-dependent kinase 5 \\
\hline DLBD & Diffuse Lewy body disease \\
\hline DMSO & Dimethyl-sulfoxide \\
\hline DNP & 2,4-dinitrophenol \\
\hline FBS & Fetal bovine serum \\
\hline fEPSP & Field excitatory postsynaptic potentials \\
\hline GSK-3 $\beta$ & Glycogen synthase kinase 3 beta \\
\hline HEPES & 4-(2-hydroxyethyl)-1-piperazineethanesulfonic acid \\
\hline LBD & Lewy body diseases \\
\hline LBV & Lewy body variant of Alzheimer's disease \\
\hline LDH & Lactate dehydrogenase \\
\hline LTP & Long-term potentiation \\
\hline MAP & Microtubule associated protein \\
\hline MEM & Minimal essential medium \\
\hline NAC & Non-amyloid component of Alzheimer's disease amyloid \\
\hline NACP & NAC precursor $=$ alpha-synuclein \\
\hline NFTs & Neurofibrillary tangles \\
\hline NMDA & $N$-methyl-D-aspartate \\
\hline NMDAR & $N$-methyl-D-aspartate receptor \\
\hline NR2B & Subunit of NMDAR \\
\hline PBS & Phosphate buffered saline \\
\hline PD & Parkinson's disease \\
\hline PI & Propidium iodide \\
\hline PP-1 & Protein phosphatase 1 \\
\hline PP-2A & Protein phosphatase $2 \mathrm{~A}$ \\
\hline RT & Room temperature \\
\hline SDS-PAGE & Sodium dodecyl sulphate-polyacrylamide gel electrophoresis \\
\hline SEM & Standard error of mean \\
\hline TBS & Theta-burst stimulation \\
\hline TEM & Transmission electron microscopy \\
\hline $\mathrm{upH}_{2} \mathrm{O}$ & MilliQ ultrapure water \\
\hline ZEN & Zinc-enriched neuron \\
\hline $\mathrm{ZnT}$ & Zinc transporter \\
\hline
\end{tabular}




\section{Table of contents}

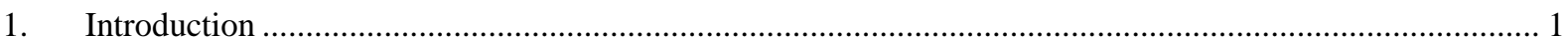

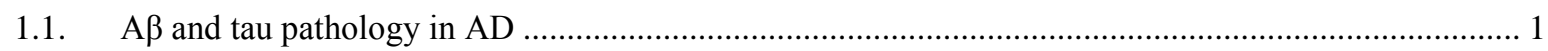

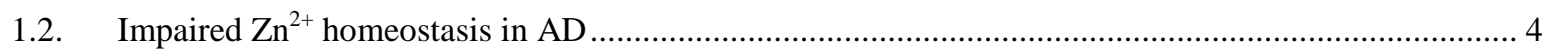

1.3. Aggregated $\alpha$-synuclein is associated with the development of $\mathrm{AD}$............................................ 7

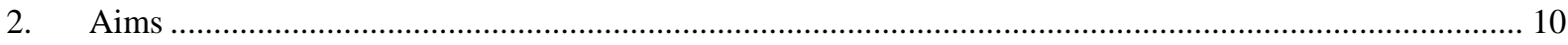

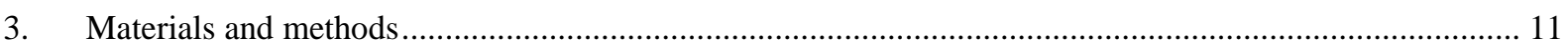

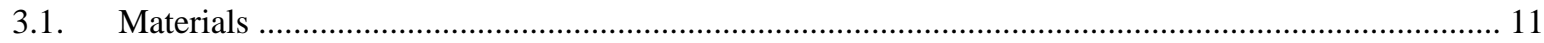

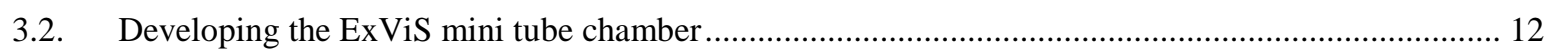

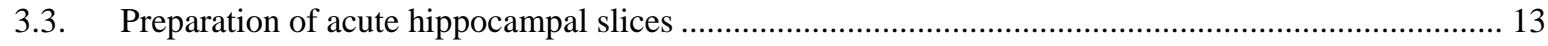

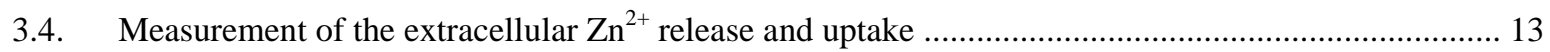

3.5. MTT mitochondrial reductase assay of hippocampal slices ...................................................... 14

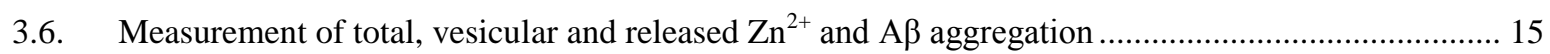

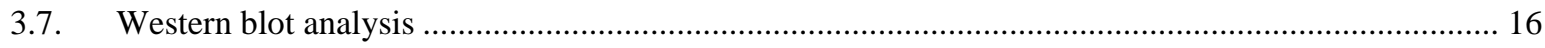

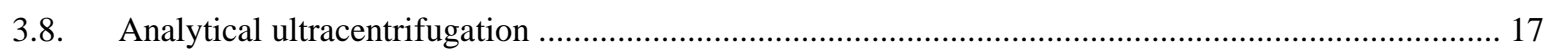

3.9. Multi-electrode array (MEA) electrophysiology .............................................................. 17

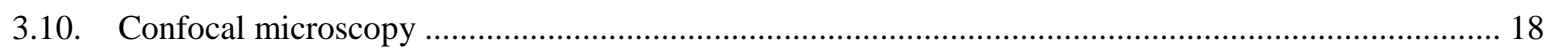

3.11. Treatments of differentiated $\alpha \mathrm{SN}$ normal and overexpressing cells ......................................... 19

3.12. MTT bioassay for $\alpha \mathrm{SN}$ normal and overexpressing cell culture ........................................................ 19

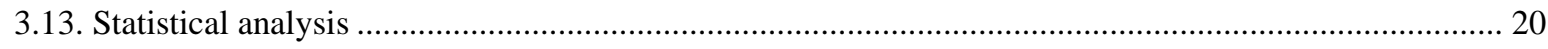

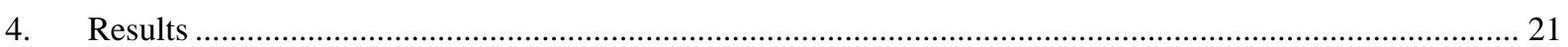

4.1. Experiments on the role of $\mathrm{Zn}^{2+}$ dishomeostasis in $\mathrm{A} \beta$ aggregation .......................................... 21

4.1.1. Activated hippocampal slices from aged rats release more zinc......................................... 21

4.1.2. Impaired reuptake of extracellular zinc by older hippocampal slices .................................. 23

4.1.3. $\mathrm{Zn}^{2+}$ from activated hippocampal slices induces $\mathrm{A} \beta(1-42)$ oligomerization............................. 26

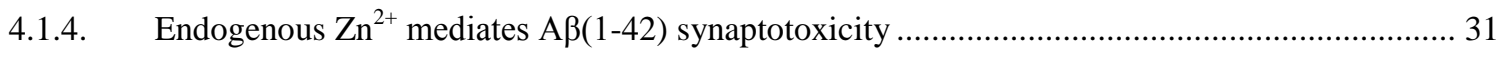

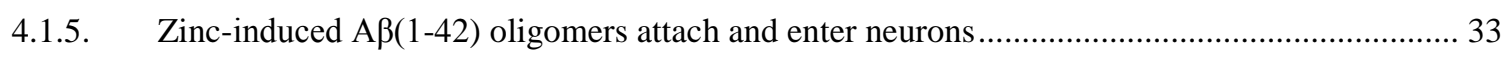

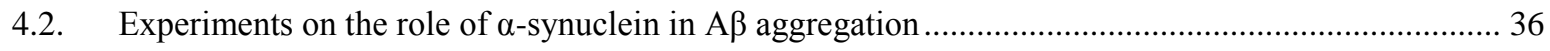

4.2.1. Phenotypic characterization of $\alpha \mathrm{SN}$ normal and overexpresing cell lines .................................. 36

4.2.2. Measurement of proliferation kinetics with MTT assay ................................................... 37

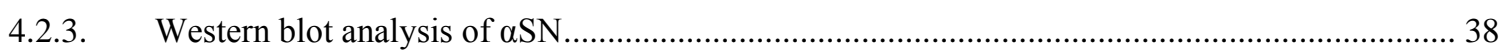

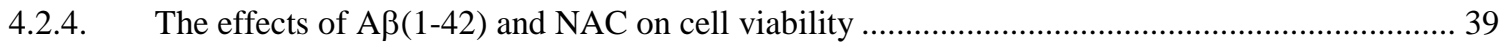

4.2.5. The effects of classical apoptotic factors on cell viability ................................................. 40

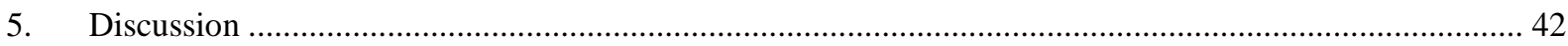

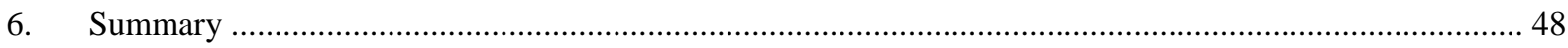

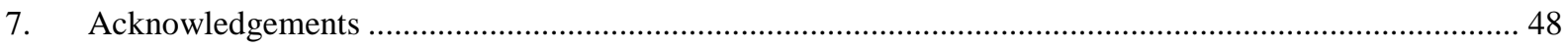

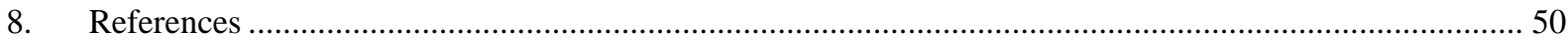




\section{Introduction}

Alzheimer's disease (AD) is a heterogeneous, progressive neurodegenerative disorder representing the most common cause of cognitive failure and dementia in older human patients. Extracellular deposition of beta amyloid peptide, intracellular formation of neurofibrillar tangles (NFT) caused by hyperphosphorylated tau protein and oxidative stress induced by impaired metabolic pathways and metals are the hallmarks of the disease (Bush, 2003, Gotz et al., 2004, Metcalfe and Figueiredo-Pereira, 2010, Obulesu and Rao, 2010). The primary theory for the cause of $\mathrm{AD}$ is the overproduction and/or impaired clearance of amyloid-beta $(\mathrm{A} \beta)$ peptides derived from amyloid precursor protein (APP), especially the markedly toxic 42 amino acid containing A $\beta$ (1-42) (Hardy and Selkoe, 2002, Mattson, 2004). The secondary hypothesis is the "metal hypothesis" which proposes the interaction of A $\beta$ with specific metal ions that could enhance $A \beta$ aggregation, pathogenicity and finally cause downstream AD pathology (Bush, 2003, Smith et al., 2007).

\subsection{A $\quad$ and tau pathology in AD}

Brain tissues of $\mathrm{AD}$ patients after autopsy contain two main characteristic lesions: extracellular amyloid plaques and intracellular neurofibrillary tangles which are formed by hyperphosphorylated tau protein (Goedert and Crowther, 1989, Selkoe, 2003). There are two main forms of amyloid depositions: senile (or neuritic) and diffuse plaques.

Senile plaques (originally observed by Alois Alzheimer) are extracellular spherical structures around 50-200 $\mu \mathrm{m}$ in diameter which contain a central amyloid core enriched in A $\beta$ peptides (Iwatsubo et al., 1994), and associated with axonal and dendritic injury, usually localized in abundance in the limbic and association cortices (Dickson, 1997). The A $\beta$ peptides form extracellular aggregates that mainly appear in a filamentous form, as starshaped masses of amyloid fibrils. These amyloid fibrils are containing particularly two A $\beta$ species: the 40 amino acid containing $A \beta(1-40)$ and the 42 amino acid containing $A \beta(1-42)$. $\mathrm{A} \beta(1-40)$ is more abundantly produced by neurons but less prone to aggregation and is not so hydrophobic, as the slightly longer A $\beta(1-42)$ (Jarrett et al., 1993). Moreover, these kinds of 
plaques contain dystrophic neurons (both within the plaques and directly surrounding it), reactive microglia, lipofuscin, tau protein etc.

Diffuse plaques (or "pre-amyloid deposits") are amorphous, roughly spherical aggregates which were observed in the late 1980s (Tagliavini et al., 1988, Yamaguchi et al., 1988, Joachim et al., 1989). In diffuse plaques, A $\beta$ exists as non-amyloid aggregates (Tagliavini et al., 1993) that cannot be labeled by fibrillum specific indicators (e.g. Congo Red and thioflavin-S, which are able to indicate cross- $\beta$-pleated-sheets) and do not contain dying or damaged neurons. They might be present in relatively high number in normal aged individuals. The major component of such deposits is the $A \beta(1-42)$, with little or no $A \beta(1-40)$ immunoreactivity, in contrast to the fibril-rich senile plaques which are comprising both $\mathrm{A} \beta(1-42)$ and $A \beta(1-40)$ aggregates co-localized (Gowing et al., 1994, Iwatsubo et al., 1994, Iwatsubo et al., 1995, Lemere et al., 1996). Whether these pre-amyloid deposits are the precursors of fibrillogenesis and senile plaques formation or represent products of alternate aggregation pathway is still under extensive research.

A $\beta$ is derived from the post-translational proteolysis of APP (Kang et al., 1987). APP is a ubiquitously expressed type I membrane-spanning glycoprotein (Kang et al., 1987) and it is encoded by a single gene on chromosome 21q21.3 (Goldgaber et al., 1987, Robakis et al., 1987, Jenkins et al., 1988, Patterson et al., 1988, Korenberg et al., 1989). The A $\beta$ peptide sequence is localized partially in the extracellular-, and partially in the membrane domain of APP. The proteolytic cleavage of APP by three proteases, i.e. $\alpha$-, $\beta$ - and $\gamma$-secretase takes place in two ways. Cleavage of APP by either $\alpha$ - or $\beta$-secretases produces large soluble Nterminal fragments: $\mathrm{sAPP}_{\alpha}$ or $\mathrm{sAPP}_{\beta}$ and membrane-associated C-terminal fragments $\mathrm{CTF}_{\alpha}$ and $\mathrm{CTF}_{\beta}$, respectively. Both C-terminal fragments will further be cleaved by the $\gamma$-secretase within the transmembrane domain producing the non-pathogenic p3 peptide or A $\beta$. The cleavage done by $\alpha$-secretase prevents $A \beta$ production, therefore it is called the nonamyloidogenic pathway. In contrast, $\beta$-secretase-mediated APP cleavage generates A $\beta$, most often $A \beta(1-40)$ and $A \beta(1-42)$ peptides, hence it is called the amyloidogenic pathway (Guo et al., 2011). In physiological conditions, $A \beta$ present in the brain tissue is degraded by metalloproteinases such as insulin-degrading enzyme (insulysin), neprilysin, and by endothelin-converting enzyme (Carson and Turner, 2002). The generally accepted hypothesis for the development and cause of $\mathrm{AD}$ is the amyloid cascade hypothesis (Fig. 1.). According 
to the hypothesis the imbalance between the production and clearance of $A \beta$ in the brain is the earliest event in the development of $\mathrm{AD}$, ultimately leading to neuronal degeneration and dementia (Hardy and Allsop, 1991, Hardy and Selkoe, 2002). A conformational change occurs in the soluble $A \beta$ monomer, precisely there is an increase in $\beta$-sheet content and therefore the aggregation ability of $A \beta$ will be also increasing. $A \beta(1-42)$ can even trigger the misfolding of another A $\beta$ species (Jarrett et al., 1993). These altered monomers may not only form soluble oligomers, but large insoluble fibrils too, which are the main component of neuritic plaques. Only $\mathrm{A} \beta$ fibrils deposited in plaques were previously thought to be neurotoxic, however, recent findings have revealed that soluble $\mathrm{A} \beta$ oligomers could inhibit long-term potentiation (LTP), disrupt synaptic plasticity and ultimately cause neuronal cell death (Walsh et al., 2002).

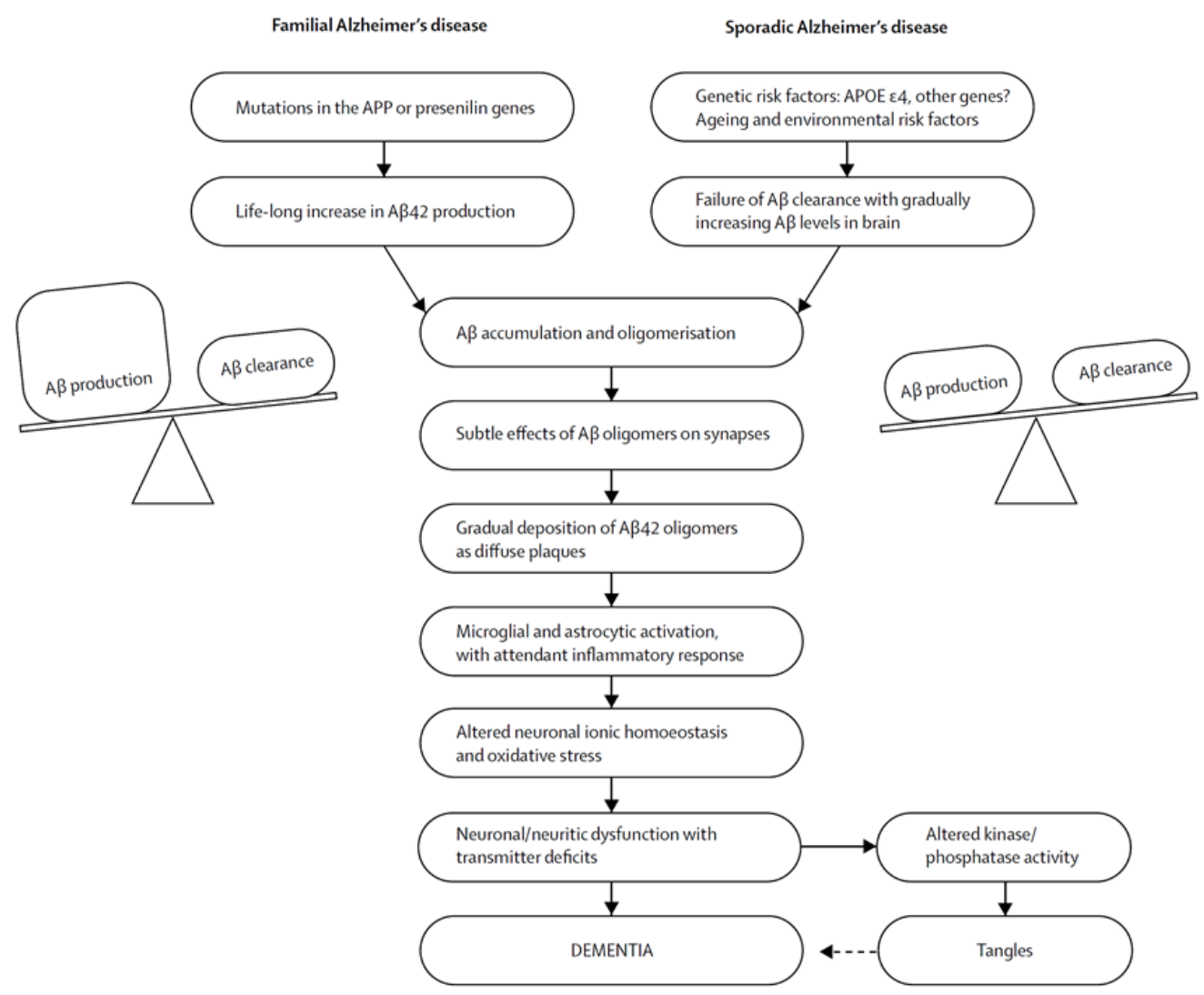

Figure 1. The amyloid cascade hypothesis. It suggests, that the main event of the disease pathogenesis is an imbalance between $A \beta$ production and clearance, namely the production of $A \beta$ is increasing in familial form of $A D$, and the clearance of $A \beta$ is disrupted in case of sporadic $A D . A \beta$ accumulation and aggregation will directly or indirectly cause a list of negative effects e.g. LTP 
inhibition, disruption of synaptic function, neuronal cell death, inflammation etc., which ultimately leads to cognitive decline. Tau pathology and NFT formation is considered as a subsequent event, but it has a major effect on the neuronal dysfunction and the development of the disease (Blennow et al., 2006).

The most characteristic hallmark of AD beside the amyloid aggregates are the NFTs which are assembled from hypherphosphorylated tau protein (Grundke-Iqbal et al., 1986, Nukina and Ihara, 1986). Tau is a microtubule-associated protein (MAP); through its binding domains it regulates the assembly and stability of the microtubules. The phosphorylation of tau protein is rather strictly regulated by a couple of kinases (e.g. GSK-3 $\beta$ and CDK5) and phosphatases (e.g. PP-1 and PP-2A) (Iqbal et al., 2005). If hyperphosphorylation or abnormal phosphorylation occurs, tau protein and other MAPs lose their ability to bind and stabilize the microtubules, which has a lot of downstream effect (e.g. disassembly of microtubules, disrupted axonal transport etc.) and finally lead to neuronal dystrophy (Iqbal et al., 2005). Tau protein also has a propensity for aggregation into insoluble fibrils in tangles, which are intracellular depositions and are also harmful for neurons. Tau pathology is an early event in $\mathrm{AD}$ pathomechanism and it initializes in the transentorhinal cortex, spreads to hippocampal area and amygdala, and later to the neocortical association areas (Braak et al., 1999). Whether tau hyperphosphorylation and NFT formation are a cause or consequence of AD remains elusive.

\subsection{Impaired $\mathrm{Zn}^{2+}$ homeostasis in $\mathrm{AD}$}

The zinc ion $\left(\mathrm{Zn}^{2+}\right)$ has an essential function in numerous biochemical processes, as a co-factor of more than 300 proteins or enzymes that affect many aspects of cellular metabolism, involving metabolism of proteins, lipids and carbohydrates (Bettger and O'Dell, 1981, Parkin, 2004, Mocchegiani et al., 2005). $\mathrm{Zn}^{2+}$ is responsible for the conformational stabilization in several transcription factors (Rebar and Pabo, 1994, Elrod-Erickson et al., 1998) and also modulates cellular signal transduction processes (Besser et al., 2009, Chorin et

al., 2011). $\mathrm{Zn}^{2+}$ is a small (0.65Á), redox-inert ion (Bettger and O'Dell, 1981, Qian and Noebels, 2006), which binds mostly to nitrogen and sulphur atoms and ligands. It has 
relatively low ligand field stabilization energy, therefore its exchange between ligands is quite easy (Williams, 1989). The brain has the highest zinc content compared to other organs. There are also big differences regarding the distribution of $\mathrm{Zn}^{2+}$ in distinct brain areas, high concentrations of $\mathrm{Zn}^{2+}$ is detectable in hippocampus, cerebellum, amygdala and neocortex (Frederickson et al., 2000). Almost all ( 95\%) $\mathrm{Zn}^{2+}$ present in the mammalian tissues trapped within proteins or bound to zinc sequestering proteins (e.g. metallothioneins), although in the brain there is a pool localized within synaptic vesicles. Neurons which contain $\mathrm{Zn}^{2+}$ at high concentrations in the synaptic terminals are called zinc-enriched (ZEN) neurons (Frederickson et al., 2000, Wang et al., 2001). Cellular zinc homeostasis is partially regulated by two specific zinc transporter protein families, namely $\mathrm{ZnT}$ proteins and Zip proteins (Liuzzi and Cousins, 2004). ZnTs decrease cytoplasmic $\mathrm{Zn}^{2+}$ concentration by promoting zinc efflux from cells or vesicular zinc uptake, while Zip proteins raise cytoplasmic $\mathrm{Zn}^{2+}$ by facilitating extracellular and probably vesicular zinc transport into neurons and glial cells (Law et al., 2003, Liuzzi and Cousins, 2004, Seve et al., 2004).

Chelatable $\mathrm{Zn}^{2+}$ detection and tracing is quite easy using fluorescent probes (e.g. RhodZin-3, FluoZin-3, Newport Green, ZnAF-2, TFLZn etc.). During heat (or other environmental) stress response $\mathrm{Zn}^{2+}$ ions are released from metallothioneins (Pirev et al., 2010), resulting the increase of intracellular $\mathrm{Zn}^{2+}$ concentration. Moreover, depolarization during neurotransmission or evoked artificially by electric stimulation (Howell et al., 1984, Aniksztejn et al., 1987), by administration of $\mathrm{K}^{+}$(Assaf and Chung, 1984, Charton et al., 1985, Aniksztejn et al., 1987) or by kainic acid (Assaf and Chung, 1984, Charton et al., 1985) cause the release of $\mathrm{Zn}^{2+}$ from hippocampal neuronal terminals into the synaptic cleft (Aniksztejn et al., 1987), thus extracellular $\mathrm{Zn}^{2+}$ concentration raises. In physiological concentrations $\mathrm{Zn}^{2+}$ shows neuroprotective activity, although high concentrations of $\mathrm{Zn}^{2+}$ are neurotoxic (Bancila et al., 2004, Cote et al., 2005). Recent reports demonstrate the critical role of $\mathrm{Zn}^{2+}$ availability in the memory function, learning, neurogenesis etc., however marked changes in physiological $\mathrm{Zn}^{2+}$ levels in the brain may be a risk factor of neurological diseases such as Alzheimer's disease (Bush et al., 1994b, Mocchegiani et al., 2005, Bitanihirwe and Cunningham, 2009, Sensi et al., 2009, Suh et al., 2009, Takeda and Tamano, 2009).

Increasing body of evidence indicates that neuronal $\mathrm{Zn}^{2+}$ release plays an important role in $\mathrm{A} \beta$ deposition in $\mathrm{AD}$. $\mathrm{A} \beta$ is rapidly precipitated by $\mathrm{Zn}^{2+}$ at neutral $\mathrm{pH}$ (Bush et al., 
1994b). A $\beta$ within plaques directly binds $\mathrm{Zn}^{2+}$ (Opazo et al., 2002, Dong et al., 2003), which could explain the phenomenon that amyloid plaques are heavily enriched with $\mathrm{Zn}^{2+}$ in humans (Lovell et al., 1998, Cherny et al., 1999, Miller et al., 2006) and APP transgenic mice (Lee et al., 1999, Stoltenberg et al., 2007). $\mathrm{Zn}^{2+}$-induced $\mathrm{A} \beta$ aggregation is reversible with chelators, such as EDTA and clioquinol; and $\mathrm{A} \beta$ deposits in human brain are dissolved with metal chelators that liberate $\mathrm{Zn}^{2+}$ (Cherny et al., 1999, Cherny et al., 2001).

The $\mathrm{Zn}^{2+}$ that aggregates $\mathrm{A} \beta$ in vivo is released from synaptic vesicles of glutamatergic neurons during neurotransmission reaching an extracellular concentration of $300 \mu \mathrm{M}$ (Frederickson et al., 2006). It is normally transferred into glutamatergic presynaptic vesicles by the activity of $\mathrm{ZnT3}$, a transmembrane protein which expression overlaps with brain regions where amyloid depositions are the most frequent (Palmiter et al., 1996, Stoltenberg et al., 2007). ZnT3 is concentrated in dystrophic neurites in amyloid plaques (Stoltenberg et al., 2007), and the knockdown of ZnT3 gene is markedly inhibits amyloid pathology in APP transgenic mice (Lee et al., 2002, Friedlich et al., 2004).

Increased age and female gender are the major risk factors for $A D$, and both cause $A \beta$ accumulation in humans and APP transgenic mice by unclear mechanisms (Davies et al., 1988, Callahan et al., 2001). While ZnT3 expression is elevated in female mouse brain, and knockdown of ZnT3 gene suppresses the excessive A $\beta$ deposition in female APP transgenic mice (Lee et al., 2002, Lee et al., 2004), the mechanisms for these effects (e.g. affecting uptake or release of zinc) remains elusive. However, recent work has shown that $A \beta$ 1-42 oligomers attach to the NR2B subunit of the NMDA receptor of wild-type but not ZnT3-/hippocampal slices, in an activity-dependent manner (Deshpande et al., 2009).

The reasons for extracellular $\mathrm{Zn}^{2+}$ precipitation of $\mathrm{A} \beta$ with age, when both are constitutively released with synaptic activity (Lazarov et al., 2002, Frederickson et al., 2006, Cirrito et al., 2008), are unresolved. We utilized acute hippocampal slices to model $\mathrm{Zn}^{2+}$ release throughout the neocortex (since ZnT3 is expressed in both area)), and to study changes that occur with age and gender that may explain how these risk factors affect Alzheimer pathology. 


\subsection{Aggregated $\alpha$-synuclein is associated with the development of AD}

The depositions of $\alpha$-synuclein (also known as: NAC precursor, NACP) protein $(\alpha \mathrm{SN})$, are the pathological hallmarks of the so called "Lewy body diseases" (LBD). The $\alpha \mathrm{SN}$ protein is made of 140 amino acid residues and its sequence has been well conserved among vertebrates (Maroteaux et al., 1988, Buchman et al., 1998). The normal physiological function(s) of $\alpha \mathrm{SN}$ has not been precisely defined yet, but mutations in $\alpha \mathrm{SN}$ have been associated with the dominantly inherited familial forms of Parkinson's disease (PD) (Polymeropoulos et al., 1997, Spillantini et al., 1998, Kruger et al., 1999). aSN, the protein which is localized mainly at the synaptic terminals (Shibayama-Imazu et al., 1993, Iwai et al., 1995) is also involved in neural membrane trafficking (Outeiro and Lindquist, 2003), it may control the vesicle formation and helps their maintenance (Iwai et al., 1995, Jensen et al., 1998). It is also suggested, that $\alpha \mathrm{SN}$ directly interacts with biological membranes and modulates the synaptic vesicle release cycle (Burre et al., 2010, Gaugler et al., 2012, Kuwahara et al., 2012). Overproduction of $\alpha$ SN causes plenty of negative intracellular events e.g. damage of the ER-Golgi trafficking (Cooper et al., 2006, Thayanidhi et al., 2010), fragmentation of the Golgi apparatus (Gosavi et al., 2002) and mitochondrial membrane injuries (Song et al., 2004).

LBD has three subtypes: the Parkinson's disease, the diffuse Lewy body disease (DLBD), and also the Lewy body variant of Alzheimer's disease (LBV) (Lewis et al., 2010). This fact clearly points out that there should be a close connection between the pathogenesis of the two most frequent neurodegenerative diseases, namely AD and PD (Fig. 2). 


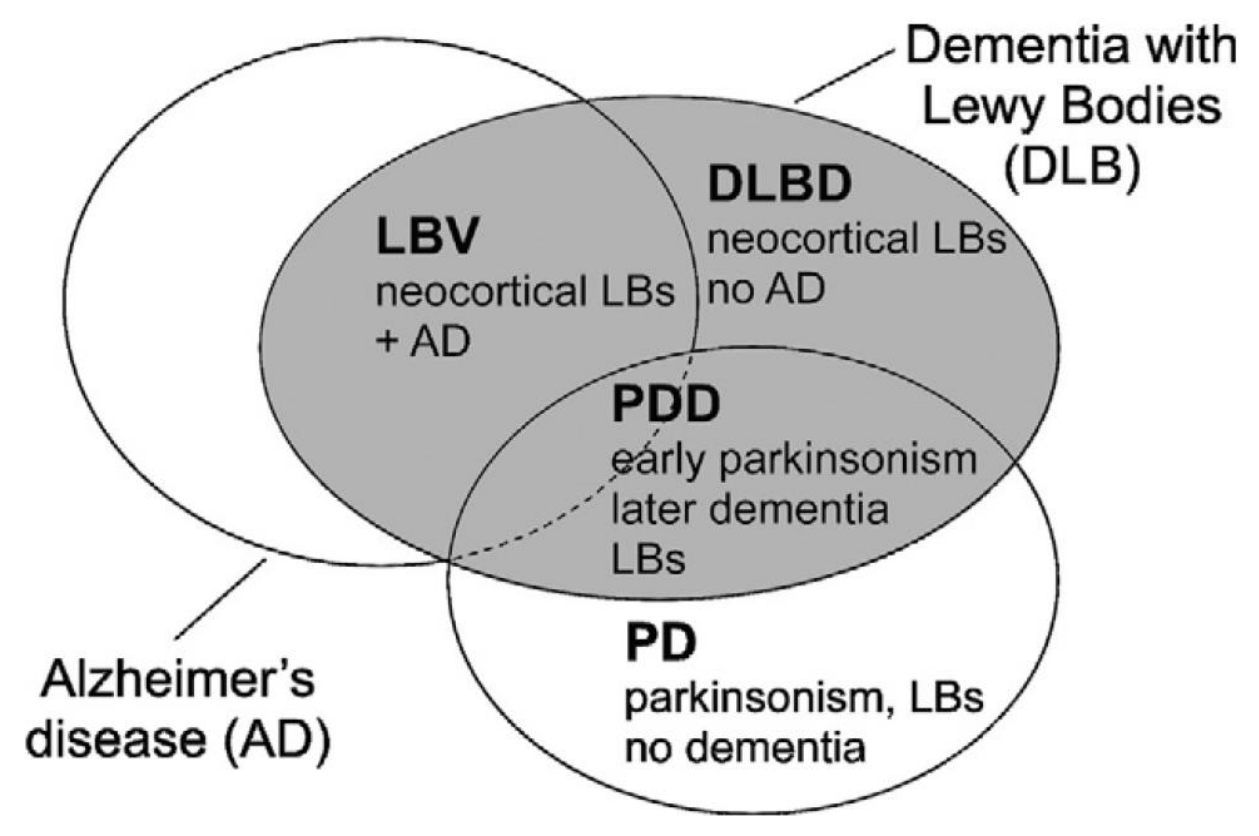

Figure 2. Relatively high overlap between Alzheimer's disease (AD) and dementia with Lewy bodies (DLB). PD, Parkinson's disease; LBV, Lewy body variant of Alzheimer's disease; DLBD, diffuse Lewy body disease; PD, Parkinson's disease; PDD, Parkinson's disease dementia; LBs, Lewy bodies (Lewis et al., 2010).

The premise, that $\alpha \mathrm{SN}$ is somehow playing a role in the pathogenesis of $\mathrm{AD}$ is not novel. However, there is a rather big contradiction in the literature about the interaction of $\alpha \mathrm{SN}$ and $\mathrm{A} \beta$. First time in 1993 Ueda and co-workers revealed that the 61-95 residues of $\alpha \mathrm{SN}$, the so called NAC (non-amyloid component of Alzheimer's disease amyloid) domain is present in senile plaques of human AD cortex (Ueda et al., 1993). Two years later, based on the work of Yoshimoto and colleagues it seemed that NAC is able to bind to the 25-35 residues of the $A \beta$ (1-40) and $A \beta$ (1-42) peptides, which are the major components of $A D$ amyloid plaques (Yoshimoto et al., 1995). On the other hand, results of other research groups confirmed that there is no direct physical interaction between NAC and $\mathrm{A} \beta$ peptides and NAC is not present in A $\beta$ deposits (Bayer et al., 1999, Culvenor et al., 1999), although NAC was found in abundance in dystrophic neurons which are surrounding the senile plaques (Culvenor et al., 1999). However, most researchers agree on that the appearance of aggregated A $\beta$ may significantly exacerbate the process of LBD (Pletnikova et al., 2005). In the same way if the 
aggregating $\alpha \mathrm{SN}$ is present it could accelerate the development of $\mathrm{AD}$. Recent studies revealed certain interactions in vitro that stimulate cross-fibrillization between $\alpha \mathrm{SN}$ and $\mathrm{A} \beta$, and between $\alpha \mathrm{SN}$ and tau protein stimulating and accelerating each other's aggregation (Giasson et al., 2003, Geddes, 2005, Mamah et al., 2005). Consequently, there is "cross-talk" among neurodegenerative disorders and the stronger this connection is the more severe the disease. Realizing these unexplored interactions between $\alpha \mathrm{SN}$ and $\mathrm{A} \beta$ / tau took us to the idea to use an $\alpha \mathrm{SN}$ overexpressing SH-SY5Y neuroblastoma cell line in AD research experiments. We investigated the effects of aggregated neurodegenerative disease-related peptides and classical apoptotic stressors on $\alpha \mathrm{SN}$ overexpressing cell line. Our results showed that the $\alpha \mathrm{SN}$ overexpressing cell line was more sensitive to the treatment of aggregated beta-amyloid (A $\beta$ 1-42) or NAC, but less sensitive to the classical apoptotic agents compared to the wild type SH-SY5Y neuroblastoma cell line. 


\section{Aims}

Although the precise role of $\mathrm{A} \beta$ in $\mathrm{AD}$ pathogenesis remains inconclusive, aggregation of this peptide seems to be the key in the development of the disease. Thus, investigating distinct physiological factors which could intensify the aggregation propensity and thereby the toxic effect of $A \beta$, would be very useful from the aspect of elaborating further anti-AD strategies.

The aggregation of extracellular $A \beta$ is taking place in the synaptic cleft which yields synaptotoxic oligomers. This phenomenon affects mostly the hippocampus, in which the main cell mass $(\sim 80 \%)$ is composed of $\mathrm{Zn}^{2+}$ containing glutamatergic principal neurons. During neurotransmission these neurons release vesicular $\mathrm{Zn}^{2+}$ into the synaptic cleft, where $\mathrm{Zn}^{2+}$ can precipitate $A \beta$. Moreover, according to the literature data $A \beta$ depositions are enriched with $\mathrm{Zn}^{2+}$, therefore it would be very important to investigate the effect of endogenous extracellular $\mathrm{Zn}^{2+}$ to $\mathrm{A} \beta$ aggregation.

Recent findings have revealed that there are a close relationship between AD and PD; $\mathrm{A} \beta$ may interact with $\alpha \mathrm{SN}$, therefore it should be reasonable, to study $\mathrm{A} \beta$ and $\alpha \mathrm{SN}$ simultaneously.

In the course of my Ph.D. work I attained the following aims:

1. Examining different extrinsic factors, which can enhance $A \beta$ toxicity and aggregation via synergistic way.

1.1. Explore whether endogenous vesicular $\mathrm{Zn}^{2+}$ could be able to precipitate and subsequently intensify the neurotoxic effect of exogenous $A \beta$ (synergistic effect of peptide - metal).

1.2. Investigating $\mathrm{A} \beta$ and $\alpha \mathrm{SN}$ interactions and their boosting effect to each other's aggregation (synergistic effect of peptide - protein).

2. For the fast and effective measurements it was essential to develop two methods:

2.1. A novel method for maintaining and even treating acute hippocampal slices in small working volume (ExViS).

2.2. A novel method for fluorescent detection of $A \beta$ precipitation in acute hippocampal slices. 


\section{Materials and methods}

\subsection{Materials}

Cell impermeant forms of RhodZin-3, FluoZin-3 and Newport Green were from Molecular Probes, Invitrogen, (Budapest, Hungary). ZnAF-2, TFLZn, 4,4(')-dianilino-1,1(')binaphthyl-5,5(')-disulfonate dipotassium salt (Bis-ANS), Thioflavine T, N,N,N',N'tetrakis(2-pyridylmethyl)ethylenediamine (TPEN), calcium ethylenediaminetetraacetic acid (CaEDTA), 2,4-dinitrophenol (DNP), propidium iodide (PI) pyrithione, chloral hydrate, 3(4,5-Dimethylthiazol-2-yl)-2,5-diphenyltetrazolium bromide (MTT), dimethyl-sulfoxide (DMSO), bovine serum albumin (BSA), all-trans retinoic acid (RA), 12-O-tetradecanoylphorbol-13-acetate (TPA), hydrogen peroxide $\left(\mathrm{H}_{2} \mathrm{O}_{2}\right)$, amphotericin $\mathrm{B}$, ruthenium red, Triton $\mathrm{X}-100$, Tween 20 , protease inhibitor cocktail, polyclonal anti- $\alpha \mathrm{SN}$ antibody produced in rabbit, and mouse anti- $\beta$-tubulin monoclonal antibody, lactate dehydrogenase assay kit (LDH kit), 96-well plates, and general reagents were from Sigma-Aldrich, (Budapest, Hungary). Fetal bovine serum (FBS), phosphate buffered saline (PBS), L-glutamine, penicillinstreptomycin, and MEM non-essential amino acids were purchased from Gibco, Invitrogen (Budapest, Hungary), 96-well plates from Nunc (Roskilde, Denmark), peroxidase-conjugated goat anti-rabbit IgG antibody from Dako (Glostrup, Denmark), anti-TrkB antiserum from Cell Signaling Technologies (Budapest, Hungary) chemiluminescent substrate of peroxidase from Pierce (Rockford, IL, USA), and bicinchoninic acid (BCA) assay kit from Novagen (Madison, WI, USA). For all experiments which require distilled water, MilliQ ultrapure water $\left(\mathrm{upH}_{2} \mathrm{O}\right)$ was used. The ExViS mini-chamber system was made in-house at BAYGEN (Szeged). The animal protocols applied in this study had been approved by the National Institute of Health and by the University of Szeged; permission number: I-02442/001/2006. Three types of synthetic $A \beta(1-42)$ were used: normal $A \beta(1-42)$ (solid phase synthesis; Zarandi et al., 2007) applied for $\alpha \mathrm{SN}$ overexpressing cell line studies, iso-A $\beta(1-42)$ (Bozso et al., 2010) and $\mathrm{A} \beta_{\triangle 2 \mathrm{His}}$ (synthesis proceeded as by iso- $\mathrm{A} \beta(1-42)$ with histidine residues at positions 13 and 14 replaced with Ala) used for $\mathrm{Zn}^{2+}-\mathrm{A} \beta$ precipitation experiments, were synthesized in our laboratory at the Department of Medical Chemistry, University of Szeged, Hungary. 


\subsection{Developing the ExViS mini tube chamber}

Most of the $\mathrm{A} \beta-\mathrm{Zn}^{2+}$ precipitation experiments were performed using an ex vivo model, namely acute hippocampal slices (section 3.3). For those experiments we needed equipment that is able to maintain the tissue slices without decreasing their viability and allow treatment with $A \beta$ (or other agents) in small working volume. To satisfy these claims, we developed the ExViS device.

ExViS is a novel floating incubation system using very small amount of incubation volume (1 $\mathrm{ml})$. Simultaneously, the system should provide optimal conditions (microenvironment) for the tissue slices $\left(\mathrm{O}_{2}, \mathrm{CO}_{2}, \mathrm{pH}\right.$, glucose, etc.). Application of carbogen (95\% $\mathrm{O}_{2}, 5 \% \mathrm{CO}_{2}$ ) gas current (bubbling) instead of perfusion was designed to avoid adsorption and precipitation of substances (e.g. $\beta$-amyloid peptide) in the circulating system. Floating the tissue slices instead of mechanical fixation minimizes tissue damage. The novel floating chamber provides simultaneous incubation for several slices in the same chamber to be able to run parallel experiments for statistical evaluation. The scaled drawing of ExViS mini tube chamber can be seen in Figure 3.

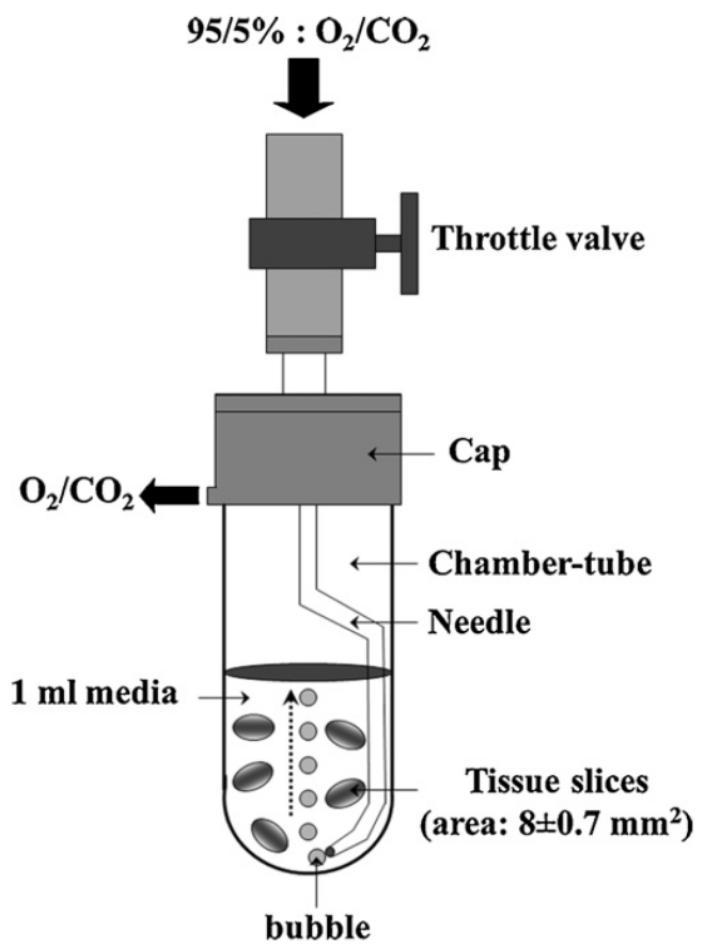

Figure 3. Schematic structure of ExViS mini tube chamber. 


\subsection{Preparation of acute hippocampal slices}

A modified version of the method reported by (Datki et al., 2007) was used. After anesthesia with chloral hydrate $(0.4 \mathrm{~g} / \mathrm{kg}), 10 \pm 1$ and $65 \pm 4$-weeks-old male and female Wistar rats were decapitated and the whole heads (without scalp) were put into ice-cold $\mathrm{upH}_{2} \mathrm{O}$ for $1 \mathrm{~min}$. The brains were quickly removed and immersed in $\mathrm{Ca}^{2+}$ free ACSF with elevated $\mathrm{Mg}^{2+}$ at $4^{\circ} \mathrm{C}$ (Lipton et al., 1995). Brain slices (thickness $400 \mu \mathrm{m}$ ) were prepared from the hippocampus with a McIlwain tissue chopper at $4{ }^{\circ} \mathrm{C}$. The surface area of the slices was determined with a dissecting microscope (type Nikon SMZ800 with a 12 megapixel camera) directly after preparation. The well area $\left(15 \mathrm{~mm}^{2}\right)$ was used for area calibration. The slices (area $\approx 9 \mathrm{~mm}^{2}$ ) were rapidly transferred into the ExViS mini-chamber (maximum 10 slices in $1 \mathrm{ml}$ ) for conditioning (30 $\mathrm{min}$ ) in carbogenated $\mathrm{Ca}^{2+}$-free ACSF preparation solution at room temperature $\left(23{ }^{\circ} \mathrm{C}\right)$. During this period the amount of $\mathrm{LDH}$ released into the $\mathrm{Ca}^{2+}$ free ACSF was assayed by LDH kit as an index of cytosolic release caused by mechanical trauma.

The slices were kept oxygenated by saturating bubbling carbogen into every buffer. The only time that there was not constantly bubbling carbogen present was during the last step of the actual experiment (e.g. treatment with high $\mathrm{K}^{+}$). Following that the slices were transferred to the multiwell format, which contained carbogen-saturated buffer.

The results from female rats were reproducible when performed at intervals of one or two weeks apart, indicating that stage of estrus did not influence the results.

\subsection{Measurement of the extracellular $\mathrm{Zn}^{2+}$ release and uptake}

After preparation, the hippocampal slices were incubated in carbogenated (actively bubbling in the ExViS chamber) Ca-free ACSF (in mM: $\mathrm{NaCl} 127, \mathrm{KCl} 2, \mathrm{MgCl}_{2} 5, \mathrm{NaHCO}_{3}$ 25, D-glucose 10, $\mathrm{pH}=7.4)$ while loaded with Zinquin (30 $\mu \mathrm{M}, 25 \mathrm{~min})$. The slices were then washed for $5 \mathrm{~min}$ in dye-free, actively carbogenated, Ca-free ACSF $(1 \mathrm{ml})$, and the slices then placed in a multi-well plate. $\mathrm{H}$-ACSF (composition in mM: $\mathrm{NaCl} 115, \mathrm{KCl} 3 ; \mathrm{CaCl}_{2} 2, \mathrm{MgCl}_{2}$ 2, $\mathrm{NaHCO}_{3}$ 10, HEPES 25, D-glucose 12, $\mathrm{pH}=7.4 ; 40 \mu \mathrm{l} /$ well) supplemented with RhodZin-3 
or ZnAF2 $(10 \mu \mathrm{M})$ was then added and kinetic measurements were taken by plate-reader. H-ACSF was utilized for fluorescent assay experiments since fluorophores are sensitive to $\mathrm{pH}$, and the additional HEPES helped maintain $\mathrm{pH}$ stability. Release and uptake studies were performed at $36{ }^{\circ} \mathrm{C}$, which was reported to be optimal for $\mathrm{Zn}^{2+}$ release (Frederickson et al., 2006).

In some experiments, $\mathrm{Zn}^{2+}$ uptake into slices was measured over a period (10 minutes) that required continuous oxygenation. To accomplish this we sampled and assayed the overlying incubation media at intervals. Ten slices together in each ExViS chamber were treated \pm DNP $(0.3 \mathrm{mM})$ or pyrithione $(50 \mu \mathrm{M})$ for $30 \mathrm{~min}$ in actively-carbogenated $\mathrm{Ca}^{2+}$-free ACSF at room temperature. The media were then changed to normal, actively carbogenated H-ACSF (composition in mM: $\mathrm{NaCl} 125, \mathrm{KCl} 2, \mathrm{CaCl}_{2} 2, \mathrm{MgCl}_{2} 2, \mathrm{NaHCO}_{3} 25$, D-glucose 12 , pH 7.4; $\left.15 \mathrm{ml}, 36^{\circ} \mathrm{C}\right) \pm \mathrm{DNP}$ or pyrithione, supplemented with $2 \mu \mathrm{M} \mathrm{ZnSO}_{4}$. We then sampled $(0.15 \mathrm{ml})$ the $\mathrm{Zn}^{2+}$ - containing $\mathrm{H}$-ACSF media from the same chamber at $30 \mathrm{~s}$ and 10 min. The remaining $\mathrm{Zn}^{2+}$ in the samples was assayed by adding RhodZin-3 and ZnAF2 (both to $10 \mu \mathrm{M})$. DNP did not alter the background fluorescent signal of the $\mathrm{Zn}^{2+}$ detection reagents. Pyrithione $50 \mu \mathrm{M}$ quenched $\approx 5 \%(\approx 100 \mathrm{nM})$ of the total $\mathrm{ZnAF} 2$ fluorescence of $2 \mu \mathrm{M} \mathrm{Zn}{ }^{2+}$ in H-ACSF, but had no significant effect on RhodZin-3 fluorescence in the same solution.

To study the effects of $\mathrm{A} \beta$ on $\mathrm{Zn}^{2+}$ uptake, following the slice preparation and loading with Zinquin we substituted the Ca-free ACSF wash step with an incubation in normal carbogenated ACSF supplemented with A $1-42(50 \mu \mathrm{M}, 10 \mathrm{~min})$, after that the slices were washed with H-ACSF, and placed into wells for treatment with $50 \mathrm{mM} \mathrm{KCl}$.

\subsection{MTT mitochondrial reductase assay of hippocampal slices}

Acute hippocampal slices were treated \pm different $A \beta$ forms in actively carbogenated $\mathrm{ACSF}$ at $36{ }^{\circ} \mathrm{C}\left(\mathrm{A} \beta\right.$ or $\left.\mathrm{A} \beta_{\Delta 2 \mathrm{His}}, 15 \mu \mathrm{M}\right)$ in ExViS chambers for $10 \mathrm{~min}$. Then the concentrations of either $\mathrm{KCl}$ or $\mathrm{NaCl}$ in the ACSF were raised (to $50 \mathrm{mM}$ ) for $5 \mathrm{~min}$. The slices were then washed twice with ACSF, whereupon they were incubated \pm CaEDTA $(0.1$ $\mathrm{mM})$ for 3 hours in carbogenated ACSF solution $(1 \mathrm{ml})$ at room temperature. Hence, the toxicity of $A \beta$ could only be attributed to the material that had precipitated (e.g. by 
endogenous $\mathrm{Zn}^{2+}$ release) and been trapped on the slices, and not been washed off. After 3 hours we added $0.1 \mathrm{ml} \mathrm{MTT}$ (stock solution $5 \mathrm{mg} / \mathrm{ml}$ ) to the chamber for $30 \mathrm{~min}$. The reduction of MTT was stopped by transferring the slices from ACSF to ice-cold $u_{p} \mathrm{H}_{2} \mathrm{O}$. We then transferred the slices to pure DMSO for $30 \mathrm{~min}$ to dissolve the formazan precipitate, followed by absorbance assay at 550 and $620 \mathrm{~nm}$. The results were normalized with the formula: $\left(\right.$ OD550 - OD620)/area of slice $\left(\mathrm{mm}^{2}\right)=100 \%$ in control rats.

\subsection{Measurement of total, vesicular and released $\mathrm{Zn}^{2+}$ and $\mathrm{A} \beta$ aggregation}

Freshly prepared hippocampal slices were immediately lyophilized and stored at $-80^{\circ} \mathrm{C}$ until analysis. At the start of the experiment the tissue was rehydrated in $u_{p} \mathrm{H}_{2} \mathrm{O}$, ultrasonicated and its protein content determined. Total zinc was measured by inductivelycoupled plasma mass spectrometry as previously described (Maynard et al., 2006).

Fluorescence was measured with a 96-well plate reader (NOVOstar OPTIMA, BMG Labtech, Budapest, Hungary) using the method described by Datki et al. (2007). After resting (30 min) in the carbogenated $\mathrm{Ca}^{2+}$-free ACSF solution at room temperature, the acute hippocampal slices (maximum 10) were washed for $30 \mathrm{~s}$ in $2 \mathrm{ml}$ preheated $\left(36{ }^{\circ} \mathrm{C}\right)$ carbogenated H-ACSF. The slices were then transferred from the mini-chamber to the plate wells and immobilized by a round non-fluorescent plastic grid. The H-ACSF was carefully removed and substituted with carbogen-saturated H-ACSF (40 $\mu$ per well) containing either $\mathrm{Zn}^{2+}$ fluorophore $(10 \mu \mathrm{M})$, or bis-ANS (indicator of peptide aggregation; $10 \mu \mathrm{M}$ ), or Thioflavine-T $(10 \mu \mathrm{M})$. For bis-ANS and Thioflavine- T peptide aggregation assays, the $\mathrm{H}$ ACSF solution was also supplemented with $\mathrm{A} \beta$ peptide $(50 \mu \mathrm{M})$. The plates and the H-ACSF solution were preheated to $36{ }^{\circ} \mathrm{C}$ before the slices were transferred. The temperature within the plate-reader was maintained $36^{\circ} \mathrm{C}$. The acute hippocampal slices were treated with additional $\mathrm{KCl}(50 \mathrm{mM})$ to induce depolarization or additional $\mathrm{NaCl}(50 \mathrm{mM})$ as an osmotic control. Measurement of fluorescence in the acute hippocampal preparations was started 1 min before the $\mathrm{KCl} / \mathrm{NaCl}$ treatment.

To prove that ZnAF2 is cell impermeable we treated SH-SY5Y human adrenergic neuroblastoma cells, as well as CHO cells with $10 \mu \mathrm{M}$ ZnAF2 in H-ACSF. After 10 minutes 
of incubation followed by washing with H-ACSF, there was no fluorescent signal above the background in the cells.

For studies of vesicular $\mathrm{Zn}^{2+}$ load, the slices were incubated with TFLZn $(0.3 \mathrm{mM})$ for 30 min in Ca-free ACSF, washed (3x) before measurement with the plate reader. Specificity was determined by abolishing fluorescence with the cell-impermeable $\mathrm{Zn}^{2+}$ chelator CaEDTA $(0.5 \mathrm{mM})$, which does not significantly affect extracellular $\mathrm{Ca}^{2+}$ concentration (Koh et al., 1996, Qian and Noebels, 2005) or cell-permeable TPEN for intracellular signals.

\subsection{Western blot analysis}

Hippocampal tissue $(10 \mu \mathrm{g})$ was blotted with anti-ZnT3 polyclonal antiserum as described by Smidt et al. (2009).

Normal and $\alpha \mathrm{SN}$ overexpressing differentiated neuroblastoma cells were extracted in PBS containing $1 \%$ Triton X-100 and 1\% protease inhibitor cocktail. The cell extracts were centrifuged at $16000 \times \mathrm{g}$ for $10 \mathrm{~min}$ and the supernatants were saved. $15 \mu \mathrm{g}$ of total protein was separated by sodium dodecyl sulfate-polyacrylamide gel electrophoresis (SDS-PAGE) under reducing conditions according to the method of Laemmli (1970). Proteins were blotted onto nitrocellulose membrane. The blot was incubated overnight in the presence of rabbit antialpha-synuclein polyclonal antibody diluted 1:500 in PBS. Then, the membrane was washed three times in PBS- $0.05 \%$ Tween and incubated for $2 \mathrm{~h}$ peroxidase-conjugated goat antirabbit IgG antibody diluted 1:10000 in PBS. Then the membrane was washed three times in PBS- $0.05 \%$ Tween. The immune complexes were detected with chemiluminescent substrate of peroxidase according to the supplier's instructions. Protein concentration was determined using a BCA assay kit. Images were densitometry analyzed using Scion Image software. Densitometric data were normalized for $\beta$-tubulin. 


\subsection{Analytical ultracentrifugation}

Analytical ultracentrifugation was performed by our Australian collaborators (by Dr. Ashley Bush and colleagues, Mental Health Research Institute, Parkville, Victoria, Australia) on a Beckman Optima XL-A. Sedimentation velocity runs were performed at $23{ }^{\circ} \mathrm{C}$ using a four-hole AN-60Ti rotor and double-sector charcoal/Epon-filled centerpieces. A $\beta(1-42)(15-$ $50 \mu \mathrm{M})$ and bis-ANS (30-100 $\mu \mathrm{M})$ samples $\left( \pm \mathrm{Zn}^{2+} 15-50 \mu \mathrm{M}\right)$ were centrifuged in Chelex 100 (Sigma) -treated PBS at 40,000 rpm. We allowed the temperature of the rotor to equilibrate for 30-60 min at 3,000 rpm, then the rotor speed was increased to 40,000 rpm and absorbance scans were taken every 2 minutes for a total of 100 scans (3.3 hours). For sedimentation velocity experiments without bis-ANS $A \beta(1-42)$ was monitored by Abs. $225 \mathrm{~nm}$. The wavelength used for bis-ANS sedimentation experiments was chosen so the total absorbance was 1.0 : $385 \mathrm{~nm}$ for bis-ANS $30 \mu \mathrm{M}, 420 \mathrm{~nm}$ for bis-ANS $100 \mu \mathrm{M}$. Scans were collected using absorbance optics in $0.003 \mathrm{~cm}$ radial steps. The data were fit using Sedfit software (Schuck, 2000). The frictional coefficient ratios (f/fo) for the bis-ANS and A $\beta$ experiments were 1.2 and 1.8 respectively. The 1.8 f/fo ratio for $A \beta$ is consistent with the shape of the molecules being elongated or fibril in structure. All s values are reported as $S_{20, w}$ values. The reproducibility of the curve fit is scrutinized by running Monte-Carlo ( $n=1000,0.95$ confidence interval) simulations, which allows us to assign a statistical confidence to the $\mathrm{c}(\mathrm{s})$ distribution that best describes the data.

\subsection{Multi-electrode array (MEA) electrophysiology}

One acute hippocampal slice was placed in a 3D-MEA chip with 60 tip-shaped and 60- $\mu$ m-high electrodes spaced by $100 \mu \mathrm{m}$ (Ayanda Biosystems, S.A., CH-1015 Lausanne, Switzerland). The surrounding solution was removed, and the slice was immobilized by a grid. The slice was continuously perfused with carbogenated ACSF $\left(1.5 \mathrm{ml} / \mathrm{min}\right.$ at $\left.34{ }^{\circ} \mathrm{C}\right)$ during the whole recording session. Data were recorded with a Multi-Channel System (MCS $\mathrm{GmbH}$, Reutlingen, Germany). The Schaffer-collateral was stimulated by injecting a biphasic current waveform $(100+100 \mu \mathrm{s})$ through one selected electrode at $0.033 \mathrm{~Hz}$. Care was taken 
to choose the stimulating electrode in the same region from one slice to the other. The peakto-peak amplitudes of field excitatory postsynaptic potentials (fEPSPs) at the proximal stratum radiatum of CA1 were analyzed. Following a $30 \mathrm{~min}$ incubation period, slices were continuously stimulated with medium-strength stimuli. When stable evoked fEPSPs were detected (for at least $20 \mathrm{~min}$ ), the stimulus threshold was determined, and a stimulus strengthevoked response curve (i.e. input-output, $\mathrm{I}-\mathrm{O}$ curve) was recorded by gradually increasing stimulus intensity until the maximal stimulus strength was reached. The stimulus intensity was continuously increased from 0 to $120 \mu \mathrm{A}$ with $10 \mu \mathrm{A}$ steps. Stronger stimulation led to large Faradic effects on the electrodes causing artifacts. 3 data sets were recorded for each stimulation intensity. The intensity of the test stimulus was set to be $30 \%$ of the threshold and maximum stimulus strength interval. After recording a 10 min stable control sequence, LTP was induced by applying theta-burst stimulation (TBS; trains of $15 \times 100 \mathrm{~Hz}$ bursts, 5 pulses per burst with a $200 \mathrm{~ms}$ interburst interval), at the maximum stimulation intensity, then fEPSPs were recorded for $60 \mathrm{~min}$. We analyzed the $20-80 \%$ slope of the initial portion of fEPSPs.

\subsection{Confocal microscopy}

Three-dimensional fluorescence confocal imaging was performed by using an Olympus Fluoview FV1000 confocal laser scanning microscope (Olympus Life Science Europa GmbH, Hamburg, Germany). The microscope configuration was: UPLFLN 40X oil immersion objective with the numerical aperture of 1.30 ; scanning dimensions- $512 \times 512$ pixels; sampling speed- $2 \mu \mathrm{s} /$ pixel; z-step size- $0.6 \mu \mathrm{m}$; number of z-sections- 36; confocal aperture- $358 \mu \mathrm{m}$; zoom- 2x; line averaging- 2x; scanning mode- sequential unidirectional; excitation- $405 \mathrm{~nm}$ (bis-ANS) and $543 \mathrm{~nm}(\mathrm{PI})$; laser transmissivity- $0.1 \%$ and $8 \%$ were used for bis-ANS and PI, respectively; main dichroic beam splitter- DM405/488/543; intermediate dichroic beam splitter- SDM 490; bis-ANS was detected between 470-520 nm using the spectral channel, PI was detected between 555-655 nm. Using Olympus Fluoview software (version 1.7.2.2) bis-ANS and PI images were pseudo colored green and red, respectively. 
"Three planes" visualization option of the Fluoview software was used to show $\mathrm{x}-\mathrm{z}$ and $\mathrm{y}-\mathrm{z}$ planes of 3-D image stacks.

\subsection{Treatments of differentiated $\alpha \mathrm{SN}$ normal and overexpressing cells}

The $\alpha \mathrm{SN}$ "normal expressing" (NE) and the $\alpha \mathrm{SN}$ "wild type overexpressing" (OE) SH-SY5Y cell lines were obtained from Alex Liu (Department of Neurology, University of Saarland, Homburg, Germany). The cells were grown till confluency in Dulbecco's modified Eagle's medium (MEM):F-12 (1:1), supplemented with FBS (10\%), L-Glutamine (4 mM), penicillin (200 units/ml), streptomycin $(200 \mu \mathrm{g} / \mathrm{ml})$, MEM non-essential amino acids RA $(10 \mu \mathrm{M})$ and TPA (16 nM) (Lambert et al., 1994, Flood et al., 2004, Presgraves et al., 2004) in 96-well plates in a humidified atmosphere $\left(37{ }^{\circ} \mathrm{C}, 5 \% \mathrm{CO}_{2}\right)$ for 8 days. The number of passages in case of both cell lines was 3. On the first day, the number of non-differentiated cells in the wells was $2.5 \times 10^{5}$ cells $/ \mathrm{ml}$. After 8-10 days of differentiation, the cells were attached to the plate as a monolayer, and cell counting indicated $3 \times 10^{5}$ cells $/ \mathrm{cm}^{2}$ (equals to $6.5 \times 10^{5}$ cells $/ \mathrm{ml}$ in suspension). Aggregation of $\mathrm{A} \beta(1-42)$ and NAC were performed in aqueous solution $(100 \mu \mathrm{M})$ by gentle shaking at room temperature for $1 \mathrm{~h}$ or 8 days. In order to prevent infection, the solutions were ultrasonicated daily. The aggregation states of the peptides were: $1 \mathrm{~h}$ pre-aggregated $\mathrm{A} \beta(1-42)$ (protofibrils), 8-day pre-aggregated $\mathrm{A} \beta(1-42)$ (fibrils) (Fulop et al., 2004), $1 \mathrm{~h}$ pre-aggregated NAC (protofibrils) and 8-day pre-aggregated NAC (fibrils; TEM pictures not shown). The original supernatant solution was removed from the cells with a pipette, and a new medium (100 $\mu \mathrm{l} /$ well, containing $2 \%$ FBS and aggregated $\mathrm{A} \beta(1-42)$ or NAC in $10 \mu \mathrm{M}$ concentration) was quickly added to the wells and was kept at $37^{\circ} \mathrm{C}$ for $24 \mathrm{~h}$.

\subsection{MTT bioassay for $\alpha \mathrm{SN}$ normal and overexpressing cell culture}

3-(4,5-Dimethylthiazol-2-yl)-2,5-diphenyl-tetrazolium bromide (MTT), a widely used assay was performed to compare the viability of cells (Liu et al., 1997). Differentiated neuroblastoma cells (Datki et al., 2003) were incubated in a 96-well plate for $24 \mathrm{~h}$ with the 
following peptides: (a) $10 \mu \mathrm{M}$ of $\mathrm{A} \beta(1-42)$ pre-aggregated for $1 \mathrm{~h}$ or 8 days; (b) $10 \mu \mathrm{M}$ NAC pre-aggregated for $1 \mathrm{~h}$ or 8 days. In a second set of experiment, cells were treated with the following classical apoptotic factors: $\mathrm{H}_{2} \mathrm{O}_{2}(40 \mu \mathrm{M})$, amphotericin $\mathrm{B}(3 \mu \mathrm{M})$ and ruthenium red $(200 \mu \mathrm{M})$. MTT solution was added to each well $(0.4 \mathrm{mg} / \mathrm{ml})$, containing $100 \mu \mathrm{l}$ cell culture medium, and then the mixture was incubated for $3 \mathrm{~h}$. The MTT solution was carefully decanted and formazan was extracted from the cells using $100 \mu \mathrm{l} /$ well of a DMSO/EtOH (4:1, $\mathrm{v} / \mathrm{v}$ ). The color intensity of formazan was measured by a 96-well plate reader (BMG Labtech, Budapest, Hungary) at $550 \mathrm{~nm}$. All MTT assays were triplicated, hence, one measurement contained seven parallels $(n=21)$.

\subsection{Statistical analysis}

Data are presented as mean \pm S.E.M. Unpaired Student's $t$-test (for Western blot analysis) and ANOVA with post hoc Bonferroni or Tukey was used for statistical evaluation, both performed by GraphPad Prism 5.0 software. A $p \leq 0.05$ value was considered statistically significant, unless otherwise stated (e.g. $p \leq 0.01 ; p \leq 0.001$ ). 


\section{Results}

\subsection{Experiments on the role of $\mathrm{Zn}^{2+}$ dishomeostasis in $\mathrm{A} \beta$ aggregation}

\subsubsection{Activated hippocampal slices from aged rats release more zinc}

Slices from young (10-weeks-old) rats were found to release $\mathrm{Zn}^{2+}$ upon stimulation with $50 \mathrm{mM} \mathrm{K}^{+}$, in a $\mathrm{Ca}^{2+}$-dependent manner (Fig. 4a), as reported previously (Datki et al., 2007). CaEDTA, a cell-impermeable $\mathrm{Zn}^{2+}$ chelator that does not affect extracellular $\mathrm{Ca}^{2+}$ concentrations (Koh et al., 1996) rapidly reversed the signal, indicating that the indicator was detecting $\mathrm{Zn}^{2+}$ released from the slices (Fig. 4a). Results were confirmed using two different cell impermeable $\mathrm{Zn}^{2+}$ indicators, RhodZin3 and ZnAF2. Using this system, we found that the maximal extracellular $\mathrm{Zn}^{2+}$ concentrations produced by $\mathrm{K}^{+}$stimulation were significantly higher $(+50-70 \%)$ in slices from older rats (65-weeks-old) (Fig. 4b). While there was no difference between young males and females in the amounts of $\mathrm{Zn}^{2+}$ released, older male hippocampi released $\approx 50 \%$ more $\mathrm{Zn}^{2+}$ than young males, and older females released $\approx 70 \%$ more $\mathrm{Zn}^{2+}$ than young females and significantly more $(\approx 20 \%)$ than old males (Fig. $4 \mathrm{~b}$ ).

The phenomenon that the slices are sensitive to mechanical trauma in different extent was excluded by measuring LDH release into the media after preparation, which demonstrated no difference between slices taken from young and old rats $(2.819 \pm 0.029$ $\mathrm{U} / \mathrm{ml}, \mathrm{n}=12$ vs. $2.849 \pm 0.130 \mathrm{U} / \mathrm{ml}, \mathrm{n}=12, \mathrm{p}=0.46$ ). We measured the levels of total zinc in young and old hippocampi to determine whether differences in total zinc could be the reason for increased $\mathrm{Zn}^{2+}$ release, and found the levels to be unchanged with age even in a sample of "very old" 17 month old rats (Fig. 4c). 
a

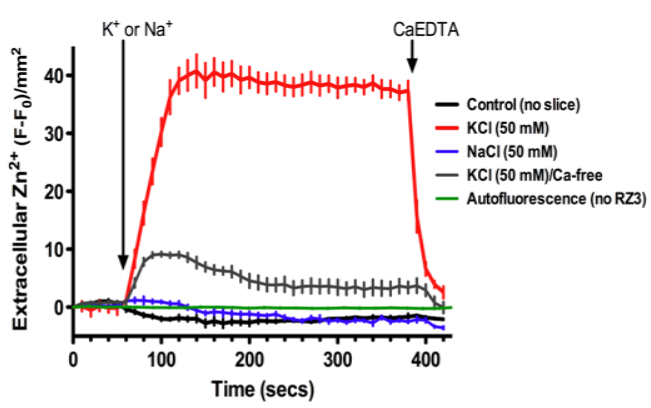

b

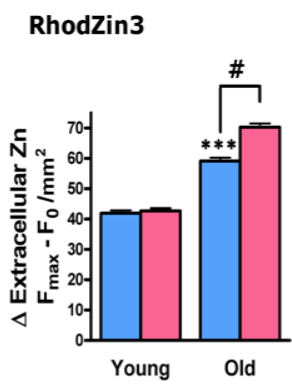

ZnAF2

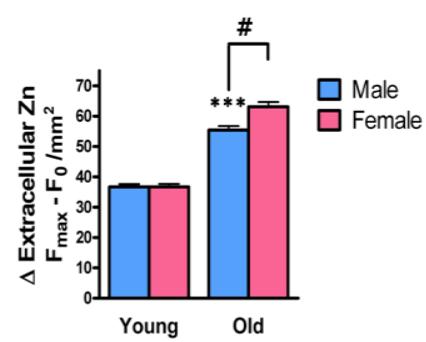

C

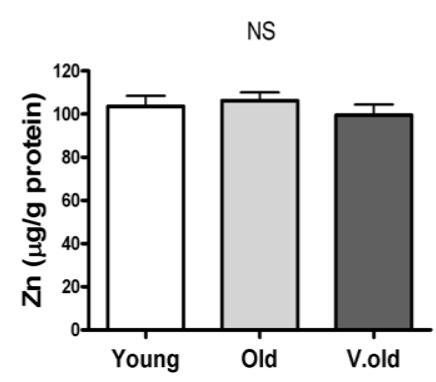

d

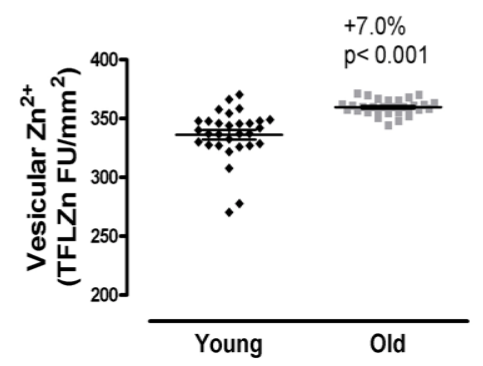

e

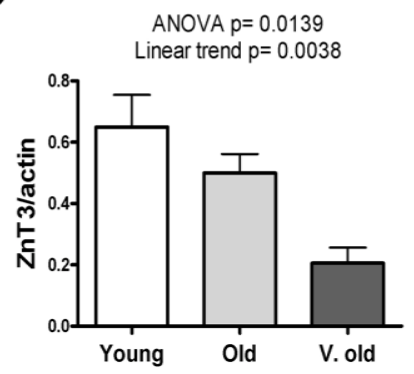

Figure 4. Age and gender affect $\mathrm{Zn}^{2+}$ release from rat acute hippocampal slices. (a) Release of $\mathrm{Zn}^{2+}$ from slices taken from 10-weeks-old male rats, depolarized with high $\mathrm{K}^{+}$in $\mathrm{H}$-ACSF supplemented with the cell-impermeable $\mathrm{Zn}^{2+}$-indicator RhodZin $3(10 \mu M)$. Data are means $\pm S E M, n=5$ experiments. (b) Increased depolarization-induced $\mathrm{Zn}^{2+}$ release from older and female slices. Data are mean $\triangle F \max \left( \pm S E M, n=60\right.$ ) of two different impermeant $\mathrm{Zn}^{2+}$ fluorophores (RhodZin3 and ZnAF2, indicated) taken within 120 secs of depolarization with high $K^{+}$. ${ }^{* * *} p<0.001$, compared to the mean $\triangle Z n$ of young male and female slices; \# $p<0.001$, between old male and female slices, Tukey's multiple comparison test. (c) Mean total Zn levels ( \pm SEM, $n=10$ for young and old, $n=5$ for 17 month " $V$. old") in male hippocampal slices measured by inductively coupled plasma mass spectrometry are indicated. (d) Mean intravesicular $\mathrm{Zn}^{2+}$ levels in male hippocampal slices detected by TFLZn fluorescence, normalized to slice surface area ( \pm SEM, $n=30$ for each group), are indicated. (e) ZnT3 levels in male hippocampal slices (means $\pm S E M, n=10$ for young and old, $n=5$ for V. old).

Since the releasable pool of $\mathrm{Zn}^{2+}$ is in synaptic vesicles, we also assayed for this fraction using TFLZn, which selectively detects vesicular $\mathrm{Zn}^{2+}$, in the young and old rat hippocampi, as previously described (Budde et al., 1997). There was indeed a small (7.0\%) but significant increase in vesicular $\mathrm{Zn}^{2+}$ in slices from old rats compared to young ones (Fig. $4 d)$. 
One explanation of this increase in vesicular $\mathrm{Zn}^{2+}$ could be the increased expression of $\mathrm{ZnT3}$, the transporter of synaptic vesicular $\mathrm{Zn}^{2+}$. Surprisingly, western blot analysis of the slices indicated that ZnT3 levels actually decrease significantly with age, with additional samples from 17-month old rats expressing even lower levels (Fig. 4e). Taken together, these data indicate that, with age, the hippocampal vesicular $\mathrm{Zn}^{2+}$ pool enlarges (Fig. 4d), despite the lower ZnT3 expression (Fig. 4e). Therefore, activity-dependent $\mathrm{Zn}^{2+}$-release must be less frequent with aging. If $\mathrm{Zn}^{2+}$ release is decreased in older tissue, $\mathrm{Zn}^{2+}$-uptake would need to be inhibited to maintain the balance, because there are no changes in total zinc levels (Fig. 4c). The increased release of $\mathrm{Zn}^{2+}$ from female hippocampus could be explained by increased ZnT3 expression (Friedlich et al., 2004), however, the $7.0 \%$ increase in vesicular $\mathrm{Zn}^{2+}$ in slices from old compared to young rats (Fig. 4d) seems too small to explain the $\approx 50 \%$ increase in extracellular $\mathrm{Zn}^{2+}$ released from old rat slices upon $\mathrm{K}^{+}$stimulation (Fig. 4b). Therefore, we explored next whether the changes we observed with age and gender could also be explained by impaired reuptake of extracellular $\mathrm{Zn}^{2+}$.

\subsubsection{Impaired reuptake of extracellular zinc by older hippocampal slices}

Constant high levels of extracellular $\mathrm{Zn}^{2+}$ are potentially neurotoxic (Choi et al., 1988), therefore synaptic $\mathrm{Zn}^{2+}$ must rise only briefly during neurotransmission. In the hippocampal tissue there is most likely to be a robust and possibly energy dependent $\mathrm{Zn}^{2+}$ reuptake process. Double-labeling experiments that can differ extracellular from intracellular $\mathrm{Zn}^{2+}$, revealed an increased level of intracellular $\mathrm{Zn}^{2+}$ within seconds of $\mathrm{Zn}^{2+}$ being released into the media by stimulation of the slices with high $\mathrm{K}^{+}$(Fig. 5a). To prove that there is a reuptake of $\mathrm{Zn}^{2+}$ after the incited release, we stimulated the slice with high $\mathrm{K}^{+}$in the presence of CaEDTA (rather than adding it after stimulation), and thus any $\mathrm{Zn}^{2+}$ released extracellular space is captured by the impermeable chelator. Indeed, this reduced the rise in intracellular $\mathrm{Zn}^{2+}$ (Fig. 5b). CaEDTA alone did not decrease intracellular $\mathrm{Zn}^{2+}$ (Fig. 5a). Then, we repeated the experiment in the presence of $\mathrm{Ca}^{2+}$-free $\mathrm{H}-\mathrm{ACSF}$ (artificial CSF supplemented with HEPES), which suppresses vesicular release of $\mathrm{Zn}^{2+}$ (Fig. 4a). This also suppressed the rise in intracellular $\mathrm{Zn}^{2+}$ (Fig. 5b), consistent with the elevated $\mathrm{Zn}^{2+}$ originating from the release of synaptic vesicles. The rate of $\mathrm{Zn}^{2+}$ reuptake released from young hippocampal slices is 
significantly higher than the reuptake of old rat slices, for both males and females (Fig. 5c). This is consistent with the increase in extracellular $\mathrm{Zn}^{2+}$, we observed in stimulated old rat slices (Fig. 4b), caused by inhibited reuptake.

a

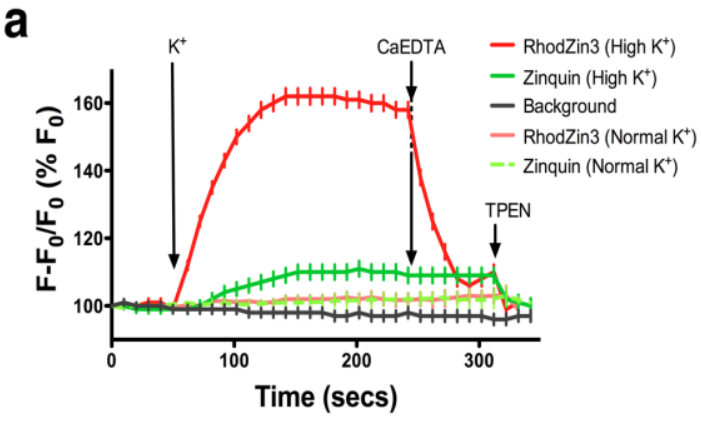

C

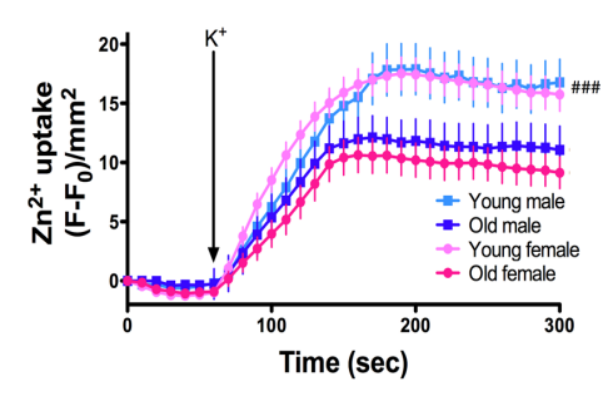

e

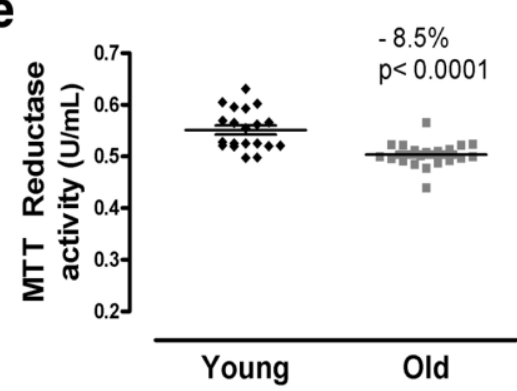

b
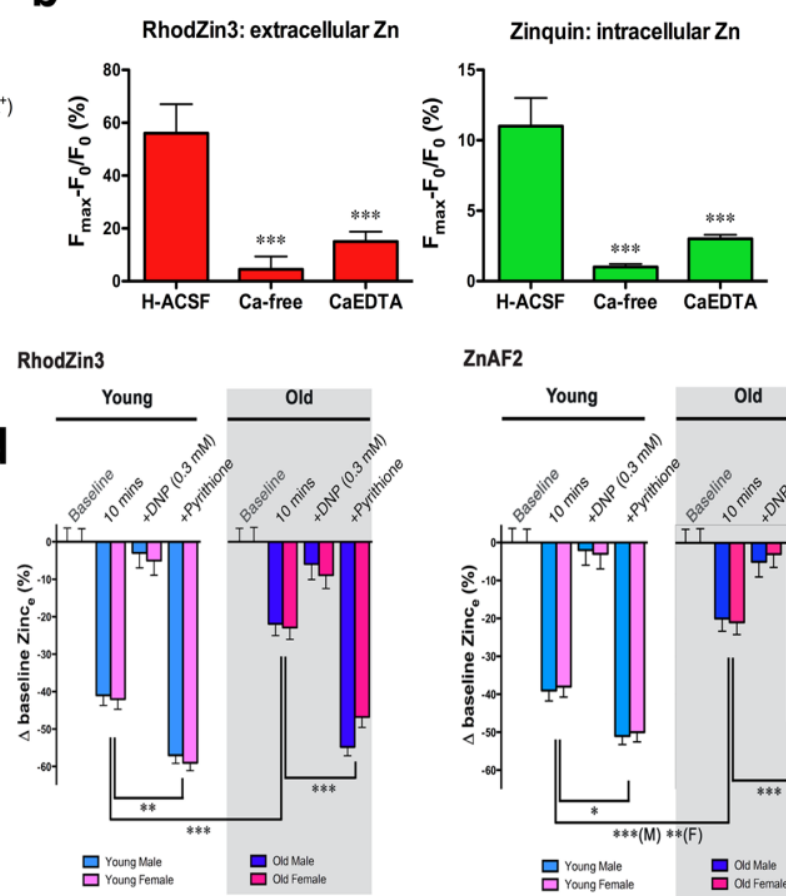

ZnAF2

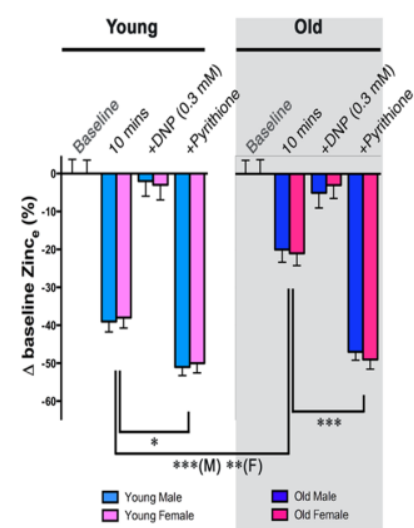

f

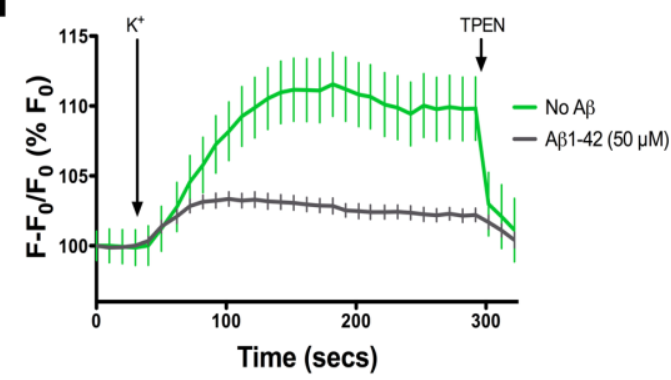

Figure 5. Effects of age, gender and mitochondrial function on $\mathrm{Zn}^{2+}$ uptake in rat acute hippocampal slices. (a) Slices from young male rats were preloaded with Zinquin, which detects free intracellular $\mathrm{Zn}^{2+}$, before being introduced into HACSF supplemented with RhodZin-3, which detects extracellular $\mathrm{Zn}^{2+}$, whereupon fluorescence of the two fluorophores is recorded simultaneously. (b) Slices were prepared as in (a), but were stimulated with high $\mathrm{K}^{+}$either in the presence of Ca-free $\mathrm{H}$ -

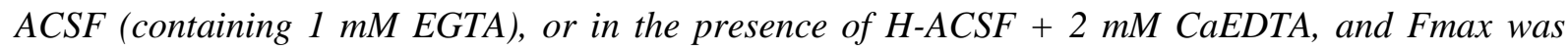
determined. (c) The rise in the intracellular free $\mathrm{Zn}^{2+}$ detected by Zinquin in slices from young compared to old female and male rats following $\mathrm{K}^{+}$stimulation. Data are means $( \pm S E M$, males $n=$ 10 , females $n=20$ slices). Slopes from $60-160$ secs were significantly greater for young compared to 
old gender matched rats $(p<0.001)$. ANOVA with post-hoc Tukey's was performed on values 200 secs onwards: \#\#\# young and old groups were significantly different from each other within their respective genders $(p<0.001)$. (d) Residual extracellular $\mathrm{Zn}^{2+}\left(\right.$ Zinc $\left._{e}\right)$ levels of hippocampal slices after bathing and resting in $\mathrm{H}$-ACSF for 30 secs (baseline) and 10 mins after introducing $2 \mu \mathrm{M} \mathrm{ZnSO}_{4}$. (e) MTT assay results from freshly prepared hippocampal slices. (f) Uptake of $\mathrm{Zn}^{2+}$ into hippocampal slices from young male rat slices treated with $A \beta(1-42)(50 \mu M)$, monitored by Zinquin fluorescence. Values were calculated following background fluorescence subtraction. Data are means ( \pm SEM, $\boldsymbol{a}, \boldsymbol{b}, \boldsymbol{c}, \boldsymbol{f} n=5$ chambers, each containing 10 slices). For c, ANOVA with Bonferroni multiple comparison correction. \# $p<0.01, * * * p<0.001$. For $\boldsymbol{e}$, unpaired t-test values are shown.

To confirm that the $\mathrm{Zn}^{2+}$ uptake in older slices is disrupted, we studied uptake when a fixed amount of $\mathrm{Zn}^{2+}$ was added to the incubation media. Using extracellular $\mathrm{Zn}^{2+}$ indicators RhodZin3 and ZnAF2, we observed that $\approx 40 \%$ of the added $\mathrm{Zn}^{2+}(2 \mu \mathrm{M}$, a subtoxic concentration) was consumed within 10 minutes from the overlying media of young slices, but that significantly less $\mathrm{Zn}^{2+}$ was cleared from the media of old slices (Fig. 5d). In addition, the $\mathrm{Zn}^{2+}$ ionophore pyrithione (Colvin et al., 2008) caused the clearance of $\mathrm{Zn}^{2+}$ from both young and old slices within 10 minutes (Fig. 5d), confirming that we observed uptake. Treatment of the slices with a sub-toxic concentration of the mitochondrial uncoupler agent DNP (Mattson et al., 1993) markedly ruined the uptake of $\mathrm{Zn}^{2+}$ (Fig. 5d), indicating that energy impairment could explain the inadequate $\mathrm{Zn}^{2+}$ reuptake observed in old slices. There was no difference in uptake between genders under these conditions (Fig. 5d). Therefore, the increased release of $\mathrm{Zn}^{2+}$ from $\mathrm{K}^{+}$-treated older female slices (Fig. 4b) probably reflects a higher maximal capacity for $\mathrm{Zn}^{2+}$-release.

To check if an age-dependent decrease in mitochondrial activity was the cause of the impaired $\mathrm{Zn}^{2+}$ reuptake in older slices, we measured the MTT reductase activity (indicator of mitochondrial activity) of the slices after the preparation process, and found that the older rat slices had markedly less activity (-8.5\%) than slices from the young animals (Fig. 5e). Consequently, the inhibited reuptake of released $\mathrm{Zn}^{2+}$, which is caused by age dependent mitochondrial failure, is responsible for the increase in extracellular $\mathrm{Zn}^{2+}$ in case of activated older hippocampal slices.

The chelation of extracellular $\mathrm{Zn}^{2+}$ by $\mathrm{A} \beta$ aggregates which then prevent $\mathrm{Zn}^{2+}$ to reach post-synaptic targets might have a role in AD cognitive loss (Adlard et al., 2010). To test this, 
we studied $\mathrm{Zn}^{2+}$ uptake into slices with Zinquin following high $\mathrm{K}^{+}$stimulation (Fig. 5f), which releases extracellular $\mathrm{Zn}^{2+}$ (Fig. 4a).The results showed, that the slices treated with $\mathrm{A} \beta(1-42)(50 \mu \mathrm{M})$ had significantly less $\mathrm{Zn}^{2+}$ reuptake than untreated slices.

\subsection{3. $\mathrm{Zn}^{2+}$ from activated hippocampal slices induces $A \beta(1-42)$ oligomerization}

Next we investigated whether $\mathrm{Zn}^{2+}$ release from the hippocampal slices could induce the aggregation of synthetic $A \beta(1-42)$ added to the media. We monitored aggregation with bis-ANS, a fluorescent indicator of prefibrillar, low-order oligomers (LeVine, 2002, Kayed and Glabe, 2006) which are markedly neurotoxic (Ferrao-Gonzales et al., 2005), as well as thioflavine-T, a fluorophore for fibrillar species (LeVine, 2002). As a control, we used a synthetic mutant of $A \beta(1-42)$ with histidine-to-alanine substitutions at residues 13 and 14 $\left(\mathrm{A} \beta_{\triangle 2 \mathrm{His}}\right.$ ), which reduce its ability to bind $\mathrm{Zn}^{2+}$ (Liu et al., 1999). In vitro, bis-ANS showed marked aggregation of $\mathrm{A} \beta(1-42)$ induced by $\mathrm{Zn}^{2+}(50 \mu \mathrm{M})$ within seconds, and was rapidly reversed by addition of the $\mathrm{Zn}^{2+}$ chelator CaEDTA (0.5 mM, Fig. 6a). In the absence of $\mathrm{Zn}^{2+}$, $\mathrm{A} \beta(1-42)$ aggregation was relatively slow and incomplete (Fig. 6a), and was not changed by addition of $50 \mathrm{mM} \mathrm{K}^{+}$(used in subsequent experiments to stimulate slices). A $\beta_{\Delta 2 \mathrm{His}}(50 \mu \mathrm{M})$ self-aggregation was much slower as detected by bis-ANS and it was only slightly increased

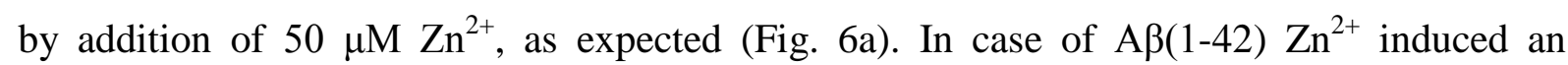
elevated bis-ANS fluorescence in a concentration-dependent manner (Fig. 6b). Since thioflavine-T fluorescence did not increase for $A \beta(1-42)$ incubated for 1000 seconds under

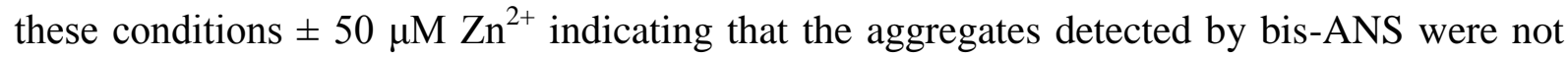
fibrils, but prefibrillar, low-order oligomers.
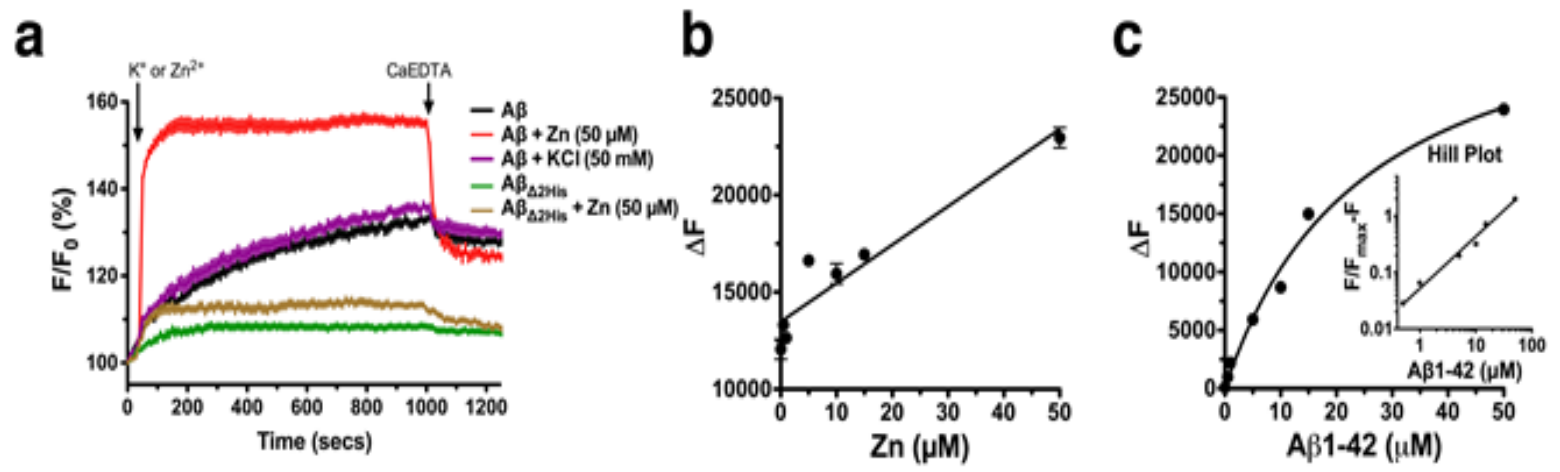


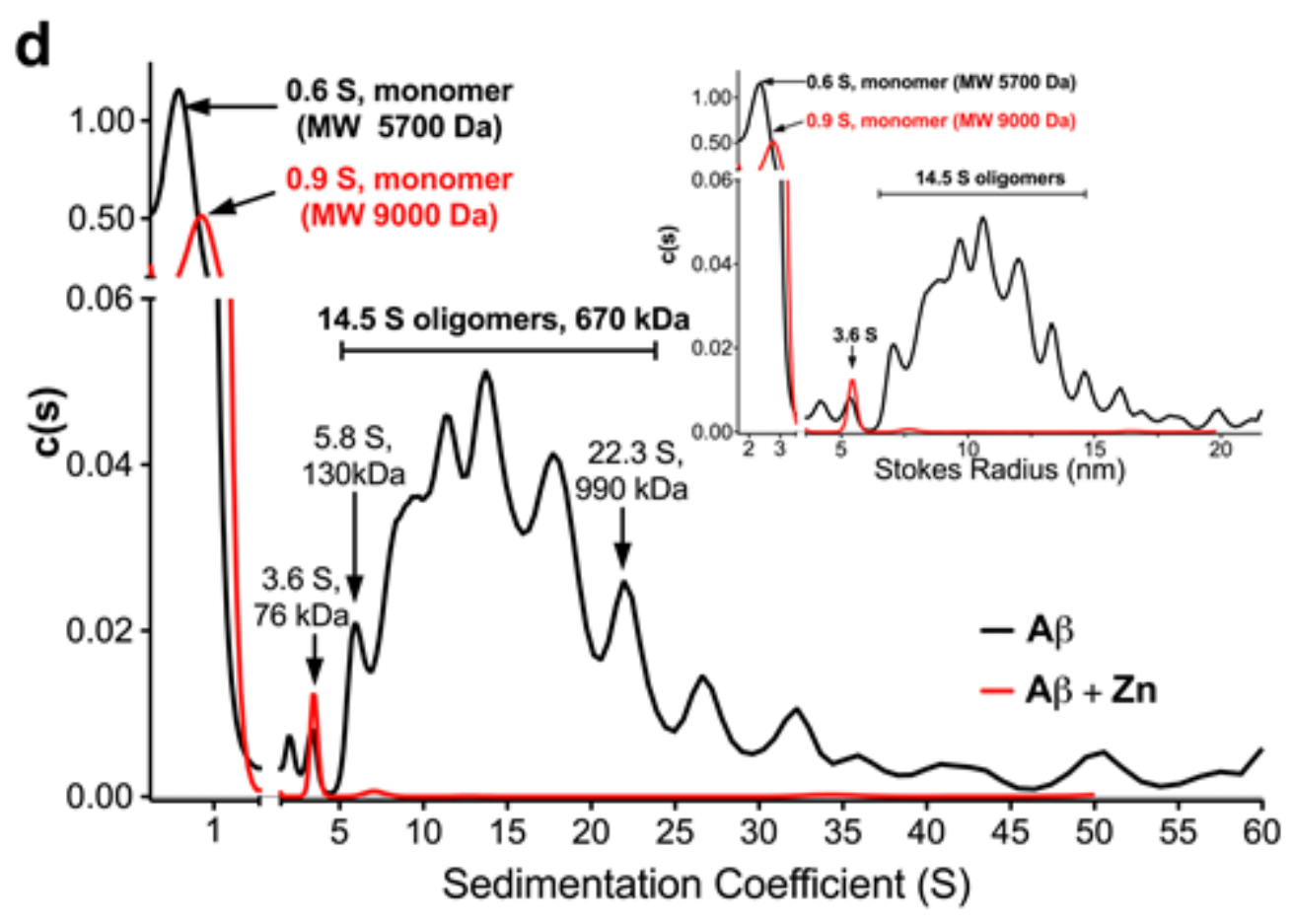

e

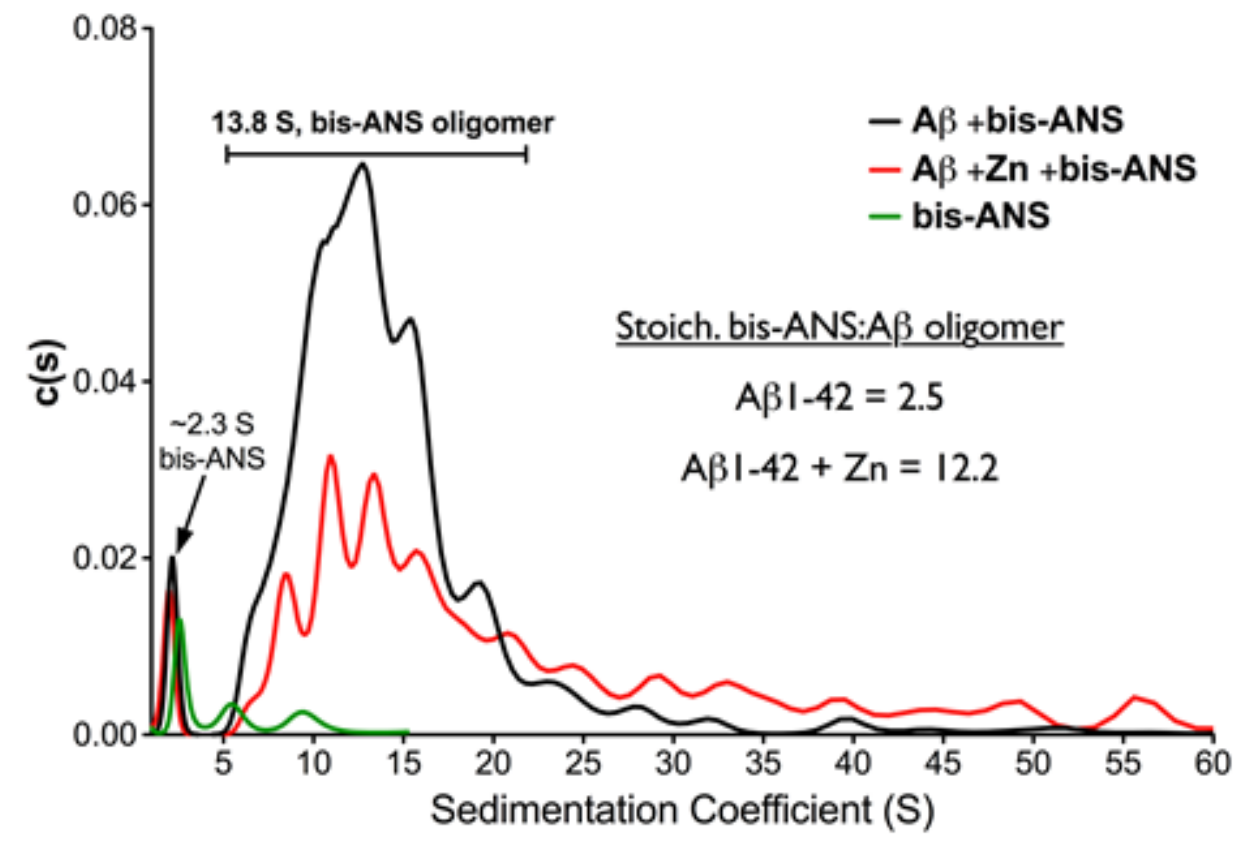

Figure 6. In vitro bis-ANS assay for Aß aggregation. (a) $A \beta(1-42)$, or the non- $\mathrm{Zn}^{2+}$ binding mutant $A \beta_{\triangle 2 H i s}$, was incubated in $\mathrm{H}$-ACSF containing bis-ANS $(10 \mu \mathrm{M}) \pm \mathrm{Zn}^{2+}$ or $\mathrm{K}^{+}$, added after 50 secs to represent conditions in Figure 7a. Data are mean $\triangle F \pm S E M, n$ (well) $=30$. (b) bis-ANS fluorescence (subtracting background) of a solution of $A \beta(1-42)(50 \mu M)$ incubated (5 minutes, RT) in H-ACSF with bis-ANS $(10 \mu M)$ and various $\mathrm{Zn}^{2+}$ concentrations (indicated). (c) bis-ANS fluorescence (subtracting 
background) of a solution of AB(1-42) (concentrations indicated) incubated (5 minutes, RT) in $\mathrm{H}$ ACSF with bis-ANS $(10 \mu \mathrm{M})$ and $\mathrm{Zn}^{2+}(50 \mu \mathrm{M})$. The slope of the Hill plot is 1.0 indicating noncooperativity. (d, e) Analytical Ultracentrifugation of $A \beta(1-42)$. (d) $A \beta(1-42)$ in the absence of bisANS demonstrated a $40: 60$ distribution of monomer : oligomer respectively (black line). (e) Bis-ANS detects oligomers of $A \beta$ and not monomers as demonstrated by the sedimentation of bis-ANS :A $\beta$ complexes detected by monitoring the absorbance of bis-ANS.

As far as we know, this is the first description of bis-ANS-reactive prefibrillar A $\beta$ which aggregates rapidly when induced by $\mathrm{Zn}^{2+}$. We determined the increase in bis-ANS fluorescence induced by a 5 minute incubation with $\mathrm{Zn}^{2+}$ over a range of $\mathrm{A} \beta(1-42)$ concentrations. Even a low $(0.5 \mu \mathrm{M})$ concentration had a significantly higher signal than background, and there was a non-cooperative (slope of the Hill plot is 1.0) log-linear increase in fluorescence with peptide concentration (Fig. 6c). Therefore, structural changes of $\mathrm{A} \beta(1-42)$ could be expected to occur even at low peptide concentrations..

To characterize soluble $A \beta(1-42)$ oligomers detected by bis-ANS, analytical ultracentrifugation was performed. By monitoring A $\beta$ directly without bis- ANS (by $225 \mathrm{~nm}$ absorbance), sedimentation velocity analysis showed a distinct peak at $0.6 \mathrm{~S}$ that corresponds to monomeric $\mathrm{A} \beta$ (apparent $\mathrm{MW} \approx 5700 \mathrm{Da}$, Fig 6d) and a multimodal distribution of oligomeric $A \beta$ species that ranged between 5-30 S (14.5 S average, MW $670 \mathrm{kDa}$, Fig 6d). The ratio was $\approx 40 \%$ monomers and $\approx 60 \%$ oligomers. The multimodal character of the oligomers and wide range of peak distribution indicate that the oligomeric species are in rapid exchange (Schuck, 2000). The addition of equimolar $\mathrm{Zn}^{2+}$ precipitated $57.6 \%$ of the soluble $\mathrm{A} \beta(1-42)(50 \mu \mathrm{M})$ to the bottom of the cell, where it could not be analyzed by analytical ultracentrifugation under these conditions, leaving 34\% remaining monomeric (0.9 S) and $8.4 \%$ remaining as soluble oligomer (mainly $3.7 \mathrm{~S}$, with <1\% oligomers 5-40 S). Similar results were achieved with $15 \mu \mathrm{M} A \beta(1-42)$. Taken together this data indicate that the addition of $\mathrm{Zn}^{2+}$ selectively precipitate soluble oligomers, as previously reported (Bush et al., 1994a).

While bis-ANS did not bind monomeric $A \beta$, the $\mathrm{c}(\mathrm{s})$ distribution of soluble $\mathrm{A} \beta$ oligomers detected by bis-ANS (Fig. 6e) was similar to that without bis-ANS (Fig. 6d), ranging between 5-25 S (13.8 S average). Bis-ANS detected abundant soluble oligomers in the $\mathrm{A} \beta: \mathrm{Zn}^{2+}$ mixture in the 5-25 $\mathrm{S}$ range, similar to the oligomer distribution in the absence of 
$\mathrm{Zn}^{2+}$, despite there was $<1 \%$ of soluble $\mathrm{A} \beta \geq 5 \mathrm{~S}$ detectable by UV absorbance, with continuous broad distribution of species from 25-60 S. The continuous distribution from $25-$ $60 \mathrm{~S}$ indicates that $\mathrm{Zn}^{2+}$ increases the rate of exchange between interacting $\mathrm{A} \beta(1-42)$ oligomeric species. The detection of soluble $A \beta$ oligomers in the presence of $\mathrm{Zn}^{2+}$ by bisANS that were near-invisible by $225 \mathrm{~nm}$ absorbance indicates that $\mathrm{Zn}^{2+}$-induced oligomers bind bis-ANS with a greater stoichiometric ratio. Based on the molar extinction coefficients of $\mathrm{A} \beta(1-42)$ and bis-ANS, we calculated that without $\mathrm{Zn}^{2+}$ there are $\approx 2.5$ bis-ANS molecules per $\mathrm{A} \beta$ (within soluble oligomers of 5-60 S), whereas with $\mathrm{Zn}^{2+}$ this increases to $\approx 12.2$ bisANS molecules per $\mathrm{A} \beta: \mathrm{Zn}^{2+}$ molecule. These data indicate that bis-ANS detects soluble $\mathrm{A} \beta(1-42)$ oligomers and $\mathrm{Zn}^{2+}$ changes the dynamics of $\mathrm{A} \beta$ oligomerization. Importantly, Stokes' radius analysis indicates that these oligomers are less than $20 \mathrm{~nm}$ in diameter, thus they can penetrate into the synaptic cleft.

We next tested whether bis-ANS-positive A $\beta$ oligomers could be formed by the endogenous $\mathrm{Zn}^{2+}$ released from rat hippocampal slices. Freshly dissolved synthetic A $\beta(1-42)$ was added to the slices in carbogenated H-ACSF containing bis-ANS and then they were stimulated with $50 \mathrm{mM} \mathrm{K}{ }^{+}$, as in Figs. $4 \mathrm{a}$ and $5 \mathrm{a}$, to induce $\mathrm{Zn}^{2+}$ release. Bis-ANS showed rapid $A \beta(1-42)$ aggregation after the stimulation with $50 \mathrm{mM} \mathrm{K}^{+}$(Fig. 7a), and the possibility that $\mathrm{K}^{+}$addition was responsible for this phenomenon was excluded (Fig. 6a). The rapid aggregation of $A \beta(1-42)$ was inhibited when $\mathrm{Ca}^{2+}$ was removed from the high $\mathrm{K}^{+}$buffer (Fig. 7a), which means that the aggregating factor was released upon synaptic activation. Aggregation was reversible by addition of CaEDTA and no aggregation was observed upon high $\mathrm{K}^{+}$depolarization of the slices which were incubated with $\mathrm{A} \beta_{\Delta 2 \mathrm{His}}$ (Fig. 7a), therefore it proves that the aggregating factor is $\mathrm{Zn}^{2+}$ which is released by the hippocampus upon activation. 


\section{a}

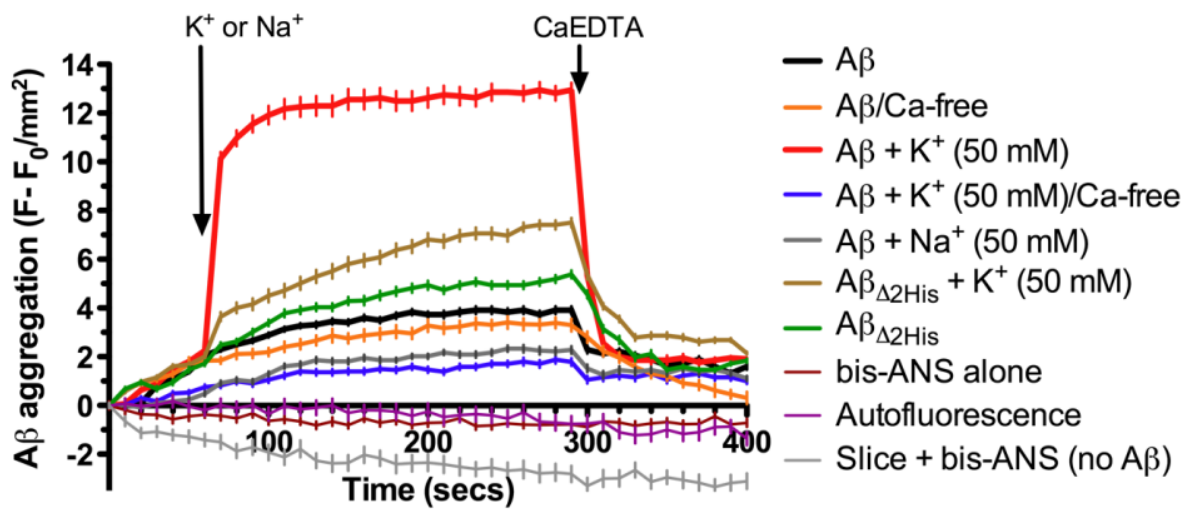

b

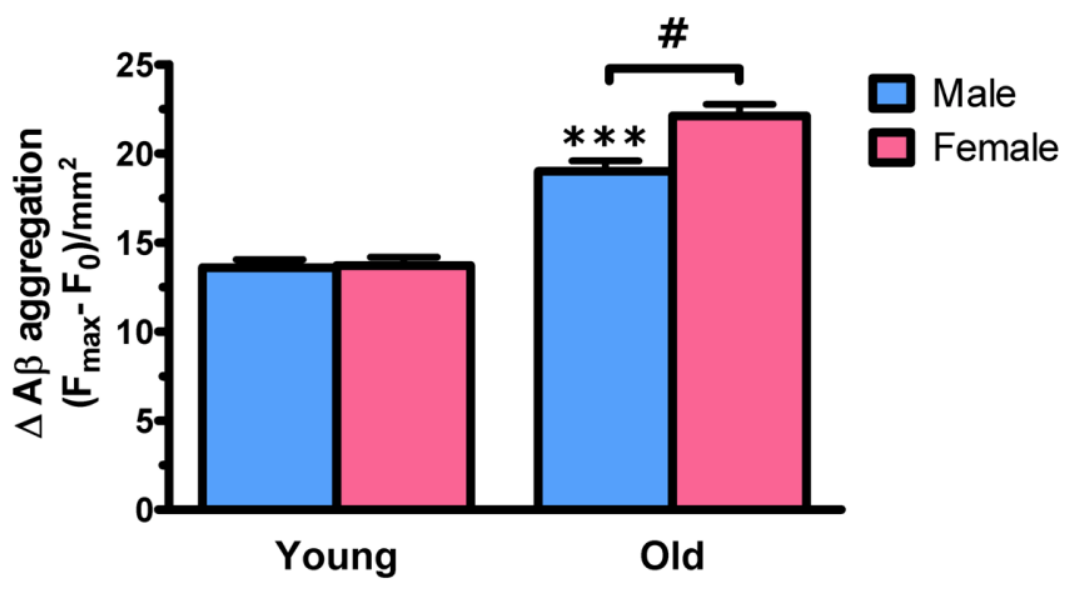

Figure 7. Aß aggregation on hippocampal slices assayed by bis-ANS fluorescence. (a) Slices from young male rats were incubated with $A \beta(1-42)(50 \mu M)$ or mutant $A \beta(1-42)$ lacking $\mathrm{Zn}^{2+}$-coordinating histidines $\left(A \beta_{\Delta 2 H i s}\right)$. (b) Age and gender modulate $A \beta$ aggregation monitored by bis-ANS fluorescence. The data are mean $\Delta F_{\max }$ of bis-ANS fluorescence induced by high $K^{+}$treatment of hippocampal slices. $* * * p<0.001, \# p<0.002$, ANOVA with post hoc $t$-tests, $n=30$ slices per condition.

Hippocampal slices from older (65-weeks-old) rats activated by high $\mathrm{K}^{+}$, induced significantly more aggregation of $A \beta(1-42)$ than slices from younger (10-weeks-old) rats (Fig. $7 b$ ), and slices from older female rats induced significantly more aggregation than slices from older male rats (Fig. 7b). The greater $A \beta$ aggregation from older and female slices are consistent with being mediated by the increased extracellular $\mathrm{Zn}^{2+}$ levels recorded under these conditions (Fig. 4b), and consistent with the pathology of AD. 


\subsubsection{Endogenous $\mathrm{Zn}^{2+}$ mediates $A \beta(1-42)$ synaptotoxicity}

In the next step we investigated the consequences of $\mathrm{Zn}^{2+}$-induced $\mathrm{A} \beta$ aggregation on the function and viability of the hippocampus. Using MEA technique on slices from 10-weeks-old male rats, we studied LTP induced by TBS. Acute slices were incubated in ExViS chambers with $\mathrm{A} \beta(1-42)\left(15 \mu \mathrm{M}\right.$ in ACSF) for $10 \mathrm{~min}$, followed by high $\mathrm{K}^{+}(50 \mathrm{mM}$ in ACSF) for $5 \mathrm{~min}$ to induce $\mathrm{Zn}^{2+}$ release and $\mathrm{A} \beta$ aggregation. Then, we washed the slices twice with ACSF to remove unbound $A \beta$, and incubated \pm CaEDTA $(0.1 \mathrm{mM}$, as a control to reverse the $\mathrm{Zn}^{2+}$-induced $\mathrm{A} \beta$ aggregates) for a further $1 \mathrm{~h}$ in the incubation chamber, after that the slices were transferred to the MEA chip perfused by carbogenated ACSF and rested for an additional $30 \mathrm{~min}$. These measures were to ensure that LTP was not induced by $\mathrm{K}^{+}$-induced depolarization, and that any change in LTP was due only to A $\beta$ remaining on the tissue and not due to $A \beta$ remaining soluble in the perfusate. Input/output curves were obtained for every slice, but did not show any significant difference among the treatment groups (data not shown), indicating normal basal synaptic function. TBS and subsequent LTP recordings were then performed over $30 \mathrm{~min}$. Slices were stimulated in the Schaffer-collateral, and recordings were made in the proximal stratum radiatum of CA1. Normal LTP could be induced in the $\mathrm{K}^{+}$- treated slices (Fig. 8a), demonstrating that the underlying pathways of LTP remained intact.

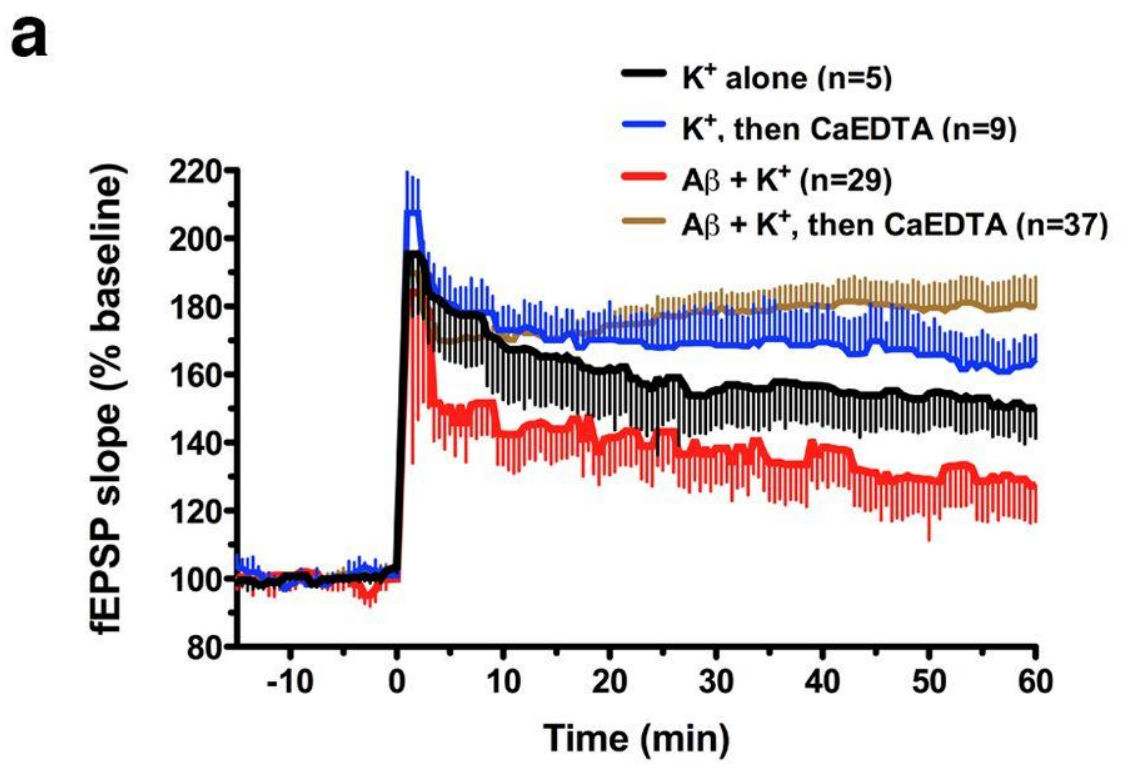


b
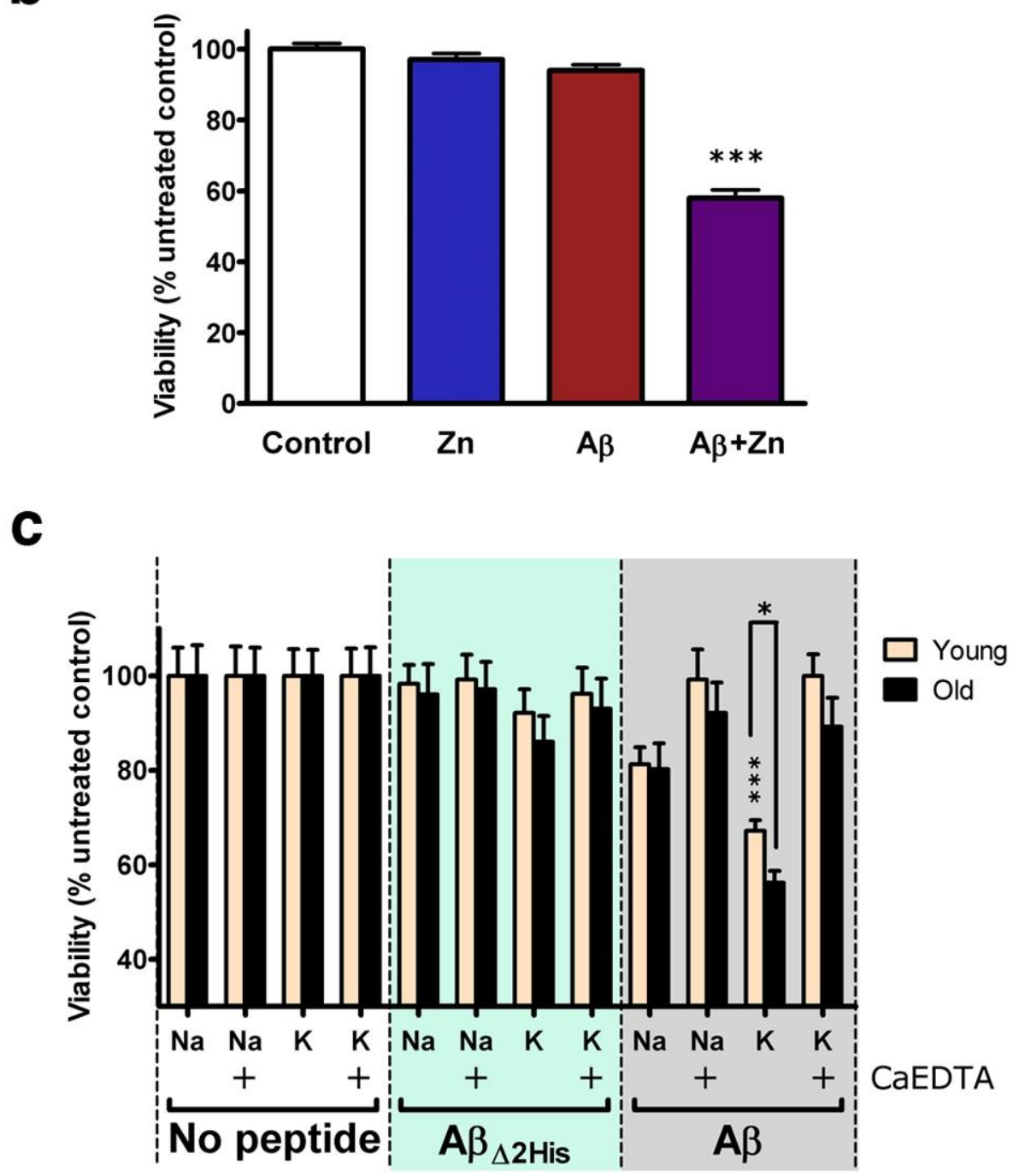

Figure 8. Effects of $\mathrm{Zn}^{2+}-A \beta$ complexes on acute hippocampal slice electrophysiology and viability. Data are means \pm SEM. (a) A $\beta$ suppression of LTP on depolarized tissue is rescued by $\mathrm{Zn}^{2+}$-chelation. (b) $\mathrm{Zn}^{2+}-A \beta$ complexes inhibit slice viability. $* * * p<0.001$, ANOVA post hoc Bonferroni, $n=10$

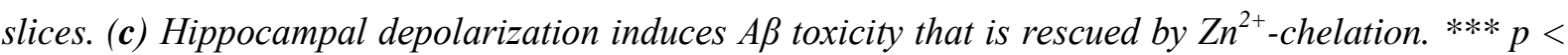
0.001, ANOVA post hoc Bonferroni; A $\beta$ inhibited viability only with depolarized tissue $\left(^{*} p<0.05\right.$, tissue from 65-weeks-old rats was more affected, $n=30$ slices for this comparison), which was rescued by $\mathrm{Zn}^{2+}$-chelation.

Slices treated with $\mathrm{A} \beta(15 \mu \mathrm{M})+$ high $\mathrm{K}^{+}$showed markedly impaired LTP compared to slices treated with high $\mathrm{K}^{+}$alone (Fig. 8a). CaEDTA, added to slices after $\mathrm{A} \beta / \mathrm{high} \mathrm{K}^{+}$ 
treatment, reverted this LTP suppression (Fig. 8a), as well as in the case of $\mathrm{Zn}^{2+}$-induced A $\beta$ aggregates (Figs. 6a and 7a).

Next, we tested the toxicity of $\mathrm{Zn}^{2+}$-induced $\mathrm{A} \beta(1-42)$ aggregates in this timeframe by adding $\mathrm{A} \beta(1-42) \pm \mathrm{Zn}^{2+}$ (both $15 \mu \mathrm{M}$ ) to acute hippocampal slices that had not been exposed to high $\mathrm{K}^{+}$. MTT assay of the slices indicated that, after 3 -hour treatment, $\mathrm{Zn}^{2+}$ or $\mathrm{A} \beta$ alone did not inhibit viability, but the combination of them was markedly toxic (Fig. 8b). To determine whether the toxicity of $\mathrm{A} \beta$ could be induced by endogenous $\mathrm{Zn}^{2+}$, we performed MTT viability assays on hippocampal slices (the treatment was the same as in the LTP studies, Fig. 8a) in ExViS chamber. A $\beta$ induced toxicity only occurred with high $\mathrm{K}^{+}$where the slices were expected to release $\mathrm{Zn}^{2+}$ (Fig. 8c). The toxicity was abolished by CaEDTA added after the high $\mathrm{K}^{+}$treatment (Fig. 8c), consistent with the disaggregation of $\mathrm{Zn}^{2+}$ induced $\mathrm{A} \beta$ aggregates (Figs. $6 \mathrm{a} \& 7 \mathrm{a}$ ). $\mathrm{A} \beta_{\Delta 2 \mathrm{His}}$ was not toxic with high $\mathrm{K}^{+}$(Fig. 8c), due to its inability to form $\mathrm{Zn}^{2+}$-induced aggregates (Figs. 6a \& 7a). The responses of old (65weeks-old) and young (10-weeks-old) male hippocampi were compared. The viability of the older tissue was only significantly more impaired after high $\mathrm{K}^{+}$exposure (Fig. 8c), consistent with greater $A \beta$ aggregation induced by high $\mathrm{K}^{+}$(Fig. 7b), the higher extracellular $\mathrm{Zn}^{2+}$ levels released by older hippocampi upon high $\mathrm{K}^{+}$exposure (Fig. 4b) and their slower reuptake of $\mathrm{Zn}^{2+}$ (Fig. 5c,d).

\subsubsection{Zinc-induced $A \beta(1-42)$ oligomers attach and enter neurons}

To investigate the mechanism of $\mathrm{Zn}^{2+}$-induced toxicity of $\mathrm{A} \beta$, we analyzed the slices treated with the bis-ANS indicator by fluorescence microscopy. Slices from young rats treated with $\mathrm{A} \beta(1-42)(50 \mu \mathrm{M})$ and high $\mathrm{K}^{+}$, as in Figure $7 \mathrm{a}$, were washed with $\mathrm{H}$-ACSF to remove unbound $A \beta$, showed strong fluorescence on neurons but not glia in the granule cell layer, CA3 pyramidal cell layer, as well as hilar pyramidal neurons and the mossy fibers (Fig. 9a-e). To determine whether this fluorescence was due to $A \beta(1-42)$ adhering to the surface, we studied the effects of carbonate $\mathrm{pH} 12$ washing of the slices after being treated with $\mathrm{A} \beta(1-42)$ and high $\mathrm{K}^{+}$. This technique for stripping surface-bound polypeptides indeed decreased but did not terminate the bis-ANS signal (Fig. 9f,g). The fluorescence we detected was not nonspecific fluorescence from bound bis-ANS since tissue without added A $\beta$, but incubated with 
bis-ANS, was not fluorescent under these conditions (Fig. 10a). We studied the possible intraneuronal localization of $A \beta$ by confocal microscopy. This required unfixed tissue, because fixation removes bis-ANS fluorescence. PI staining was used to label the cell nuclei. Bis-ANS fluorescence was only identified within neurons treated with $\mathrm{A} \beta+\mathrm{Zn}^{2+}$, not with $\mathrm{A} \beta$ or $\mathrm{Zn}^{2+}$ alone (Fig. 9h-k), and co-localized with PI. Taken together, these findings indicate that $\mathrm{Zn}^{2+}$-induced $\mathrm{A} \beta$ oligomers can bind to and enter hippocampal neurons.
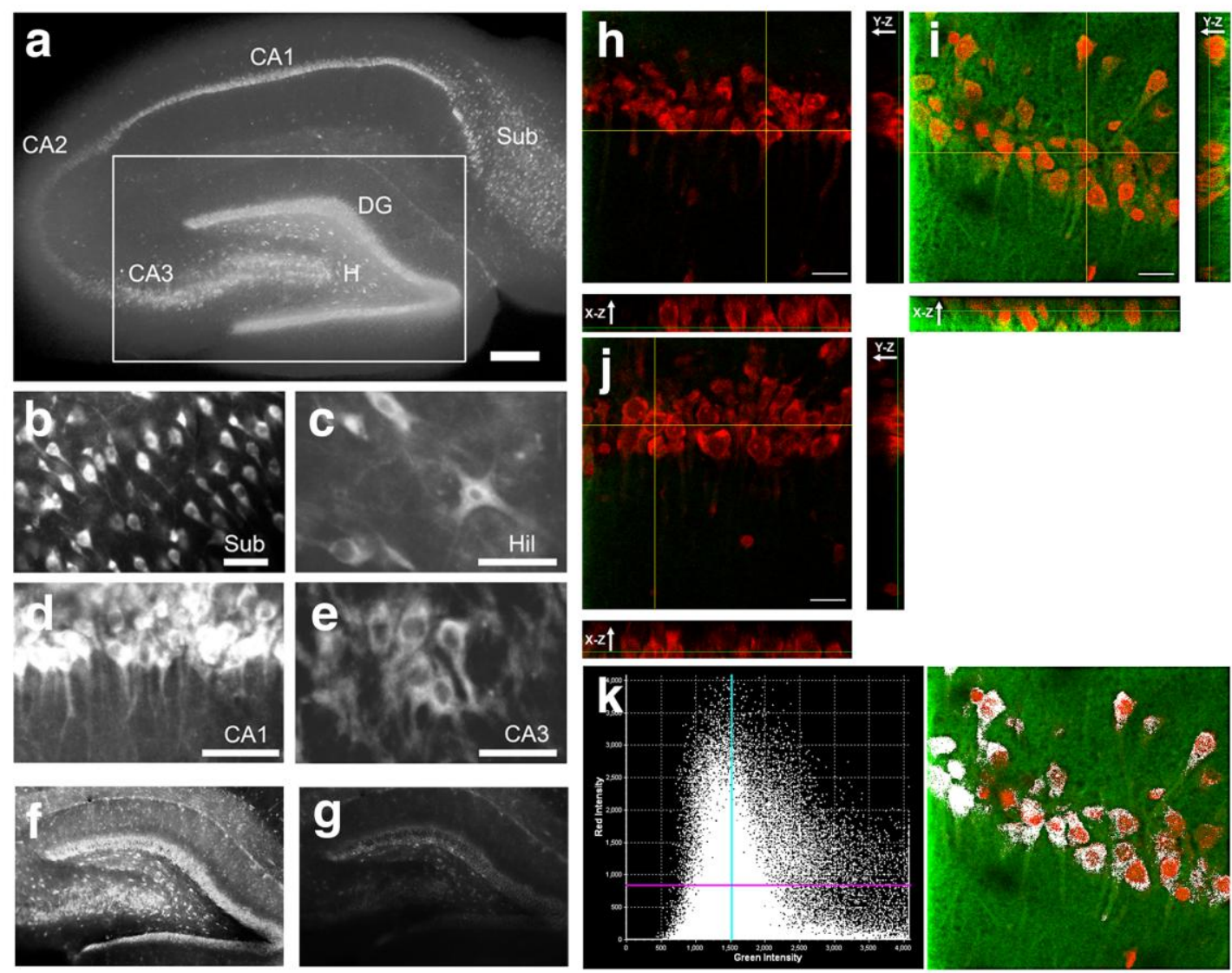

Figure 9. Bis-ANS fluorescence of adherent Aß(1-42) predominantly on neurons of acute hippocampal slices. (a) Image of bis-ANS labeling of a complete slice. Scale bar $=300 \mu \mathrm{m}$. (b-e) Enlargements of subiculum, hilus, CA1 and CA3 pyramidal cell layer showing that bis-ANS detects neurons but not glia. Scale bar $=50 \mu \mathrm{m}$. (f),(g) Effect of carbonate wash on bis-ANS labeling. The slices were prepared as for (a), but after washing off the unbound bis-ANS, the slices were washed with either (f), ACSF or (g) $110 \mathrm{mM} \mathrm{NaCl}, 50 \mathrm{mM} \mathrm{Na} \mathrm{CO}_{3}, \mathrm{pH}=12$, for $5 \mathrm{~min}$, and then washed twice with ACSF before microscopy. (h-l) Confocal reconstruction of unfixed slices in the $x y, x z$, and $y z$ planes of the CA1 pyramidal cell layer are shown following staining with propidium iodide (red) for 
intracellular nucleic acids and bis-ANS (green) for AB(1-42) oligomers. Scale bar $=20 \mu \mathrm{m}$. (h) Treatment with $A \beta(1-42)$, no $\mathrm{Zn}^{2+}$; (i) $A \beta(1-42)+\mathrm{Zn}^{2+}(50 \mu \mathrm{M})$; (j) $\mathrm{Zn}^{2+}$ alone (50 $\left.\mu \mathrm{M}\right)$; (k) colocalization plot of PI (red) and bis-ANS (green) with (right panel) a pseudo-color image of colocalized pixels (white). Data are each representative of $n=5$ slices.

We examined the attachment and neuronal entry of A $\beta$ oligomers following CaEDTA washing by bis-ANS fluorescence microscopy. Treatment with $\mathrm{A} \beta$ alone, which caused little aggregation or toxicity, was associated with only low level of bis-ANS fluorescence on the washed slices (Fig. 10b). However, depolarization of $\mathrm{A} \beta$-treated slices with $\mathrm{K}^{+}$, or aggregation of the $\mathrm{A} \beta$ with added $\mathrm{Zn}^{2+}$, both caused markedly increased bis-ANS fluorescence on the same, washed, hippocampal structures observed in Figure 9a (Fig. 10c,e). The increased adherence of bis-ANS-labeled A $\beta$ to hippocampus under these conditions was consistent with the increased aggregation and toxicity detected (Figs. 7a and 8b,c).

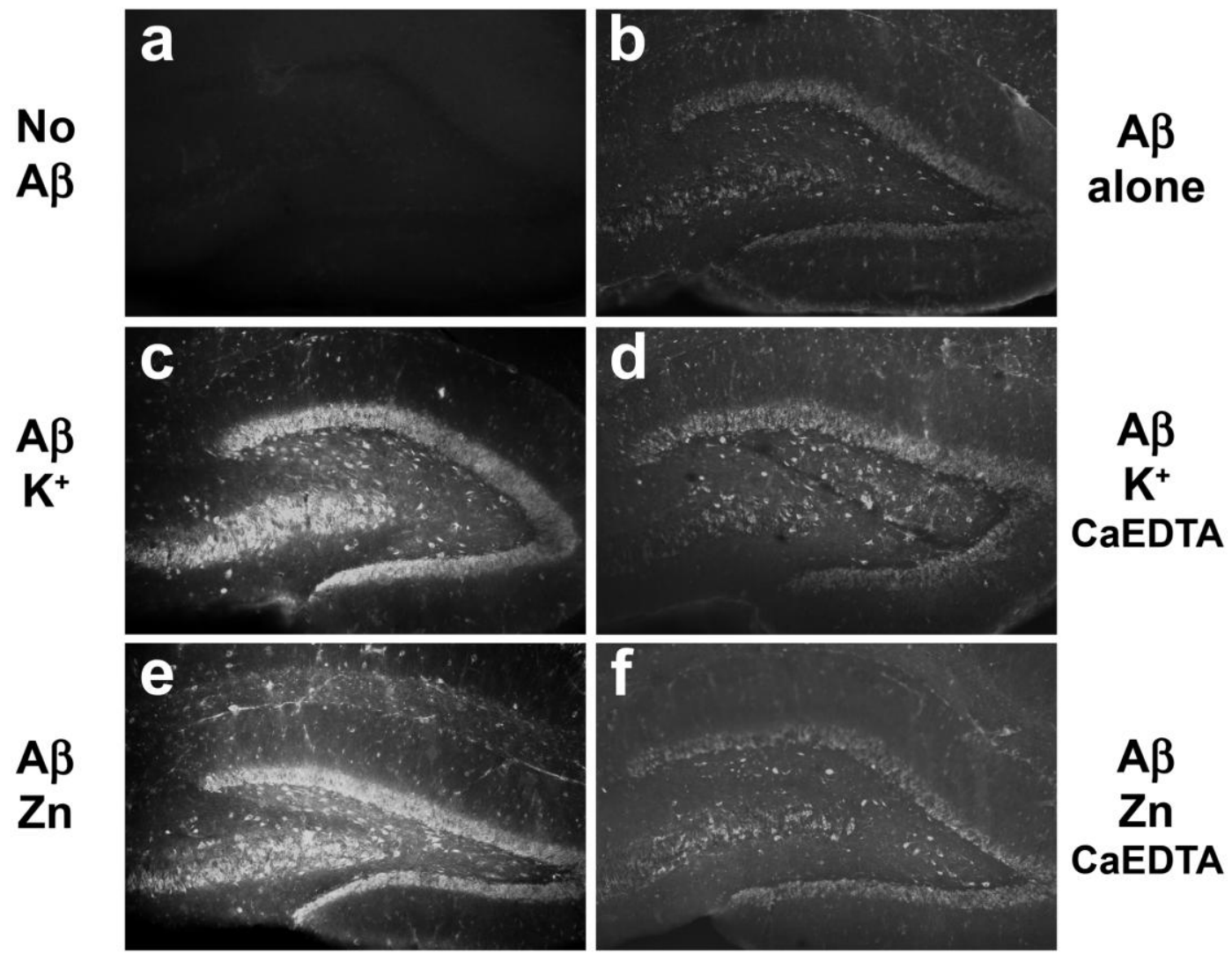

Figure 10. Bis-ANS fluorescence within acute hippocampal slices treated with Aß(1-42). The slices were treated with freshly prepared $A \beta(1-42)$ and prepared as for Figures 7 and $9\left( \pm 50 \mathrm{mM} \mathrm{K} \mathrm{K}^{+}\right.$or 50 
$\mu M \mathrm{Zn}^{2+}$ treatment, as indicated) but after washing off the unbound bis-ANS, the slices were washed with either (a-c), (e), ACSF or (d), (f), CaEDTA (0.5 mM in ACSF), for $5 \mathrm{~min}$, and then rinsed twice

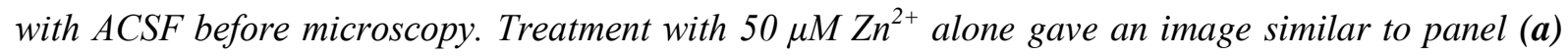
(see also Figure 9j).

CaEDTA decreased the toxicity of $\mathrm{A} \beta$ on slices induced by $\mathrm{K}^{+}$(Fig. 8a,c), reversed the aggregation of $\mathrm{A} \beta$ induced by $\mathrm{K}^{+}$in vivo (Fig. 7a), and $\mathrm{Zn}^{2+}$ in vitro (Fig. 6a, and chelates $\mathrm{Zn}^{2+}$ released from excited tissue (Fig. 4a). Toxicity is mediated by $\mathrm{Zn}^{2+}$-induced $\mathrm{A} \beta$ aggregates adhering to or entering neurons, $\mathrm{A} \beta$-treated slices treated with $\mathrm{K}^{+}$or $\mathrm{Zn}^{2+}$ and then washed with CaEDTA (Fig. 10d,f) showed much lower bis-ANS fluorescence than slices washed with ACSF (Fig. 10c,e). Slices that were first fixed with ethanol or formaldehyde and then treated, as above, with $\mathrm{A} \beta \pm$ high $\mathrm{K}^{+}$or $\mathrm{Zn}^{2+}$ did not label with bis-ANS (data not shown). This indicates that the $\mathrm{A} \beta: \mathrm{Zn}^{2+}$ complexes only adhere to living neurons. Therefore, it is not possible to examine fixed human or APP transgenic mouse tissue using bis-ANS staining.

\subsection{Experiments on the role of $\alpha$-synuclein in $A \beta$ aggregation}

To explore whether other factors could influence the aggregation propensity of $A \beta$ we investigated the synergistic effect of the $\mathrm{A} \beta$ and the intracellular aggregation-prone protein $\alpha$ synuclein $(\alpha \mathrm{SN})$ which, according to the recent findings, may interact with $\mathrm{A} \beta$. Via this interaction $\mathrm{A} \beta$ and $\alpha \mathrm{SN}$ could promote each other's aggregation. For these studies we have taken the advantage of an $\alpha \mathrm{SN}$ overexpressing SH-SY5Y cell line and investigated the effects of the above mentioned synergistic peptide-protein interaction by treating the cells with synthetic $A \beta(1-42$.

\subsubsection{Phenotypic characterization of $\alpha \mathrm{SN}$ normal and overexpresing cell lines}

Eight days after plating, differentiated normal (NE) and differentiated overexpressing (OE) showed different distribution and shape as investigated by transmission light microscopy at $200 \times$ magnification (Fig. 11). OE cells showed lower cell density, while 
synaptogenesis and neurite growth have been enhanced compared to the NE cells. Neurite lengths of NE cells were increased after differentiation, and interestingly a marked slowdown could be seen in cell metabolism of $\alpha \mathrm{SN}$ OE cells (data not shown).
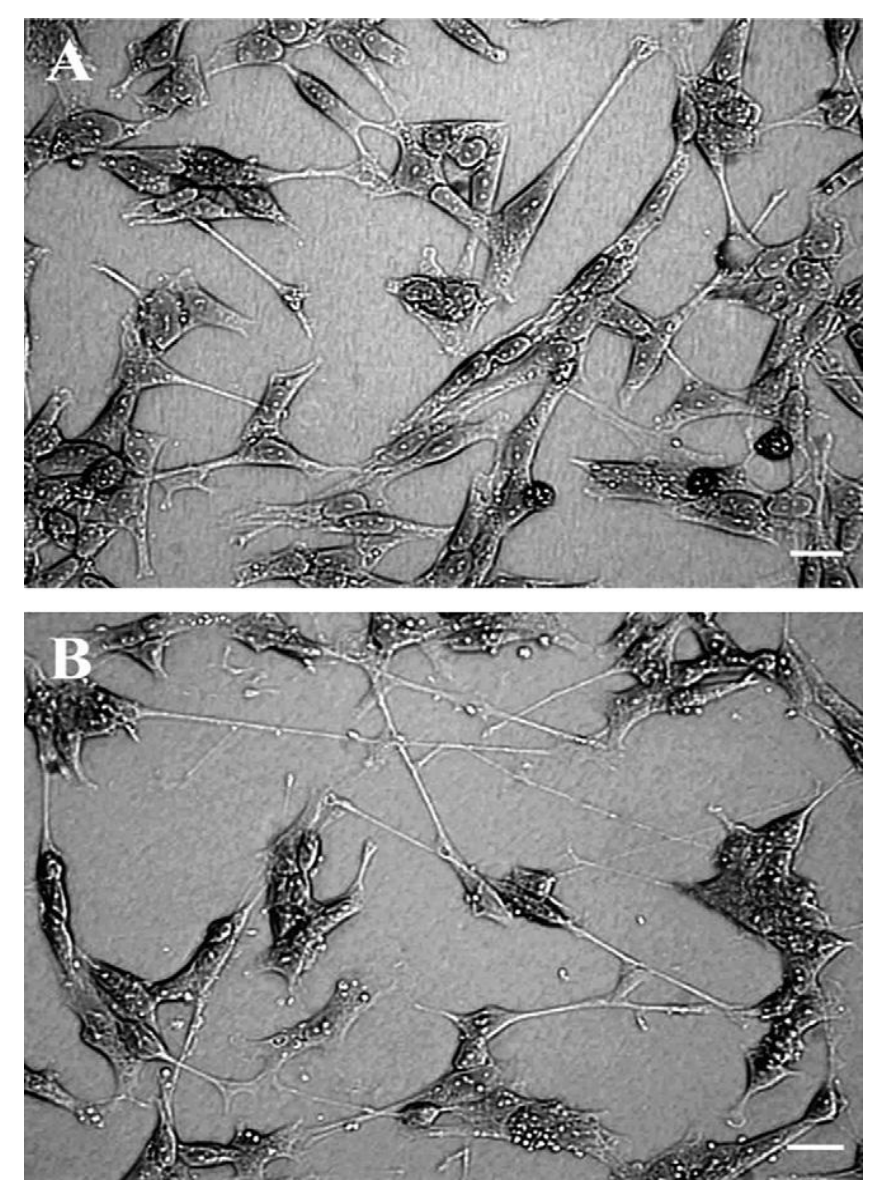

Figure 11. Snapshots of aSN normal and overexpressing SH-SY5Y cell lines in transmission light. (A) Differentiated aSN normal expressing (NE) cells; (B) differentiated $\alpha S N$ overexpressing $(O E)$ cells. Scale bar $30 \mu \mathrm{m}$.

\subsubsection{Measurement of proliferation kinetics with MTT assay}

Kinetics of cell proliferation were investigated by MTT assay using an initial cell number of $2 \times 10^{5} / \mathrm{ml}$ from non-differentiated cells. The kinetics were monitored up to 4 days after culturing. NE cells showed significant MTT reduction capacity already on day 2 $(n=21)$, compared to NE cells (Fig. 12). 


\section{Non-differentiated SH-SY5Y neuroblastoma cells}

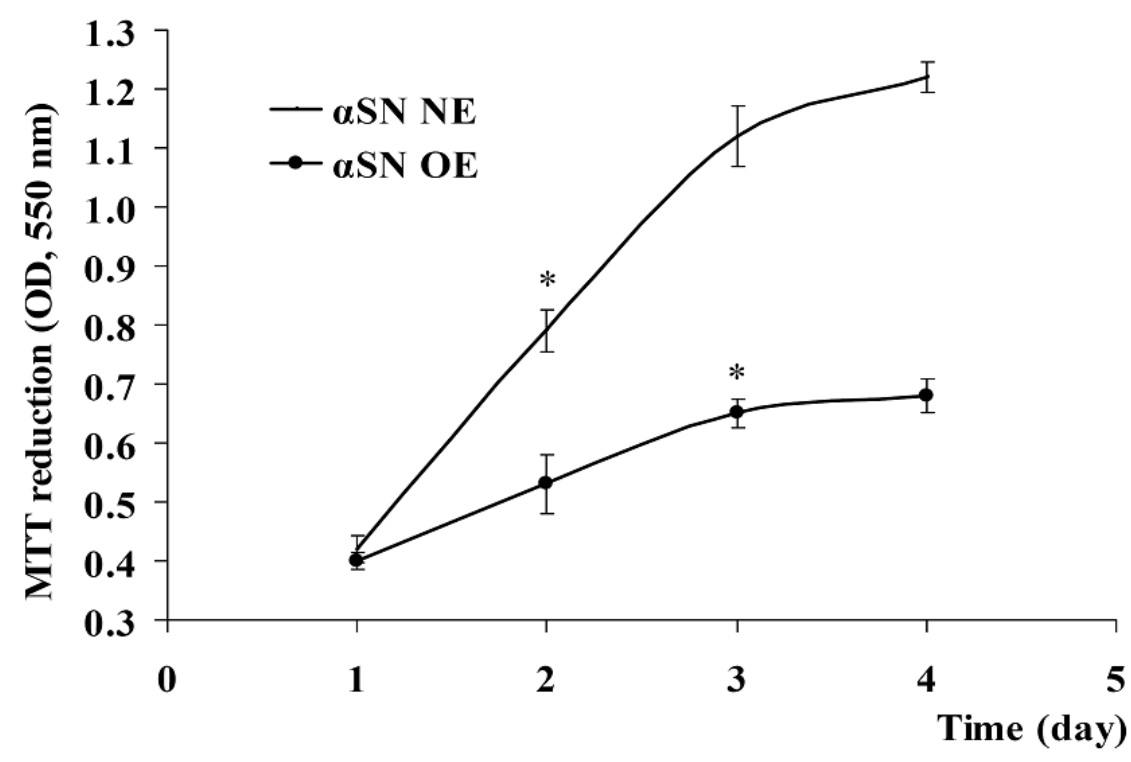

Figure 12. Proliferation kinetics of non-differentiated $N E$ and $O E$ cell measured by MTT assay using an initial cell number of $2 \times 10^{5} / \mathbf{m l} . \alpha S N=$ alpha-synuclein protein, $N E=$ alpha-synuclein normal expressing; $O E=$ alpha-synuclein overexpressing. Data are expressed as means \pm S.E.M. Differences $\left(^{*}\right)$ compared with the untreated control values $(0 \mathrm{~min})$ are significant at a level $p \leq 0.01$, $n=21$. Statistical analysis by ANOVA post hoc test, Bonferroni.

\subsubsection{Western blot analysis of $\alpha S N$}

The $\alpha \mathrm{SN}$ protein expression level of differentiated NE and OE cells was determined by Western blot analysis (Fig. 13). Immunoreactive bands were detected at the molecular weight of $19 \mathrm{kDa}$ in the samples of both cell lines, which proved the presence of the wild type monomeric $\alpha \mathrm{SN}$ protein (Fig. 13A). Moreover, the sample from OE cells showed a welldefined band at the molecular weight of approximately $24-26 \mathrm{kDa}$, which indicated a covalently modified isoform of $\alpha \mathrm{SN}$ protein (Fig. 13A). Two types of covalently modified $\alpha \mathrm{SN}$ isoform have been reported: the $O$-glycosylated (Shimura et al., 2001) and the monoubiquitinated form (Hasegawa et al., 2002). The result of the $\alpha \mathrm{SN}$ protein content 
analysis confirmed, that under the same conditions the $\alpha \mathrm{SN}$ protein expression in $\mathrm{OE}$ cells was significantly higher than in NE counterparts (Fig. 13B and C).
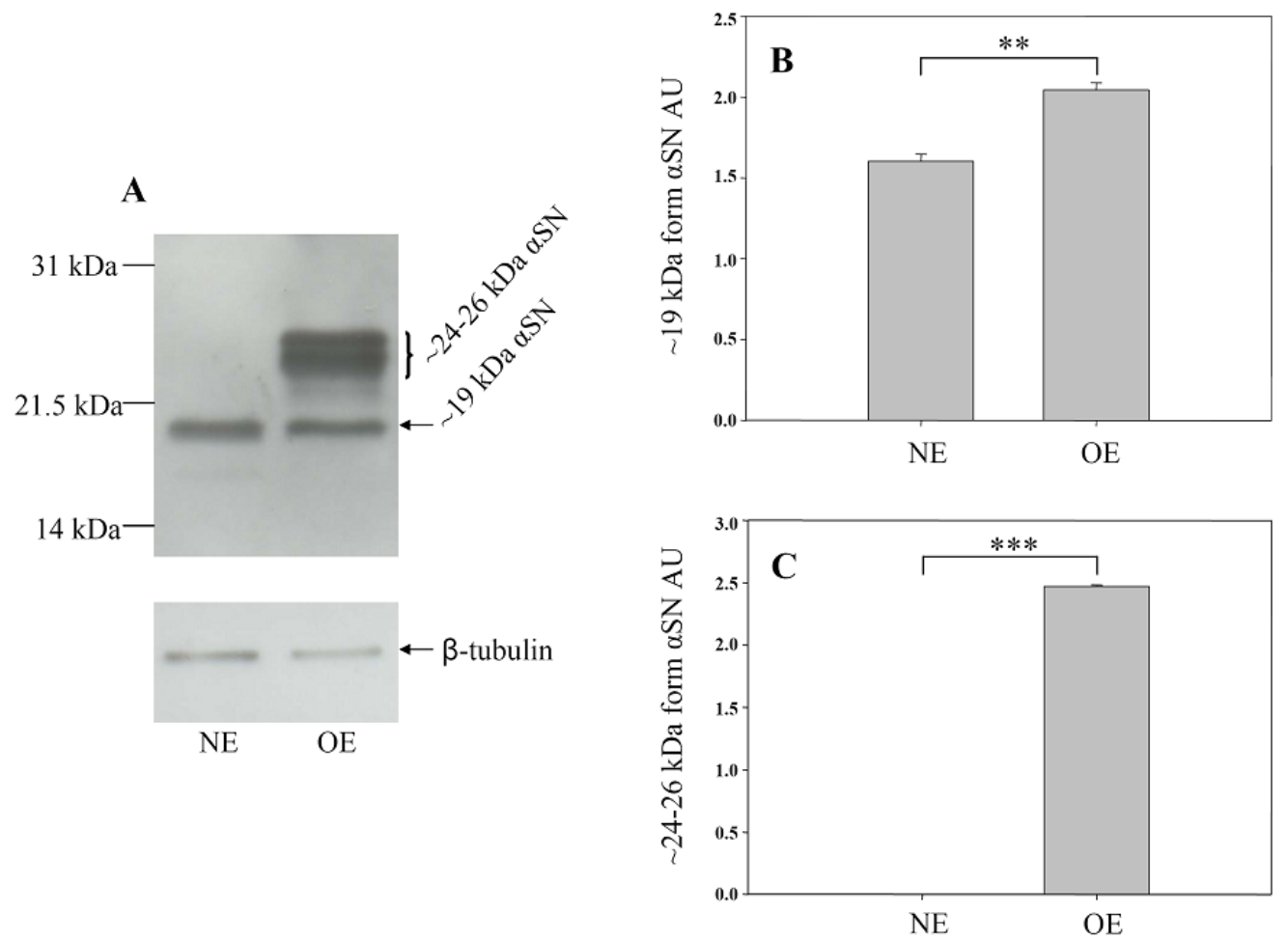

Figure 13. Comparison of aSN levels of aSN normal and overexpressing neuroblastoma cell lines. (A) Western blots show representative aSN levels. (B) $\sim 19 \mathrm{kDa}$ monomer aSN levels of normal (NE) and overexpressing $(O E)$ neuroblastoma cells. $(C) \sim 24-26 \mathrm{kDa}$ monomer $\alpha S N$ levels of $N E$ and $O E$ neuroblastoma cells. $\alpha S N=$ alpha-synuclein protein; $A U=$ arbitrary unit. Data are means $\pm S E M$, $n=3$. Asterisks indicate significant difference between $N E$ and $O E$ cells $\left({ }^{*} p \leq 0.05 ; * * p \leq 0.01\right.$; ***p $<$ 0.001; unpaired Student's $t$-test)

\subsubsection{The effects of $A \beta(1-42)$ and NAC on cell viability}

Differentiated cells were treated with protofibrillar and fibrillar $\mathrm{A} \beta(1-42)$ or NAC, and MTT assay was performed for detecting the cell viability. Data were expressed as percentage of non-treated control value (not shown). Even protofibrillar and fibrillar $A \beta(1-42)$ was toxic to NE cells, i.e., NE cells exhibited $57 \pm 5.6 \%$ and $49 \pm 8.3 \%$ viability after 1 and 8 days, 
respectively $(n=21)$. Moreover, $A \beta(1-42)$ caused more dramatic decrease in cell viability of OE cells, i.e., OE cells exhibited $31 \pm 4.9 \%$ and $25 \pm 7.3 \%$ viability after 1 and 8 days, respectively $(\mathrm{n}=21)$. NAC peptide was not toxic to either cell type after $1 \mathrm{~h}$ aggregation, however, after 8 day pre-aggregation it became markedly toxic, especially on OE cells (32 $\pm 3.7 \%$ viability) (Fig. 14).

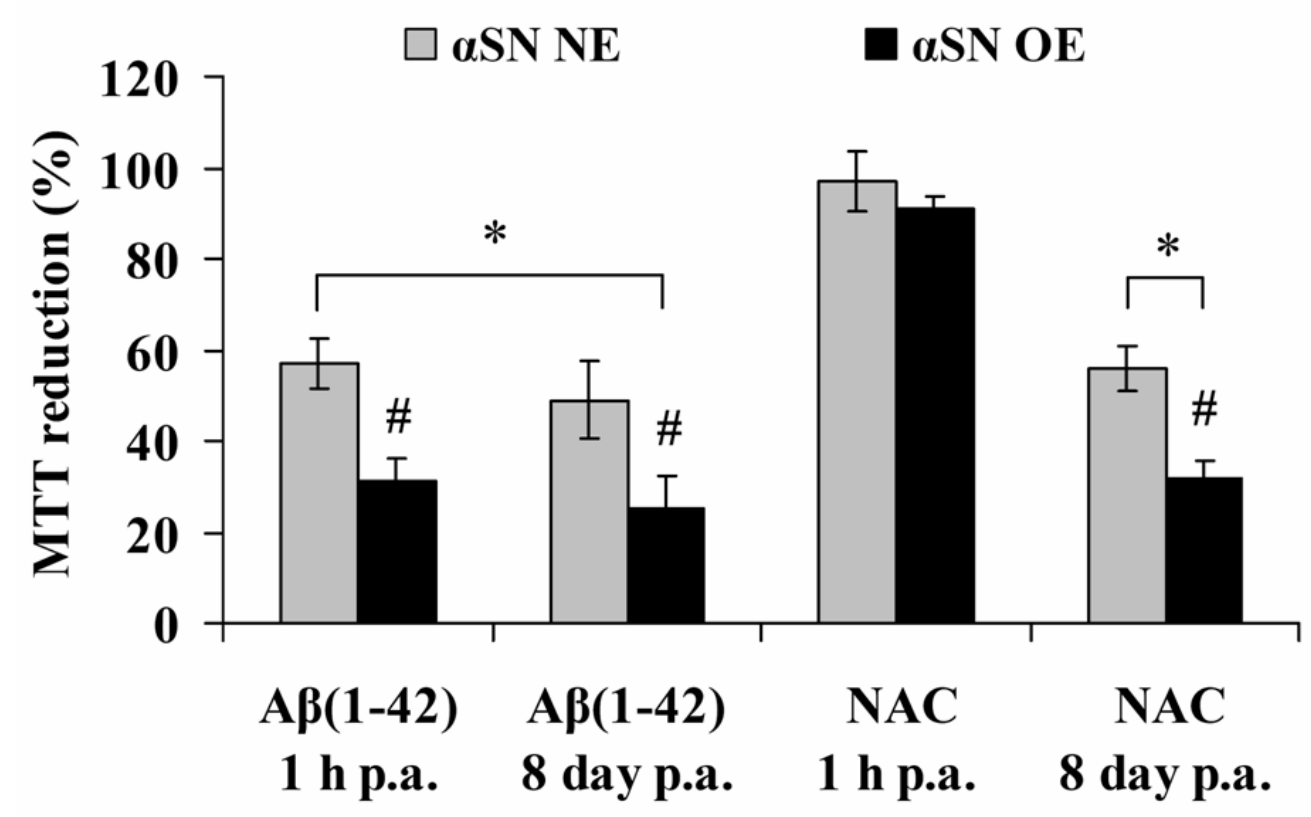

Figure 14. The effects of the treatment with various aggregating state of AB(1-42) and NAC peptides on NE and OE cell lines measured with MTT assay. The initial cell number was $2 \times 10^{5} / \mathrm{ml}$ in both cell lines. $\alpha S N=$ alpha-synuclein protein; p.a. = pre-aggregated Differences $\left(^{*}\right)$ compared to the non-treated control values (100\%) and differences (\#) compared to the aSN NE neuroblastoma cell values are significant at a level $p \unlhd 0.05, n=21$. Statistical analysis by ANOVA post hoc test, Bonferroni.

\subsubsection{The effects of classical apoptotic factors on cell viability}

To investigate whether the marked decrease in cell viability of OE cells is due to the altered $\mathrm{A} \beta$ aggregation caused by the elevated amount of $\alpha \mathrm{SN}$ or the OE became totally vulnerable to every stressor, we determined the cytotoxic effect of three different classical apoptotic molecules using MTT assay. After $\mathrm{H}_{2} \mathrm{O}_{2}$, amphotericin $\mathrm{B}$ and ruthenium red 
treatment, the viability of NE cells reduced to approximately $50 \%$ of the untreated control $\left(\mathrm{IC}_{50}, \mathrm{n}=21\right)$. Remarkably, $\alpha \mathrm{SN}$ OE cells were less sensitive to cell damage caused by these agents than the NE counterparts, which can be explained by the anti-apoptotic effect of $\alpha \mathrm{SN} .\left(75 \pm 5.9 \%\right.$ for $\mathrm{H}_{2} \mathrm{O}_{2}, 62 \pm 7.9 \%$ for amphotericin $\mathrm{B}$ and $87 \pm 7.1 \%$ for ruthenium red, $\mathrm{n}=21)$ (Fig. 15).

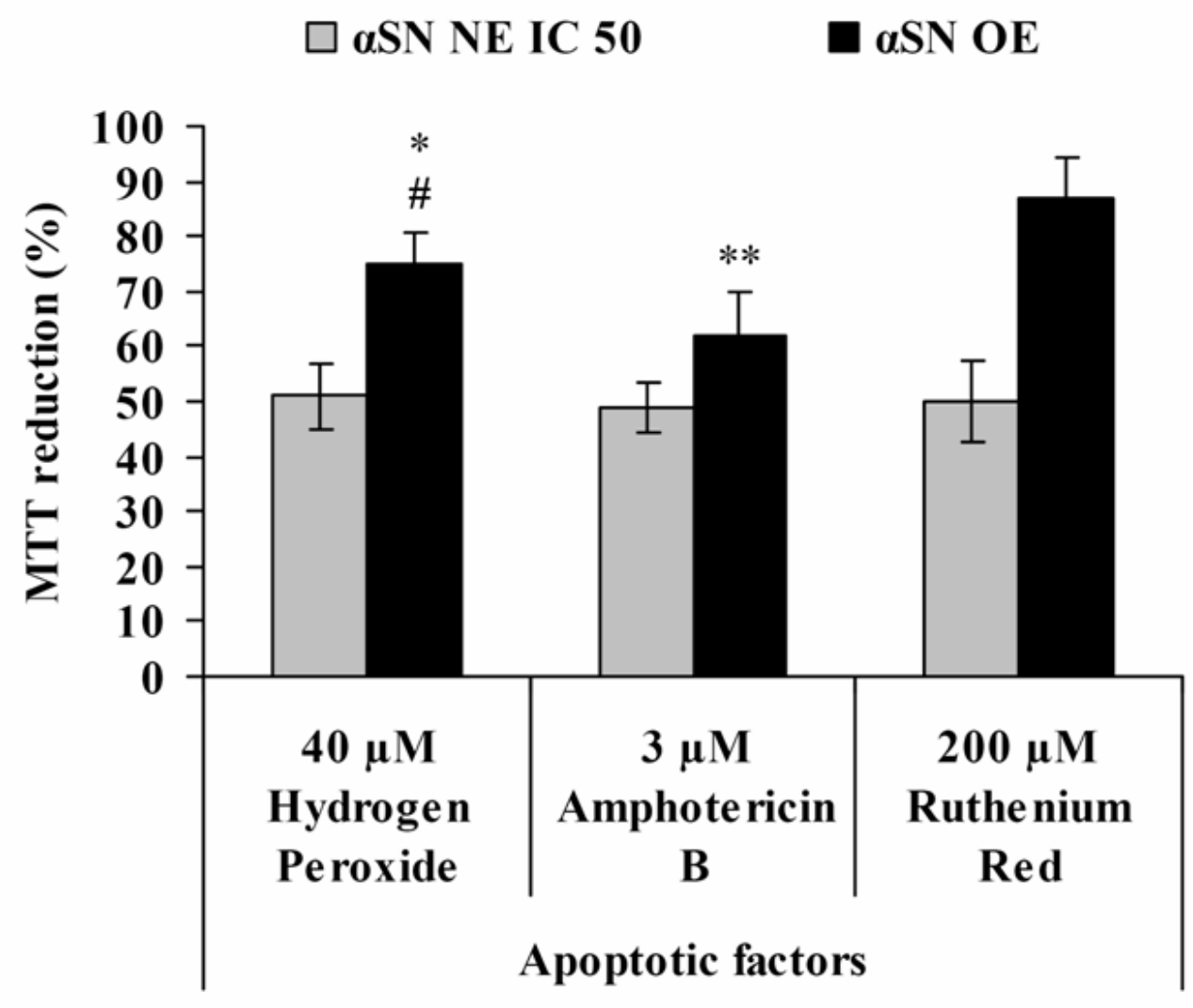

Figure 15. Differentiated NE and OE cells treated with classical apoptotic factors. Cell viability was determined by MTT assay. Alpha-synuclein protected the OE cells from cell damage caused by these compounds. $\alpha S N=$ alpha-synuclein protein; $N E=$ alpha-synuclein normal expressing; $O E=$ alphasynuclein overexpressing; p.a. = pre-aggregated. Differences compared to the $I C_{50}$ values are significant at a level $p \leq 0.01(*)$, or at $p \leq 0.001(* *) ; n=21$. Statistical analysis by ANOVA post hoc test, Bonferroni. 


\section{Discussion}

It is the first time, to our knowledge, that $\mathrm{Zn}^{2+}$-induced $\mathrm{A} \beta$ aggregation has been characterized by bis-ANS or analytical ultracentrifugation (Fig. 6). The results showed that, over a short time, the reaction yields toxic $A \beta$ oligomers and they formed much faster than by spontaneous aggregation (Ferrao-Gonzales et al., 2005). We demonstrated that $A \beta(1-42)$ could be aggregated into bis-ANS reactive species within seconds by endogenous $\mathrm{Zn}^{2+}$ released from hippocampus (Fig. 7a), and that LTP and mitochondrial activity are inhibited as a consequence (Fig. 8). Previous studies found that $\mathrm{Zn}^{2+}$ inhibited the toxicity of $\mathrm{A} \beta(1-42)$ in dissociated cell culture (Cuajungco et al., 2000). However, these experiments were performed over a much longer time-frame (e.g. 48 hours), which was enough for $\mathrm{Zn}^{2+}$ and $\mathrm{A} \beta$ to form amyloid fibrils (Bush et al., 1994b) which are much less toxic than oligomers (FerraoGonzales et al., 2005, Hung et al., 2008). In contrast, we found that $\mathrm{Zn}^{2+}$-induced aggregates of A $\beta$ were toxic to hippocampal slices within 3 hours (Fig. 8b,c), and inhibited LTP within 1 hour (Fig. 8a). The rate of $\mathrm{A} \beta$ aggregation into oligomers (but not fibrils) correlates with toxicity (Hung et al., 2008), therefore $\mathrm{Zn}^{2+}$ may support toxicity by accelerating the rate of $\mathrm{A} \beta$ aggregation.

Moreover, bis-ANS detects a toxic, soluble A $\beta(1-42)$ oligomer species that are similar to soluble ADDL-oligomers that have been reported to play key role in AD pathogenesis (Gong et al., 2003, Barghorn et al., 2005, Kayed and Glabe, 2006, Noguchi et al., 2009). The 13.8 S (est. MW $300 \mathrm{kDa}$ ) species of $\mathrm{A} \beta$ :bis- ANS formed by $\mathrm{Zn}^{2+}$ (Fig. 6e) has a very similar size and molecular weight to the recently found native-amylospheroids (ASPD) oligomeric species from human brain (Noguchi et al., 2009) and to the previously reported ADDLs (a well-characterized oligomeric preparation of $A \beta$ ) analyzed by sedimentation velocity technique under similar conditions (Hepler et al., 2006). The ADDLs were reported to have a size distribution that ranged from 4-12 S. Like ADDLs, the $\mathrm{Zn}^{2+}$-induced $\mathrm{A} \beta$ oligomers were markedly neurotoxic (Fig. 8) and bound to the surface of neurons (Figs. $9 \& 10$ ). Our results indicate that $\mathrm{Zn}^{2+}$ promotes and accelerates the formation of neurotoxic ADDL-like highorder diffusible oligomers. ADDLs require 24 hours preincubation (Lambert et al., 2001), whereas we found $\mathrm{Zn}^{2+}$-induced $\mathrm{A} \beta(1-42)$ oligomers to be toxic within 3 hours (Fig. 8). 
Additionally, in our studies a specific form of $\mathrm{A} \beta(1-42)$ induced by $\mathrm{Zn}^{2+}$ appears to enter neurons immediately, because even low concentrations $(<0.5 \mu \mathrm{M})$ were sufficient to detect them within the neurons. We deduce this concentration from the proportion of $\mathrm{A} \beta(1-$ 42) that remains bound to bis-ANS from the reaction of $50 \mu \mathrm{M} \mathrm{A} \beta(1-42)$ with $50 \mu \mathrm{M} \mathrm{Zn^{2+ }}$ in vitro (Fig. 6d,e). This form of $\mathrm{Zn}^{2+}$-modified soluble $\mathrm{A} \beta$, which is small enough $(<20 \mathrm{~nm})$ to enter the synaptic cleft and has 5-fold higher binding affinity to bis-ANS (Fig. 6d,e) is a candidate for an especially neurotoxic species that is induced by $\mathrm{Zn}^{2+}$ in our studies (Fig. 8).

The bis-ANS fluorescent $A \beta(1-42)$ aggregates attached exclusively to neurons (Fig. 9). The neuron-specific deposition of $A \beta$ that we observed using bis-ANS is rather similar to toxic soluble $A \beta$ oligomers species that selectively deposit on neuronal dendrites (Barghorn et al., 2005) and specifically at NMDA-containing synapses (De Felice et al., 2007). It is important that the highest concentrations of intracellular $\mathrm{Zn}^{2+}$ have been detected by fluorophores in the hilus (Kay, 2003). In our study bis-ANS detected $\mathrm{Zn}^{2+}$ - mediated attachment of $A \beta(1-42)$ to non-hilar structures such as the granule cell layer of the dentate gyrus (Figs. 9 and 10). Therefore, $\mathrm{A} \beta$ oligomers are not attaching to the slices merely at sites of highest intracellular $\mathrm{Zn}^{2+}$ concentration.. The distribution of $\mathrm{A} \beta$ detected by bis-ANS corresponds to the distribution of the NR2B subunit of the NMDA receptor (Petralia et al., 1994), which was reported to be the binding site of $A \beta(1-42)$ oligomers attracted to the $\mathrm{Zn}^{2+}$ (Deshpande et al., 2009) that is released upon activation as a co-transmitter with glutamate (Qian and Noebels, 2005). Our findings are therefore consistent with $\mathrm{Zn}^{2+}$-dependent adherence of $\mathrm{A} \beta$ to the NR2B subunit. NR2B has a $\mathrm{Zn}^{2+}$ binding site that allosterically modulates the NMDA channel. Therapeutic drugs such as Clioquinol and Memantine are blocking A $\beta(1-42)$ to bind to NR2B (Deshpande et al., 2009). This may also explain why the peptide was not removed from slices by washing with ACSF, but was removed by pH 12 and by chelation with CaEDTA (Figs. $9 \& 10$ ).

The mechanism of LTP inhibition (Fig. 8a) could be interpret by the blockade of the NMDA receptor or intrinsic toxicity of $\mathrm{Zn}^{2+}$-induced $\mathrm{A} \beta$ oligomers (Fig. 8b,c). It is also possible that the growing $A \beta$ mass at the synapse has the potential to disrupt synaptic physiology by chelating $\mathrm{Zn}^{2+}$, which is crucial for the normal function of the NMDA receptor and hereby LTP formation (Lu et al., 2000, Li et al., 2001, Qian and Noebels, 2005, Adlard et al., 2010). Soluble $A \beta$ monomers bind one equivalent of $\mathrm{Zn}^{2+}$ with low micromolar affinity 
(Danielsson et al., 2007), but oligomeric $\mathrm{A} \beta$ binds up to $\approx 3.0$ equivalents of $\mathrm{Zn}^{2+}$ under physiological conditions (Atwood et al., 2000). With time $\mathrm{A} \beta$ oligomers may fuse into $\mathrm{Zn}^{2+}$ filled fibrillar amyloid plaques (Lovell et al., 1998, Cherny et al., 1999), which are less toxic than oligomers (Cuajungco et al., 2000). The possibility that $\mathrm{A} \beta$ toxicity is enhanced by $\mathrm{Cu}^{2+}$ (Opazo et al., 2002) released from the activated glutamatergic synapses (Schlief et al., 2005) is not excluded by our current findings.

These data provide evidence for altered extracellular $\mathrm{Zn}^{2+}$ regulation potentially explaining age and gender as risk factors for AD. We hypothesize that as a consequence of energy depletion with aging (Shigenaga et al., 1994), the tissue does not efficiently reassimilate $\mathrm{Zn}^{2+}$ release during neurotransmission (Fig. 5c-e), and it causes metallostasis (increased average extracellular $\mathrm{Zn}^{2+}$ concentrations), which leads to $\mathrm{A} \beta$ aggregation (Fig. 5). $\mathrm{A} \beta$ is also released by synaptic activity (Cirrito et al., 2003), therefore $\mathrm{A} \beta$ and $\mathrm{Zn}^{2+}$ could be very close to each other in the extracellular space, for that reason the reuptake mechanisms have high importance to prevent $\mathrm{Zn}^{2+}$ and $\mathrm{A} \beta$ from reacting. We observed that extracellular $\mathrm{A} \beta$ prevents $\mathrm{Zn}^{2+}$ from entering the tissue (Fig. 5f), possibly contributing to an intracellular zinc-deficiency in $\mathrm{AD}$. We also observed that $\mathrm{Zn}^{2+}$-induced $\mathrm{A} \beta$ aggregates suppress mitochondrial activity (Fig. 8b,c), which could lead to further impairment of energydependent $\mathrm{Zn}^{2+}$ uptake and so a vicious cycle could emerge (Fig. 16).
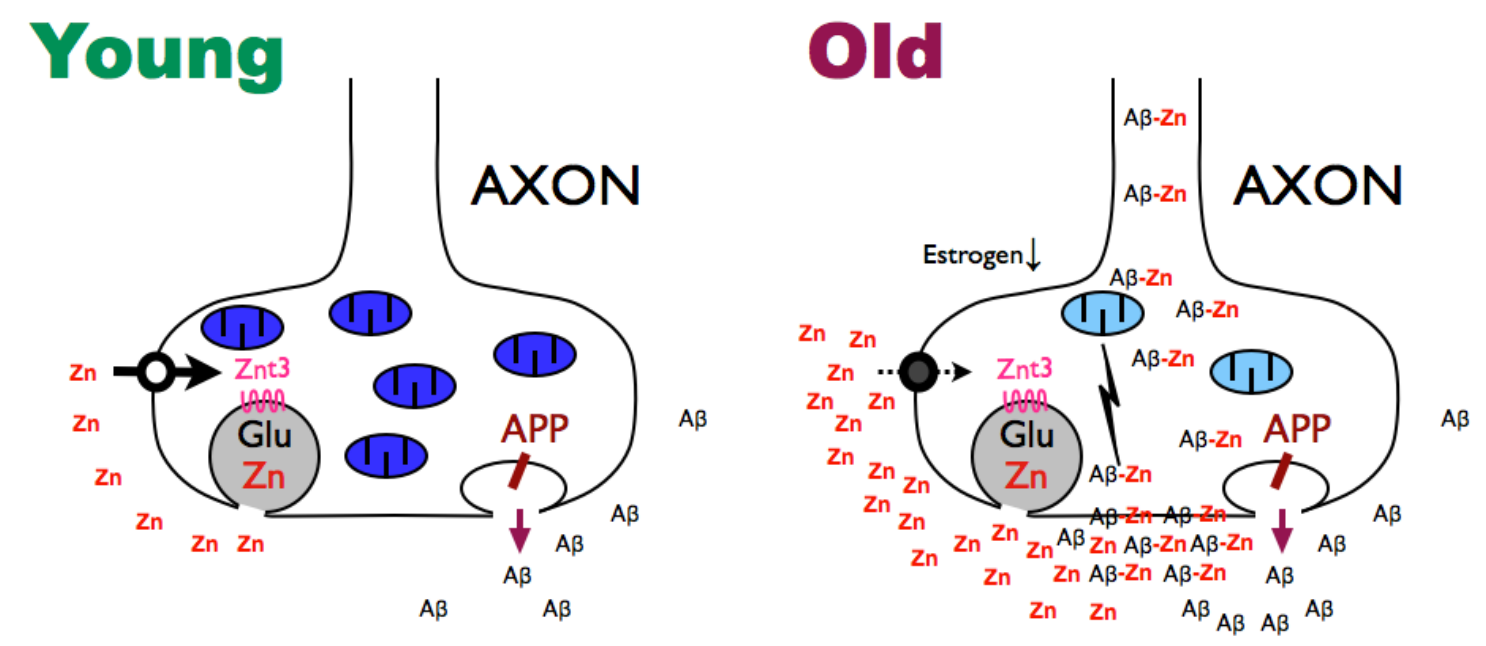

Figure 16. Model for synaptic $\mathrm{Zn}^{2+}$ release in the pathogenesis of AD. $\mathrm{Zn}^{2+}$ is released upon synaptic activity, and is normally rapidly taken up by energy dependent mechanisms. With age, mitochondrial energy is decreased, leading to more sluggish reuptake of extracellular $\mathrm{Zn}^{2+}$. This allows $\mathrm{Zn}^{2+}$ to react 
with $A \beta$, which is also released into the same vicinity by an activity-dependent mechanism. We have found that $\mathrm{A} \beta-\mathrm{Zn}^{2+}$ complexes adhere to and are taken up by neurons, and inhibit mitochondrial activity. This will further suppress the uptake of $\mathrm{Zn}^{2+}$, leading to a vicious cycle.

While the released $\mathrm{Zn}^{2+}$ levels upon slice activation were increased with age in both female and male tissue, the extracellular $\mathrm{Zn}^{2+}$ concentrations achieved were significantly higher for older females than older males (Fig. 4b). While this increase was only $\approx 20 \%$, the age-adjusted risk of $\mathrm{AD}$ in females is only 1.56 times higher compared to males (Gao et al., 1998). Therefore, the modestly increased risk for $\mathrm{AD}$ in females is proportional to the modestly increased release of $\mathrm{Zn}^{2+}$. This gender difference was not due to greater uptake fatigue in older females (Fig. 5d). Hence, female rat hippocampal tissue must possess a greater capacity to release $\mathrm{Zn}^{2+}$ upon synaptic activation with age, which is consistent with the reported higher levels of releasable $\mathrm{Zn}^{2+}$ only becoming evident with aging in female mouse hippocampus (Lee et al., 2002). Exchangeable $\mathrm{Zn}^{2+}$ levels increase with age in female mouse hippocampi because decreased estrogen induces an increase in ZnT3 protein levels (Lee et al., 2004). Consistent with those previous findings, we now present the first experimental data that, with age, activity-dependent $\mathrm{Zn}^{2+}$ release can induce increased $\mathrm{A} \beta$ aggregation in females (Figs. 4b and 7b).

We have developed a new and simple model for AD that recapitulates changes with aging and gender of direct relevance to neurochemical changes that drive the actual disease pathology. These findings may explain why the knockdown of ZnT3 abolishes both amyloid deposition and the increased in amyloid level in females seen in APP transgenic mouse brain (Lee et al., 2002). We observed that the classical $\mathrm{Zn}^{2+}$-ionophore, pyrithione, corrected the inhibition of $\mathrm{Zn}^{2+}$ uptake caused by ageing (Figure 5d). This result is similar to the proposed therapeutic mechanism of ionophores like Clioquinol and PBT2, which rapidly reversed cognitive loss in APP transgenic mice (Adlard et al., 2008) and induced cognitive benefit within 12 weeks in a recent phase 2 clinical trial in AD patients (Lannfelt et al., 2008).

As a part of our investigations we were searching for other $\mathrm{Zn}^{2+}$-independent factors, which exert totally different synergistic effect to $A \beta$ aggregation (e.g. peptide - protein instead of peptide - metal interactions). Starting from the principle that $\alpha \mathrm{SN}$ is an intracellular aggregation-prone protein, and extracellular $A \beta$ is able to penetrate into the neurons (Bahr et al., 1998, Kanekiyo and Bu, 2009, Fuentealba et al., 2010), we supposed that they can meet, 
interact and synergistically promote each other's aggregation. Moreover, recent studies revealed that there are close connections between AD and PD (Lewis et al., 2010) and the appearance of $\mathrm{AD}$ and PD symptoms are often mixed, establishing the Lewy body variant of Alzheimer's disease. Based on these, it was reasonable for us to investigate together $\mathrm{A} \beta, \alpha \mathrm{SN}$ and their interactions.

We have compared the viability of cells expressing normal (NE), or elevated amount (OE) of $\alpha \mathrm{SN}$ exposed to various stressors. The overexpression of $\alpha \mathrm{SN}$ was proven by Western-blot analysis. Interestingly, OE cells had decreased sensitivity to classical apoptotic compounds, in contrast aggregated, disease-related peptides caused more serious damage to this cell line, compared to NE. Furthermore, aSN OE cells showed altered phenotype, their neurite lengths and arborisation increased, accompanied by decreased cell motility.

It is already known from the literature, that increased level of $\alpha \mathrm{SN}$ impairs microtubule-dependent trafficking (Lee et al., 2006), which may result in the altered phenotype we observed (Rui et al., 2006). Moreover, the proliferation rate of OE cells slowed down compared to NE cells. This can be explained by the direct toxic effect of abnormal $\alpha \mathrm{SN}$ level (Kumar et al., 2005), or alternatively, by the inhibition of cell-division in OE cells (Winner et al., 2004).

Recent findings indicate that programmed cell death could contribute to Parkinson's disease pathogenesis (Mattson, 2006), moreover, insufficient regulation of $\alpha \mathrm{SN}$ may induce apoptosis (Kumar et al., 2005). On the other hand, our results and several recent reports (da Costa et al., 2000, Manning-Bog et al., 2003, Vartiainen et al., 2006) demonstrated the antiapoptotic, or neuroprotective property of wild-type $\alpha \mathrm{SN}$ overexpression. One possible explanation of this is the chaperon-like activity of $\alpha \mathrm{SN}$ (da Costa et al., 2000), since $\alpha \mathrm{SN}$ shows a $40 \%$ homology with members of the 14-3-3 chaperone protein family (Ostrerova et al., 1999). Consequently, $\alpha \mathrm{SN}$ may interact with some participant of apoptotic pathways, preventing the progress of programmed cell death. Surprisingly, $\alpha \mathrm{SN}$ OE cells were more sensitive to aggregated $A \beta(1-42)$ and NAC treatment than the NE counterparts. Most probably, aggregated peptides and apoptotic factors activated different apoptotic pathways, or the overexpression of $\alpha \mathrm{SN}$ resulted in an altered stress response. $\mathrm{A} \beta(1-42)$ and NAC may cause the hyperphosphorylation and aggregation of tau protein (Zheng et al., 2002, BlurtonJones and Laferla, 2006), which subsequently promotes aSN aggregation (Giasson et al., 
2003), and ultimately leads to the breakdown of the microtubule system. In addition, tau and $\alpha \mathrm{SN}$ can synergistically promote each other's aggregation and fibrillarization (Giasson et al., 2003, Duka et al., 2006), however, each protein prefers the homopolymeric form instead of heteropolymeric filaments (Giasson et al., 2003). This phenomenon can be more serious in the OE cells, which are containing elevated level of $\alpha \mathrm{SN}$ from the beginning, thus $\mathrm{A} \beta(1-42)$ may cause a more extensive devastation. Consistent with this theory, as we described earlier, the damaging effect of exogenous $\mathrm{A} \beta(1-42)$ on SH-SY5Y cells depends on the level of arborisation (Datki et al., 2004). More expanded neurite arborisation is accompanied by highly developed microtubule system, and elevated level of tau protein, therefore exogenous aggregated $\mathrm{A} \beta$-triggered intracellular tau and $\alpha \mathrm{SN}$ may cause a more severe cellular damage.

Classical apoptotic factors, which we used in this study, did not induce hyperphosphorylation and aggregation of tau or $\alpha \mathrm{SN}$ directly. Amphotericin $\mathrm{B}$ is an ionophore, which causes $\mathrm{K}^{+}$leakage and subsequent apoptotic pathway activation (Fujii et al., 1997, Varlam et al., 2001). Ruthenium red serves as a calcium channel blocker, which disrupts mitochondrial $\mathrm{Ca}^{2+}$-homeostasis (Cibulsky and Sather, 1999), while $\mathrm{H}_{2} \mathrm{O}_{2}$ causes massive oxidative stress and damage. On the other hand, aggregated peptides affect the microtubule system, facilitating tau aggregation, which eventually leads to $\alpha \mathrm{SN}$ aggregation.

We conclude that aging alters $\mathrm{Zn}^{2+}$ dynamics within rat acute hippocampal slices in a manner that could explain why aging is the major risk factor for $\mathrm{AD} . \mathrm{Zn}^{2+}$-release from slices induced by high $\mathrm{K}^{+}$was significantly higher in case of older (65-week-old) compared to 10week-old rats, and it is more pronounced in females. This was associated with slower uptake of extracellular $\mathrm{Zn}^{2+}$ in older slices, and recapitulated by mild mitochondrial intoxication of younger ones. $\mathrm{Zn}^{2+}: \mathrm{A} \beta(1-42)$ aggregates were toxic to slices, under conditions where $\mathrm{A} \beta$ alone was not. In addition, $\alpha \mathrm{SN}$ overexpression alters the neuronal phenotype and protects cells from classical apoptotic compounds, while it makes cells more vulnerable to aggregated $\mathrm{A} \beta(1-42)$ and NAC. This phenomenon indicates that there are synergistic interactions between $\alpha \mathrm{SN}$ and $\mathrm{A} \beta$ aggregation, and vice versa. Accordingly $\mathrm{A} \beta$ aggregation (and therefore $\mathrm{AD})$ seems to be a multifactorial event, which makes difficult to find a convenient single-drug therapeutic solution. 


\section{Summary}

In this section, I would like to summarize all the novel findings of my Ph.D work:

- We developed the ExViS device for maintaining and treating tissue slices in small working volume.

- We developed a high throughput screening method to follow the $\mathrm{Zn}^{2+}$ release and uptake in hippocampal slices.

- First time in the literature, we proved that endogenous $\mathrm{Zn}^{2+}$ can precipitate exogenous $\mathrm{A} \beta$.

- We confirmed that the $\mathrm{Zn}^{2+}-\mathrm{A} \beta$ complex is neurotoxic and inhibits normal neuronal functions.

- We shoved the gender and age dependency of hippocampal $\mathrm{Zn}^{2+}$ release.

- We demonstrated that $\mathrm{Zn}^{2+}$ chelators could be suitable drug candidates for preventing A $\beta$ toxicity.

- We proved that $\mathrm{A} \beta$ and $\alpha \mathrm{SN}$ can synergistically enhance neurotoxicity.

\section{Acknowledgements}

I am grateful to Prof. Dr. Botond Penke for allowing me to join his research group and for a lot of help and support during my Ph.D. work.

I would like to express my gratitude to Dr. Zsolt László Datki for scientific guidance, encouragement and support.

I would like to thank everyone who helped me to perform these experiments and provided useful technical support: Dr. István Földi, Dr. Viktor Szegedi, Dr. Gábor Juhász, Dr. Bozsó Zsolt, Dr. Márta Zarándi, Dr Lívia Fülöp, Dr. Katalin Soós, Dr. Dóra Simon, Emese Mózes, Mónika Mihók and Mária Batki.

Special thanks to the Australian collaborator Ahley Bush and his research group for a lot of help, and also for performing the analytical ultracentrifugation experiments. 
I would like to thank all members of the Alzheimer's Disease Research Group and the Department of Medical Chemistry.

Finally, I am especially thankful to my wife Orsolya Hodula and my family for their love and encouragement.

The research was supported by the following grants: National Research Foundation OTKA TS049817, NKFP 2A/005/2004 OM-00424/2004 (MediChem 2). KPI-NKTH E. Teller grant; BP: RET-DNT 08/2004, OTKA NK 73672, Memoload FP-7 201159, FP-7 211696, TAMOP-4.2.2.-08/1/2008-002. 


\section{References}

Adlard PA, Cherny RA, Finkelstein DI, Gautier E, Robb E, Cortes M, Volitakis I, Liu X, Smith JP, Perez K, Laughton K, Li QX, Charman SA, Nicolazzo JA, Wilkins S, Deleva K, Lynch T, Kok G, Ritchie CW, Tanzi RE, Cappai R, Masters CL, Barnham KJ, Bush AI (2008) Rapid restoration of cognition in Alzheimer's transgenic mice with 8-hydroxy quinoline analogs is associated with decreased interstitial Abeta. Neuron 59:43-55.

Adlard PA, Parncutt JM, Finkelstein DI, Bush AI (2010) Cognitive loss in zinc transporter-3 knock-out mice: a phenocopy for the synaptic and memory deficits of Alzheimer's disease? The Journal of neuroscience : the official journal of the Society for Neuroscience 30:1631-1636.

Aniksztejn L, Charton G, Ben-Ari Y (1987) Selective release of endogenous zinc from the hippocampal mossy fibers in situ. Brain Res 404:58-64.

Assaf SY, Chung SH (1984) Release of endogenous Zn2+ from brain tissue during activity. Nature 308:734-736.

Atwood CS, Scarpa RC, Huang X, Moir RD, Jones WD, Fairlie DP, Tanzi RE, Bush AI (2000) Characterization of copper interactions with alzheimer amyloid beta peptides: identification of an attomolar-affinity copper binding site on amyloid beta1-42. Journal of neurochemistry 75:1219-1233.

Bahr BA, Hoffman KB, Yang AJ, Hess US, Glabe CG, Lynch G (1998) Amyloid beta protein is internalized selectively by hippocampal field CA1 and causes neurons to accumulate amyloidogenic carboxyterminal fragments of the amyloid precursor protein. J Comp Neurol 397:139-147.

Bancila V, Nikonenko I, Dunant Y, Bloc A (2004) Zinc inhibits glutamate release via activation of pre-synaptic $K$ channels and reduces ischaemic damage in rat hippocampus. Journal of neurochemistry 90:1243-1250.

Barghorn S, Nimmrich V, Striebinger A, Krantz C, Keller P, Janson B, Bahr M, Schmidt M, Bitner RS, Harlan J, Barlow E, Ebert U, Hillen H (2005) Globular amyloid betapeptide oligomer - a homogenous and stable neuropathological protein in Alzheimer's disease. Journal of neurochemistry 95:834-847.

Bayer TA, Jakala P, Hartmann T, Havas L, McLean C, Culvenor JG, Li QX, Masters CL, Falkai P, Beyreuther K (1999) Alpha-synuclein accumulates in Lewy bodies in Parkinson's disease and dementia with Lewy bodies but not in Alzheimer's disease beta-amyloid plaque cores. Neurosci Lett 266:213-216.

Besser L, Chorin E, Sekler I, Silverman WF, Atkin S, Russell JT, Hershfinkel M (2009) Synaptically released zinc triggers metabotropic signaling via a zinc-sensing receptor in the hippocampus. The Journal of neuroscience : the official journal of the Society for Neuroscience 29:2890-2901.

Bettger WJ, O'Dell BL (1981) A critical physiological role of zinc in the structure and function of biomembranes. Life Sci 28:1425-1438.

Bitanihirwe BK, Cunningham MG (2009) Zinc: the brain's dark horse. Synapse 63:10291049.

Blennow K, de Leon MJ, Zetterberg H (2006) Alzheimer's disease. Lancet 368:387-403.

Blurton-Jones M, Laferla FM (2006) Pathways by which Abeta facilitates tau pathology. Curr Alzheimer Res 3:437-448. 
Bozso Z, Penke B, Simon D, Laczko I, Juhasz G, Szegedi V, Kasza A, Soos K, Hetenyi A, Weber E, Tohati H, Csete M, Zarandi M, Fulop L (2010) Controlled in situ preparation of A beta(1-42) oligomers from the isopeptide "iso-A beta(1-42)", physicochemical and biological characterization. Peptides 31:248-256.

Braak E, Griffing K, Arai K, Bohl J, Bratzke H, Braak H (1999) Neuropathology of Alzheimer's disease: what is new since A. Alzheimer? Eur Arch Psychiatry Clin Neurosci 249 Suppl 3:14-22.

Buchman VL, Hunter HJ, Pinon LG, Thompson J, Privalova EM, Ninkina NN, Davies AM (1998) Persyn, a member of the synuclein family, has a distinct pattern of expression in the developing nervous system. The Journal of neuroscience : the official journal of the Society for Neuroscience 18:9335-9341.

Budde T, Minta A, White JA, Kay AR (1997) Imaging free zinc in synaptic terminals in live hippocampal slices. Neuroscience 79:347-358.

Burre J, Sharma M, Tsetsenis T, Buchman V, Etherton MR, Sudhof TC (2010) Alphasynuclein promotes SNARE-complex assembly in vivo and in vitro. Science 329:1663-1667.

Bush AI (2003) The metallobiology of Alzheimer's disease. Trends Neurosci 26:207-214.

Bush AI, Pettingell WH, Jr., Paradis MD, Tanzi RE (1994a) Modulation of A beta adhesiveness and secretase site cleavage by zinc. The Journal of biological chemistry 269:12152-12158.

Bush AI, Pettingell WH, Multhaup G, d Paradis M, Vonsattel JP, Gusella JF, Beyreuther K, Masters CL, Tanzi RE (1994b) Rapid induction of Alzheimer A beta amyloid formation by zinc. Science 265:1464-1467.

Callahan MJ, Lipinski WJ, Bian F, Durham RA, Pack A, Walker LC (2001) Augmented senile plaque load in aged female beta-amyloid precursor protein-transgenic mice. The American journal of pathology 158:1173-1177.

Carson JA, Turner AJ (2002) Beta-amyloid catabolism: roles for neprilysin (NEP) and other metallopeptidases? Journal of neurochemistry 81:1-8.

Charton G, Rovira C, Ben-Ari Y, Leviel V (1985) Spontaneous and evoked release of endogenous $\mathrm{Zn} 2+$ in the hippocampal mossy fiber zone of the rat in situ. Experimental brain research Experimentelle Hirnforschung Experimentation cerebrale 58:202-205.

Cherny RA, Atwood CS, Xilinas ME, Gray DN, Jones WD, McLean CA, Barnham KJ, Volitakis I, Fraser FW, Kim Y, Huang X, Goldstein LE, Moir RD, Lim JT, Beyreuther K, Zheng H, Tanzi RE, Masters CL, Bush AI (2001) Treatment with a copper-zinc chelator markedly and rapidly inhibits beta-amyloid accumulation in Alzheimer's disease transgenic mice. Neuron 30:665-676.

Cherny RA, Legg JT, McLean CA, Fairlie DP, Huang X, Atwood CS, Beyreuther K, Tanzi RE, Masters CL, Bush AI (1999) Aqueous dissolution of Alzheimer's disease Abeta amyloid deposits by biometal depletion. The Journal of biological chemistry 274:23223-23228.

Choi DW, Yokoyama M, Koh J (1988) Zinc neurotoxicity in cortical cell culture. Neuroscience 24:67-79.

Chorin E, Vinograd O, Fleidervish I, Gilad D, Herrmann S, Sekler I, Aizenman E, Hershfinkel M (2011) Upregulation of KCC2 activity by zinc-mediated neurotransmission via the $\mathrm{mZnR} / \mathrm{GPR} 39$ receptor. The Journal of neuroscience : the official journal of the Society for Neuroscience 31:12916-12926. 
Cibulsky SM, Sather WA (1999) Block by ruthenium red of cloned neuronal voltage-gated calcium channels. The Journal of pharmacology and experimental therapeutics 289:1447-1453.

Cirrito JR, Kang JE, Lee J, Stewart FR, Verges DK, Silverio LM, Bu G, Mennerick S, Holtzman DM (2008) Endocytosis is required for synaptic activity-dependent release of amyloid-beta in vivo. Neuron 58:42-51.

Cirrito JR, May PC, O'Dell MA, Taylor JW, Parsadanian M, Cramer JW, Audia JE, Nissen JS, Bales KR, Paul SM, DeMattos RB, Holtzman DM (2003) In vivo assessment of brain interstitial fluid with microdialysis reveals plaque-associated changes in amyloid-beta metabolism and half-life. The Journal of neuroscience : the official journal of the Society for Neuroscience 23:8844-8853.

Colvin RA, Bush AI, Volitakis I, Fontaine CP, Thomas D, Kikuchi K, Holmes WR (2008) Insights into $\mathrm{Zn} 2+$ homeostasis in neurons from experimental and modeling studies. Am J Physiol Cell Physiol 294:C726-742.

Cooper AA, Gitler AD, Cashikar A, Haynes CM, Hill KJ, Bhullar B, Liu K, Xu K, Strathearn KE, Liu F, Cao S, Caldwell KA, Caldwell GA, Marsischky G, Kolodner RD, Labaer J, Rochet JC, Bonini NM, Lindquist S (2006) Alpha-synuclein blocks ER-Golgi traffic and Rab1 rescues neuron loss in Parkinson's models. Science 313:324-328.

Cote A, Chiasson M, Peralta MR, 3rd, Lafortune K, Pellegrini L, Toth K (2005) Cell typespecific action of seizure-induced intracellular zinc accumulation in the rat hippocampus. The Journal of physiology 566:821-837.

Cuajungco MP, Goldstein LE, Nunomura A, Smith MA, Lim JT, Atwood CS, Huang X, Farrag YW, Perry G, Bush AI (2000) Evidence that the beta-amyloid plaques of Alzheimer's disease represent the redox-silencing and entombment of abeta by zinc. The Journal of biological chemistry 275:19439-19442.

Culvenor JG, McLean CA, Cutt S, Campbell BC, Maher F, Jakala P, Hartmann T, Beyreuther K, Masters CL, Li QX (1999) Non-Abeta component of Alzheimer's disease amyloid (NAC) revisited. NAC and alpha-synuclein are not associated with Abeta amyloid. The American journal of pathology 155:1173-1181.

da Costa CA, Ancolio K, Checler F (2000) Wild-type but not Parkinson's disease-related ala53 --> Thr mutant alpha -synuclein protects neuronal cells from apoptotic stimuli. The Journal of biological chemistry 275:24065-24069.

Danielsson J, Pierattelli R, Banci L, Graslund A (2007) High-resolution NMR studies of the zinc-binding site of the Alzheimer's amyloid beta-peptide. The FEBS journal 274:4659.

Datki Z, Juhasz A, Galfi M, Soos K, Papp R, Zadori D, Penke B (2003) Method for measuring neurotoxicity of aggregating polypeptides with the MTT assay on differentiated neuroblastoma cells. Brain Res Bull 62:223-229.

Datki Z, Papp R, Zadori D, Soos K, Fulop L, Juhasz A, Laskay G, Hetenyi C, Mihalik E, Zarandi M, Penke B (2004) In vitro model of neurotoxicity of Abeta 1-42 and neuroprotection by a pentapeptide: irreversible events during the first hour. Neurobiol Dis 17:507-515.

Datki ZL, Hunya A, Penke B (2007) A novel and simple fluorescence method for the measurement of presynaptic vesicular zinc release in acute hippocampal slices with a fluorescence plate reader. Brain Res Bull 74:183-187.

Davies L, Wolska B, Hilbich C, Multhaup G, Martins R, Simms G, Beyreuther K, Masters CL (1988) A4 amyloid protein deposition and the diagnosis of Alzheimer's disease: 
prevalence in aged brains determined by immunocytochemistry compared with conventional neuropathologic techniques. Neurology 38:1688-1693.

De Felice FG, Velasco PT, Lambert MP, Viola K, Fernandez SJ, Ferreira ST, Klein WL (2007) Abeta oligomers induce neuronal oxidative stress through an N-methyl-Daspartate receptor-dependent mechanism that is blocked by the Alzheimer drug memantine. The Journal of biological chemistry 282:11590-11601.

Deshpande A, Kawai H, Metherate R, Glabe CG, Busciglio J (2009) A role for synaptic zinc in activity-dependent Abeta oligomer formation and accumulation at excitatory synapses. The Journal of neuroscience : the official journal of the Society for Neuroscience 29:4004-4015.

Dickson DW (1997) The pathogenesis of senile plaques. J Neuropathol Exp Neurol 56:321339.

Dong J, Atwood CS, Anderson VE, Siedlak SL, Smith MA, Perry G, Carey PR (2003) Metal binding and oxidation of amyloid-beta within isolated senile plaque cores: Raman microscopic evidence. Biochemistry 42:2768-2773.

Duka T, Rusnak M, Drolet RE, Duka V, Wersinger C, Goudreau JL, Sidhu A (2006) Alphasynuclein induces hyperphosphorylation of Tau in the MPTP model of parkinsonism. FASEB J 20:2302-2312.

Elrod-Erickson M, Benson TE, Pabo CO (1998) High-resolution structures of variant Zif268DNA complexes: implications for understanding zinc finger-DNA recognition. Structure 6:451-464.

Ferrao-Gonzales AD, Robbs BK, Moreau VH, Ferreira A, Juliano L, Valente AP, Almeida FC, Silva JL, Foguel D (2005) Controlling \{beta\}-amyloid oligomerization by the use of naphthalene sulfonates: trapping low molecular weight oligomeric species. The Journal of biological chemistry 280:34747-34754.

Flood F, Sundstrom E, Samuelsson EB, Wiehager B, Seiger A, Johnston JA, Cowburn RF (2004) Presenilin expression during induced differentiation of the human neuroblastoma SH-SY5Y cell line. Neurochemistry international 44:487-496.

Frederickson CJ, Giblin LJ, 3rd, Balaji RV, Masalha R, Zeng Y, Lopez EV, Koh JY, Chorin U, Besser L, Hershfinkel M, Li Y, Thompson RB, Krezel A (2006) Synaptic release of zinc from brain slices: factors governing release, imaging, and accurate calculation of concentration. Journal of neuroscience methods 154:19-29.

Frederickson CJ, Suh SW, Silva D, Thompson RB (2000) Importance of zinc in the central nervous system: the zinc-containing neuron. J Nutr 130:1471S-1483S.

Friedlich AL, Lee JY, van Groen T, Cherny RA, Volitakis I, Cole TB, Palmiter RD, Koh JY, Bush AI (2004) Neuronal zinc exchange with the blood vessel wall promotes cerebral amyloid angiopathy in an animal model of Alzheimer's disease. The Journal of neuroscience : the official journal of the Society for Neuroscience 24:3453-3459.

Fuentealba RA, Liu Q, Zhang J, Kanekiyo T, Hu X, Lee JM, LaDu MJ, Bu G (2010) Lowdensity lipoprotein receptor-related protein 1 (LRP1) mediates neuronal Abeta42 uptake and lysosomal trafficking. PLoS One 5:e11884.

Fujii G, Chang JE, Coley T, Steere B (1997) The formation of amphotericin B ion channels in lipid bilayers. Biochemistry 36:4959-4968.

Fulop L, Zarandi M, Datki Z, Soos K, Penke B (2004) Beta-amyloid-derived pentapeptide RIIGLa inhibits Abeta(1-42) aggregation and toxicity. Biochem Biophys Res Commun 324:64-69. 
Gao S, Hendrie HC, Hall KS, Hui S (1998) The relationships between age, sex, and the incidence of dementia and Alzheimer disease: a meta-analysis. Archives of general psychiatry 55:809-815.

Gaugler MN, Genc O, Bobela W, Mohanna S, Ardah MT, El-Agnaf OM, Cantoni M, Bensadoun JC, Schneggenburger R, Knott GW, Aebischer P, Schneider BL (2012) Nigrostriatal overabundance of alpha-synuclein leads to decreased vesicle density and deficits in dopamine release that correlate with reduced motor activity. Acta Neuropathol 123:653-669.

Geddes JW (2005) alpha-Synuclein: a potent inducer of tau pathology. Experimental neurology 192:244-250.

Giasson BI, Forman MS, Higuchi M, Golbe LI, Graves CL, Kotzbauer PT, Trojanowski JQ, Lee VM (2003) Initiation and synergistic fibrillization of tau and alpha-synuclein. Science 300:636-640.

Goedert M, Crowther RA (1989) Amyloid plaques, neurofibrillary tangles and their relevance for the study of Alzheimer's disease. Neurobiol Aging 10:405-406; discussion 412404.

Goldgaber D, Lerman MI, McBride OW, Saffiotti U, Gajdusek DC (1987) Characterization and chromosomal localization of a cDNA encoding brain amyloid of Alzheimer's disease. Science 235:877-880.

Gong Y, Chang L, Viola KL, Lacor PN, Lambert MP, Finch CE, Krafft GA, Klein WL (2003) Alzheimer's disease-affected brain: presence of oligomeric A beta ligands (ADDLs) suggests a molecular basis for reversible memory loss. Proceedings of the National Academy of Sciences of the United States of America 100:10417-10422.

Gosavi N, Lee HJ, Lee JS, Patel S, Lee SJ (2002) Golgi fragmentation occurs in the cells with prefibrillar alpha-synuclein aggregates and precedes the formation of fibrillar inclusion. The Journal of biological chemistry 277:48984-48992.

Gotz J, Schild A, Hoerndli F, Pennanen L (2004) Amyloid-induced neurofibrillary tangle formation in Alzheimer's disease: insight from transgenic mouse and tissue-culture models. Int J Dev Neurosci 22:453-465.

Gowing E, Roher AE, Woods AS, Cotter RJ, Chaney M, Little SP, Ball MJ (1994) Chemical characterization of A beta 17-42 peptide, a component of diffuse amyloid deposits of Alzheimer disease. The Journal of biological chemistry 269:10987-10990.

Grundke-Iqbal I, Iqbal K, Tung YC, Quinlan M, Wisniewski HM, Binder LI (1986) Abnormal phosphorylation of the microtubule-associated protein tau (tau) in Alzheimer cytoskeletal pathology. Proceedings of the National Academy of Sciences of the United States of America 83:4913-4917.

Guo Q, Wang Z, Li H, Wiese M, Zheng H (2011) APP physiological and pathophysiological functions: insights from animal models. Cell Res.

Hardy J, Allsop D (1991) Amyloid deposition as the central event in the aetiology of Alzheimer's disease. Trends in pharmacological sciences 12:383-388.

Hardy J, Selkoe DJ (2002) The amyloid hypothesis of Alzheimer's disease: progress and problems on the road to therapeutics. Science 297:353-356.

Hasegawa M, Fujiwara H, Nonaka T, Wakabayashi K, Takahashi H, Lee VM, Trojanowski JQ, Mann D, Iwatsubo T (2002) Phosphorylated alpha-synuclein is ubiquitinated in alpha-synucleinopathy lesions. The Journal of biological chemistry 277:49071-49076. 
Hepler RW, Grimm KM, Nahas DD, Breese R, Dodson EC, Acton P, Keller PM, Yeager M, Wang H, Shughrue P, Kinney G, Joyce JG (2006) Solution state characterization of amyloid beta-derived diffusible ligands. Biochemistry 45:15157-15167.

Howell GA, Welch MG, Frederickson CJ (1984) Stimulation-induced uptake and release of zinc in hippocampal slices. Nature 308:736-738.

Hung LW, Ciccotosto GD, Giannakis E, Tew DJ, Perez K, Masters CL, Cappai R, Wade JD, Barnham KJ (2008) Amyloid-beta peptide (Abeta) neurotoxicity is modulated by the rate of peptide aggregation: Abeta dimers and trimers correlate with neurotoxicity. The Journal of neuroscience : the official journal of the Society for Neuroscience 28:11950-11958.

Iqbal K, Alonso Adel C, Chen S, Chohan MO, El-Akkad E, Gong CX, Khatoon S, Li B, Liu F, Rahman A, Tanimukai H, Grundke-Iqbal I (2005) Tau pathology in Alzheimer disease and other tauopathies. Biochimica et biophysica acta 1739:198-210.

Iwai A, Yoshimoto M, Masliah E, Saitoh T (1995) Non-A beta component of Alzheimer's disease amyloid (NAC) is amyloidogenic. Biochemistry 34:10139-10145.

Iwatsubo T, Mann DM, Odaka A, Suzuki N, Ihara Y (1995) Amyloid beta protein (A beta) deposition: A beta 42(43) precedes A beta 40 in Down syndrome. Annals of neurology 37:294-299.

Iwatsubo T, Odaka A, Suzuki N, Mizusawa H, Nukina N, Ihara Y (1994) Visualization of A beta 42(43) and A beta 40 in senile plaques with end-specific A beta monoclonals: evidence that an initially deposited species is A beta 42(43). Neuron 13:45-53.

Jarrett JT, Berger EP, Lansbury PT, Jr. (1993) The carboxy terminus of the beta amyloid protein is critical for the seeding of amyloid formation: implications for the pathogenesis of Alzheimer's disease. Biochemistry 32:4693-4697.

Jenkins EC, Devine-Gage EA, Robakis NK, Yao XL, Brown WT, Houck GE, Jr., Wolfe G, Ramakrishna N, Silverman WP, Wisniewski HM (1988) Fine mapping of an Alzheimer disease-associated gene encoding beta-amyloid protein. Biochem Biophys Res Commun 151:1-8.

Jensen PH, Nielsen MS, Jakes R, Dotti CG, Goedert M (1998) Binding of alpha-synuclein to brain vesicles is abolished by familial Parkinson's disease mutation. The Journal of biological chemistry 273:26292-26294.

Joachim CL, Morris JH, Selkoe DJ (1989) Diffuse senile plaques occur commonly in the cerebellum in Alzheimer's disease. The American journal of pathology 135:309-319.

Kanekiyo T, Bu G (2009) Receptor-associated protein interacts with amyloid-beta peptide and promotes its cellular uptake. The Journal of biological chemistry 284:33352-33359.

Kang J, Lemaire HG, Unterbeck A, Salbaum JM, Masters CL, Grzeschik KH, Multhaup G, Beyreuther K, Muller-Hill B (1987) The precursor of Alzheimer's disease amyloid A4 protein resembles a cell-surface receptor. Nature 325:733-736.

Kay AR (2003) Evidence for chelatable zinc in the extracellular space of the hippocampus, but little evidence for synaptic release of $\mathrm{Zn}$. The Journal of neuroscience : the official journal of the Society for Neuroscience 23:6847-6855.

Kayed R, Glabe CG (2006) Conformation-dependent anti-amyloid oligomer antibodies. Methods in enzymology 413:326-344.

Koh JY, Suh SW, Gwag BJ, He YY, Hsu CY, Choi DW (1996) The role of zinc in selective neuronal death after transient global cerebral ischemia. Science 272:1013-1016.

Korenberg JR, Pulst SM, Neve RL, West R (1989) The Alzheimer amyloid precursor protein maps to human chromosome 21 bands q21.105-q21.05. Genomics 5:124-127. 
Kruger R, Vieira-Saecker AM, Kuhn W, Berg D, Muller T, Kuhnl N, Fuchs GA, Storch A, Hungs M, Woitalla D, Przuntek H, Epplen JT, Schols L, Riess O (1999) Increased susceptibility to sporadic Parkinson's disease by a certain combined alphasynuclein/apolipoprotein E genotype. Annals of neurology 45:611-617.

Kumar B, Nahreini P, Hanson AJ, Andreatta C, Prasad JE, Prasad KN (2005) Selenomethionine prevents degeneration induced by overexpression of wild-type human alpha-synuclein during differentiation of neuroblastoma cells. Journal of the American College of Nutrition 24:516-523.

Kuwahara T, Tonegawa R, Ito G, Mitani S, Iwatsubo T (2012) Phosphorylation of alphasynuclein protein at Ser-129 reduces neuronal dysfunction by lowering its membrane binding property in Caenorhabditis elegans. The Journal of biological chemistry 287:7098-7109.

Laemmli UK (1970) Cleavage of structural proteins during the assembly of the head of bacteriophage T4. Nature 227:680-685.

Lambert MP, Stevens G, Sabo S, Barber K, Wang G, Wade W, Krafft G, Snyder S, Holzman TF, Klein WL (1994) Beta/A4-evoked degeneration of differentiated SH-SY5Y human neuroblastoma cells. J Neurosci Res 39:377-385.

Lambert MP, Viola KL, Chromy BA, Chang L, Morgan TE, Yu J, Venton DL, Krafft GA, Finch CE, Klein WL (2001) Vaccination with soluble Abeta oligomers generates toxicity-neutralizing antibodies. Journal of neurochemistry 79:595-605.

Lannfelt L, Blennow K, Zetterberg H, Batsman S, Ames D, Harrison J, Masters CL, Targum S, Bush AI, Murdoch R, Wilson J, Ritchie CW (2008) Safety, efficacy, and biomarker findings of PBT2 in targeting Abeta as a modifying therapy for Alzheimer's disease: a phase IIa, double-blind, randomised, placebo-controlled trial. Lancet neurology 7:779786.

Law W, Kelland EE, Sharp P, Toms NJ (2003) Characterisation of zinc uptake into rat cultured cerebrocortical oligodendrocyte progenitor cells. Neurosci Lett 352:113-116.

Lazarov O, Lee M, Peterson DA, Sisodia SS (2002) Evidence that synaptically released betaamyloid accumulates as extracellular deposits in the hippocampus of transgenic mice. The Journal of neuroscience : the official journal of the Society for Neuroscience 22:9785-9793.

Lee HJ, Khoshaghideh F, Lee S, Lee SJ (2006) Impairment of microtubule-dependent trafficking by overexpression of alpha-synuclein. Eur J Neurosci 24:3153-3162.

Lee JY, Cole TB, Palmiter RD, Suh SW, Koh JY (2002) Contribution by synaptic zinc to the gender-disparate plaque formation in human Swedish mutant APP transgenic mice. Proceedings of the National Academy of Sciences of the United States of America 99:7705-7710.

Lee JY, Kim JH, Hong SH, Cherny RA, Bush AI, Palmiter RD, Koh JY (2004) Estrogen decreases zinc transporter 3 expression and synaptic vesicle zinc levels in mouse brain. The Journal of biological chemistry 279:8602-8607.

Lee JY, Mook-Jung I, Koh JY (1999) Histochemically reactive zinc in plaques of the Swedish mutant beta-amyloid precursor protein transgenic mice. The Journal of neuroscience : the official journal of the Society for Neuroscience 19:RC10.

Lemere CA, Blusztajn JK, Yamaguchi H, Wisniewski T, Saido TC, Selkoe DJ (1996) Sequence of deposition of heterogeneous amyloid beta-peptides and APO E in Down syndrome: implications for initial events in amyloid plaque formation. Neurobiol Dis 3:16-32. 
LeVine H, 3rd (2002) 4,4(')-Dianilino-1,1(')-binaphthyl-5,5(')-disulfonate: report on non-betasheet conformers of Alzheimer's peptide beta(1-40). Archives of biochemistry and biophysics 404:106-115.

Lewis KA, Su Y, Jou O, Ritchie C, Foong C, Hynan LS, White CL, 3rd, Thomas PJ, Hatanpaa KJ (2010) Abnormal neurites containing C-terminally truncated alphasynuclein are present in Alzheimer's disease without conventional Lewy body pathology. The American journal of pathology 177:3037-3050.

Li Y, Hough CJ, Frederickson CJ, Sarvey JM (2001) Induction of mossy fiber --> Ca3 longterm potentiation requires translocation of synaptically released $\mathrm{Zn} 2+$. The Journal of neuroscience : the official journal of the Society for Neuroscience 21:8015-8025.

Lipton P, Aitken PG, Dudek FE, Eskessen K, Espanol MT, Ferchmin PA, Kelly JB, Kreisman NR, Landfield PW, Larkman PM, et al. (1995) Making the best of brain slices: comparing preparative methods. Journal of neuroscience methods 59:151-156.

Liu ST, Howlett G, Barrow CJ (1999) Histidine-13 is a crucial residue in the zinc ion-induced aggregation of the A beta peptide of Alzheimer's disease. Biochemistry 38:9373-9378.

Liu Y, Peterson DA, Kimura H, Schubert D (1997) Mechanism of cellular 3-(4,5dimethylthiazol-2-yl)-2,5-diphenyltetrazolium bromide (MTT) reduction. Journal of neurochemistry 69:581-593.

Liuzzi JP, Cousins RJ (2004) Mammalian zinc transporters. Annu Rev Nutr 24:151-172.

Lovell MA, Robertson JD, Teesdale WJ, Campbell JL, Markesbery WR (1998) Copper, iron and zinc in Alzheimer's disease senile plaques. Journal of the neurological sciences 158:47-52.

Lu YM, Taverna FA, Tu R, Ackerley CA, Wang YT, Roder J (2000) Endogenous Zn(2+) is required for the induction of long-term potentiation at rat hippocampal mossy fiberCA3 synapses. Synapse 38:187-197.

Mamah CE, Lesnick TG, Lincoln SJ, Strain KJ, de Andrade M, Bower JH, Ahlskog JE, Rocca WA, Farrer MJ, Maraganore DM (2005) Interaction of alpha-synuclein and tau genotypes in Parkinson's disease. Annals of neurology 57:439-443.

Manning-Bog AB, McCormack AL, Purisai MG, Bolin LM, Di Monte DA (2003) Alphasynuclein overexpression protects against paraquat-induced neurodegeneration. The Journal of neuroscience : the official journal of the Society for Neuroscience 23:30953099.

Maroteaux L, Campanelli JT, Scheller RH (1988) Synuclein: a neuron-specific protein localized to the nucleus and presynaptic nerve terminal. The Journal of neuroscience : the official journal of the Society for Neuroscience 8:2804-2815.

Mattson MP (2004) Pathways towards and away from Alzheimer's disease. Nature 430:631639.

Mattson MP (2006) Neuronal life-and-death signaling, apoptosis, and neurodegenerative disorders. Antioxidants \& redox signaling 8:1997-2006.

Mattson MP, Zhang Y, Bose S (1993) Growth factors prevent mitochondrial dysfunction, loss of calcium homeostasis, and cell injury, but not ATP depletion in hippocampal neurons deprived of glucose. Experimental neurology 121:1-13.

Maynard CJ, Cappai R, Volitakis I, Cherny RA, Masters CL, Li QX, Bush AI (2006) Gender and genetic background effects on brain metal levels in APP transgenic and normal mice: implications for Alzheimer beta-amyloid pathology. Journal of inorganic biochemistry 100:952-962. 
Metcalfe MJ, Figueiredo-Pereira ME (2010) Relationship between tau pathology and neuroinflammation in Alzheimer's disease. Mt Sinai J Med 77:50-58.

Miller LM, Wang Q, Telivala TP, Smith RJ, Lanzirotti A, Miklossy J (2006) Synchrotronbased infrared and X-ray imaging shows focalized accumulation of $\mathrm{Cu}$ and $\mathrm{Zn}$ colocalized with beta-amyloid deposits in Alzheimer's disease. Journal of structural biology 155:30-37.

Mocchegiani E, Bertoni-Freddari C, Marcellini F, Malavolta M (2005) Brain, aging and neurodegeneration: role of zinc ion availability. Prog Neurobiol 75:367-390.

Noguchi A, Matsumura S, Dezawa M, Tada M, Yanazawa M, Ito A, Akioka M, Kikuchi S, Sato M, Ideno S, Noda M, Fukunari A, Muramatsu S, Itokazu Y, Sato K, Takahashi H, Teplow DB, Nabeshima Y, Kakita A, Imahori K, Hoshi M (2009) Isolation and characterization of patient-derived, toxic, high mass amyloid beta-protein (Abeta) assembly from Alzheimer disease brains. The Journal of biological chemistry 284:32895-32905.

Nukina N, Ihara Y (1986) One of the antigenic determinants of paired helical filaments is related to tau protein. J Biochem 99:1541-1544.

Obulesu M, Rao DM (2010) DNA damage and impairment of DNA repair in Alzheimer's disease. Int J Neurosci 120:397-403.

Opazo C, Huang X, Cherny RA, Moir RD, Roher AE, White AR, Cappai R, Masters CL, Tanzi RE, Inestrosa NC, Bush AI (2002) Metalloenzyme-like activity of Alzheimer's disease beta-amyloid. Cu-dependent catalytic conversion of dopamine, cholesterol, and biological reducing agents to neurotoxic $\mathrm{H}(2) \mathrm{O}(2)$. The Journal of biological chemistry 277:40302-40308.

Ostrerova N, Petrucelli L, Farrer M, Mehta N, Choi P, Hardy J, Wolozin B (1999) alphaSynuclein shares physical and functional homology with 14-3-3 proteins. The Journal of neuroscience : the official journal of the Society for Neuroscience 19:5782-5791.

Outeiro TF, Lindquist S (2003) Yeast cells provide insight into alpha-synuclein biology and pathobiology. Science 302:1772-1775.

Palmiter RD, Cole TB, Quaife CJ, Findley SD (1996) ZnT-3, a putative transporter of zinc into synaptic vesicles. Proceedings of the National Academy of Sciences of the United States of America 93:14934-14939.

Parkin G (2004) Chemistry. Zinc-zinc bonds: a new frontier. Science 305:1117-1118.

Patterson D, Gardiner K, Kao FT, Tanzi R, Watkins P, Gusella JF (1988) Mapping of the gene encoding the beta-amyloid precursor protein and its relationship to the Down syndrome region of chromosome 21. Proceedings of the National Academy of Sciences of the United States of America 85:8266-8270.

Petralia RS, Wang YX, Wenthold RJ (1994) The NMDA receptor subunits NR2A and NR2B show histological and ultrastructural localization patterns similar to those of NR1. The Journal of neuroscience : the official journal of the Society for Neuroscience 14:61026120.

Pirev E, Ince Y, Sies H, Kroncke KD (2010) Heat shock but not cold shock leads to disturbed intracellular zinc homeostasis. Journal of cellular physiology 223:103-109.

Pletnikova O, West N, Lee MK, Rudow GL, Skolasky RL, Dawson TM, Marsh L, Troncoso JC (2005) Abeta deposition is associated with enhanced cortical alpha-synuclein lesions in Lewy body diseases. Neurobiol Aging 26:1183-1192.

Polymeropoulos MH, Lavedan C, Leroy E, Ide SE, Dehejia A, Dutra A, Pike B, Root H, Rubenstein J, Boyer R, Stenroos ES, Chandrasekharappa S, Athanassiadou A, 
Papapetropoulos T, Johnson WG, Lazzarini AM, Duvoisin RC, Di Iorio G, Golbe LI, Nussbaum RL (1997) Mutation in the alpha-synuclein gene identified in families with Parkinson's disease. Science 276:2045-2047.

Presgraves SP, Ahmed T, Borwege S, Joyce JN (2004) Terminally differentiated SH-SY5Y cells provide a model system for studying neuroprotective effects of dopamine agonists. Neurotox Res 5:579-598.

Qian J, Noebels JL (2005) Visualization of transmitter release with zinc fluorescence detection at the mouse hippocampal mossy fibre synapse. The Journal of physiology 566:747-758.

Qian J, Noebels JL (2006) Exocytosis of vesicular zinc reveals persistent depression of neurotransmitter release during metabotropic glutamate receptor long-term depression at the hippocampal CA3-CA1 synapse. The Journal of neuroscience : the official journal of the Society for Neuroscience 26:6089-6095.

Rebar EJ, Pabo CO (1994) Zinc finger phage: affinity selection of fingers with new DNAbinding specificities. Science 263:671-673.

Robakis NK, Ramakrishna N, Wolfe G, Wisniewski HM (1987) Molecular cloning and characterization of a cDNA encoding the cerebrovascular and the neuritic plaque amyloid peptides. Proceedings of the National Academy of Sciences of the United States of America 84:4190-4194.

Rui Y, Tiwari P, Xie Z, Zheng JQ (2006) Acute impairment of mitochondrial trafficking by beta-amyloid peptides in hippocampal neurons. The Journal of neuroscience : the official journal of the Society for Neuroscience 26:10480-10487.

Schlief ML, Craig AM, Gitlin JD (2005) NMDA receptor activation mediates copper homeostasis in hippocampal neurons. The Journal of neuroscience : the official journal of the Society for Neuroscience 25:239-246.

Schuck P (2000) Size-distribution analysis of macromolecules by sedimentation velocity ultracentrifugation and lamm equation modeling. Biophys J 78:1606-1619.

Selkoe DJ (2003) Folding proteins in fatal ways. Nature 426:900-904.

Sensi SL, Paoletti P, Bush AI, Sekler I (2009) Zinc in the physiology and pathology of the CNS. Nature reviews Neuroscience 10:780-791.

Seve M, Chimienti F, Devergnas S, Favier A (2004) In silico identification and expression of SLC30 family genes: an expressed sequence tag data mining strategy for the characterization of zinc transporters' tissue expression. BMC Genomics 5:32.

Shibayama-Imazu T, Okahashi I, Omata K, Nakajo S, Ochiai H, Nakai Y, Hama T, Nakamura Y, Nakaya K (1993) Cell and tissue distribution and developmental change of neuron specific $14 \mathrm{kDa}$ protein (phosphoneuroprotein 14). Brain Res 622:17-25.

Shigenaga MK, Hagen TM, Ames BN (1994) Oxidative damage and mitochondrial decay in aging. Proceedings of the National Academy of Sciences of the United States of America 91:10771-10778.

Shimura H, Schlossmacher MG, Hattori N, Frosch MP, Trockenbacher A, Schneider R, Mizuno Y, Kosik KS, Selkoe DJ (2001) Ubiquitination of a new form of alphasynuclein by parkin from human brain: implications for Parkinson's disease. Science 293:263-269.

Smidt K, Jessen N, Petersen AB, Larsen A, Magnusson N, Jeppesen JB, Stoltenberg M, Culvenor JG, Tsatsanis A, Brock B, Schmitz O, Wogensen L, Bush AI, Rungby J (2009) SLC30A3 responds to glucose- and zinc variations in beta-cells and is critical 
for insulin production and in vivo glucose-metabolism during beta-cell stress. PLoS One 4:e5684.

Smith DG, Cappai R, Barnham KJ (2007) The redox chemistry of the Alzheimer's disease amyloid beta peptide. Biochimica et biophysica acta 1768:1976-1990.

Song DD, Shults CW, Sisk A, Rockenstein E, Masliah E (2004) Enhanced substantia nigra mitochondrial pathology in human alpha-synuclein transgenic mice after treatment with MPTP. Experimental neurology 186:158-172.

Spillantini MG, Crowther RA, Jakes R, Hasegawa M, Goedert M (1998) alpha-Synuclein in filamentous inclusions of Lewy bodies from Parkinson's disease and dementia with lewy bodies. Proceedings of the National Academy of Sciences of the United States of America 95:6469-6473.

Stoltenberg M, Bush AI, Bach G, Smidt K, Larsen A, Rungby J, Lund S, Doering P, Danscher G (2007) Amyloid plaques arise from zinc-enriched cortical layers in APP/PS1 transgenic mice and are paradoxically enlarged with dietary zinc deficiency. Neuroscience 150:357-369.

Suh SW, Won SJ, Hamby AM, Yoo BH, Fan Y, Sheline CT, Tamano H, Takeda A, Liu J (2009) Decreased brain zinc availability reduces hippocampal neurogenesis in mice and rats. Journal of cerebral blood flow and metabolism : official journal of the International Society of Cerebral Blood Flow and Metabolism 29:1579-1588.

Tagliavini F, Giaccone G, Bugiani O, Frangione B (1993) Ubiquitinated neurites are associated with preamyloid and cerebral amyloid beta deposits in patients with hereditary cerebral hemorrhage with amyloidosis Dutch type. Acta Neuropathol 85:267-271.

Tagliavini F, Giaccone G, Frangione B, Bugiani O (1988) Preamyloid deposits in the cerebral cortex of patients with Alzheimer's disease and nondemented individuals. Neurosci Lett 93:191-196.

Takeda A, Tamano H (2009) Insight into zinc signaling from dietary zinc deficiency. Brain research reviews 62:33-44.

Thayanidhi N, Helm JR, Nycz DC, Bentley M, Liang Y, Hay JC (2010) Alpha-synuclein delays endoplasmic reticulum (ER)-to-Golgi transport in mammalian cells by antagonizing ER/Golgi SNAREs. Mol Biol Cell 21:1850-1863.

Ueda K, Fukushima H, Masliah E, Xia Y, Iwai A, Yoshimoto M, Otero DA, Kondo J, Ihara Y, Saitoh T (1993) Molecular cloning of cDNA encoding an unrecognized component of amyloid in Alzheimer disease. Proceedings of the National Academy of Sciences of the United States of America 90:11282-11286.

Varlam DE, Siddiq MM, Parton LA, Russmann H (2001) Apoptosis contributes to amphotericin B-induced nephrotoxicity. Antimicrobial agents and chemotherapy 45:679-685.

Vartiainen S, Aarnio V, Lakso M, Wong G (2006) Increased lifespan in transgenic Caenorhabditis elegans overexpressing human alpha-synuclein. Exp Gerontol 41:871876.

Walsh DM, Klyubin I, Fadeeva JV, Cullen WK, Anwyl R, Wolfe MS, Rowan MJ, Selkoe DJ (2002) Naturally secreted oligomers of amyloid beta protein potently inhibit hippocampal long-term potentiation in vivo. Nature 416:535-539.

Wang Z, Li JY, Dahlstrom A, Danscher G (2001) Zinc-enriched GABAergic terminals in mouse spinal cord. Brain Res 921:165-172. 
Williams RJP (1989) An Introduction to the Biochemistry of Zinc. In: Zinc in Human Biology(Mills, C. F., ed), pp 15-31 London: Springer-Verlag.

Winner B, Lie DC, Rockenstein E, Aigner R, Aigner L, Masliah E, Kuhn HG, Winkler J (2004) Human wild-type alpha-synuclein impairs neurogenesis. J Neuropathol Exp Neurol 63:1155-1166.

Yamaguchi H, Hirai S, Morimatsu M, Shoji M, Harigaya Y (1988) Diffuse type of senile plaques in the brains of Alzheimer-type dementia. Acta Neuropathol 77:113-119.

Yoshimoto M, Iwai A, Kang D, Otero DA, Xia Y, Saitoh T (1995) NACP, the precursor protein of the non-amyloid beta/A4 protein (A beta) component of Alzheimer disease amyloid, binds A beta and stimulates A beta aggregation. Proceedings of the National Academy of Sciences of the United States of America 92:9141-9145.

Zarandi M, Soos K, Fulop L, Bozso Z, Datki Z, Toth GK, Penke B (2007) Synthesis of Abeta[1-42] and its derivatives with improved efficiency. J Pept Sci 13:94-99.

Zheng WH, Bastianetto S, Mennicken F, Ma W, Kar S (2002) Amyloid beta peptide induces tau phosphorylation and loss of cholinergic neurons in rat primary septal cultures. Neuroscience 115:201-211. 